\title{
WATER-QUALITY ASSESSMENT OF THE RIO GRANDE VALLEY, COLORADO, NEW MEXICO, AND TEXAS-- Summary and analysis of water-quality data for the basic-fixed-site network, 1993-95
}

U.S. Department of the Interior

U.S. Geological Survey

Water-Resources Investigations Report 97-4212
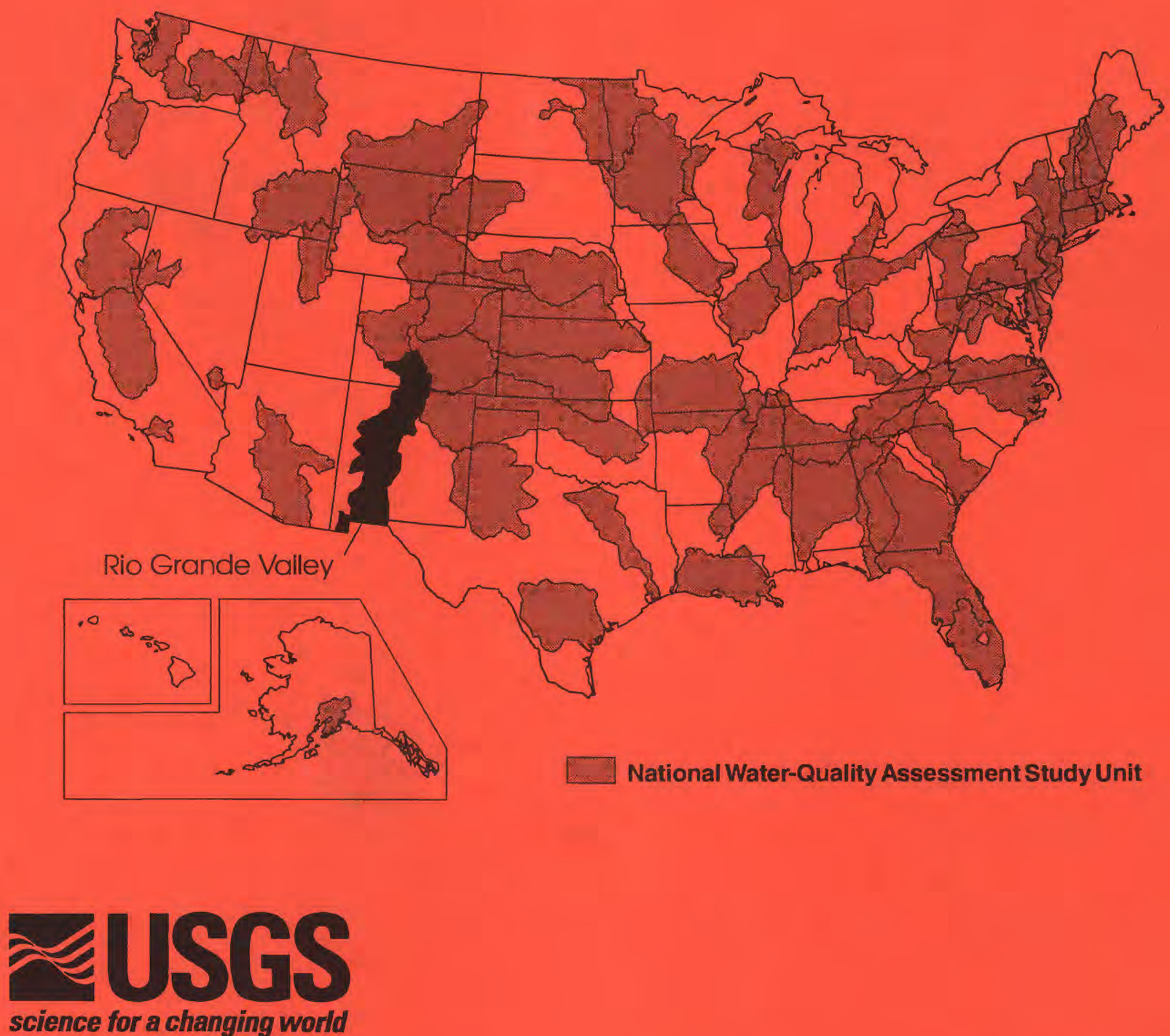

science for a changing world 


\section{WATER-QUALITY ASSESSMENT OF THE RIO GRANDE VALLEY, COLORADO, NEW MEXICO, AND TEXAS-- Summary and analysis of water-quality data for the basic-fixed-site network, 1993-95}

By Denis F. Healy

U.S. Department of the Interior

U.S. Geological Survey

Water-Resources Investigations Report 97-4212

Albuquerque, New Mexico

1997 


\section{U.S. DEPARTMENT OF THE INTERIOR \\ BRUCE BABBITT, Secretary}

U.S. GEOLOGICAL SURVEY

Mark Schaefer, Acting Director

Any use of firm, trade, or brand names in this report is for identification purposes

only and does not constitute endorsement by the U.S. Geological Survey.

For additional information write to:

Copies of this report can be purchased from:

District Chief

U.S. Geological Survey

Water Resources Division

4501 Indian School Road NE, Suite 200

Albuquerque, NM 87110-3929
U.S. Geological Survey

Branch of Information Services

Box 25286

Denver, CO 80225-0286

Information regarding the National Water-Quality Assessment (NAWQA) Program is available on the Internet via the World Wide Web. You may connect to the NAWQA Home Page using the Universal Resource Locator (URL) at:

$<$ http://wwwrvares.er.usgs.gov/nawqa/nawqa_home.html> 


\section{FOREWORD}

The mission of the U.S. Geological Survey (USGS) is to assess the quantity and quality of the earth resources of the Nation and to provide information that will assist resource managers and policymakers at Federal, State. and local levels in making sound decisions. Assessment of water-quality conditions and trends is an important part of this overall mission.

One of the greatest challenges faced by waterresources scientists is acquiring reliable information that will guide the use and protection of the Nation's water resources. That challenge is being addressed by Federal, State, interstate, and local water-resource agencies and by many academic institutions. These organizations are collecting water-quality data for a host of purposes that include: compliance with permits and water-supply standards; development of remediation plans for a specific contamination problem; operational decisions on industrial, wastewater, or watersupply facilities; and research on factors that affect water quality. An additional need for water-quality information is to provide a basis on which regional and national-level policy decisions can be based. Wise decisions must be based on sound information. As a society we need to know whether certain types of water-quality problems are isolated or ubiquitous, whether there are significant differences in conditions among regions, whether the conditions are changing over time, and why these conditions change from place to place and over time. The information can be used to help determine the efficacy of existing waterquality policies and to help analysts determine the need for and likely consequences of new policies.

To address these needs, the Congress appropriated funds in 1986 for the USGS to begin a pilot program in seven project areas to develop and refine the National Water-Quality Assessment (NAWQA) Program. In 1991, the USGS began full implementation of the program. The NAWQA Program builds upon an existing base of water-quality studies of the USGS, as well as those of other Federal, State, and local agencies. The objectives of the NAWQA Program are to:

- Describe current water-quality conditions for a large part of the Nation's freshwater streams, rivers, and aquifers.

-Describe how water quality is changing over time.

-Improve understanding of the primary natural and human factors that affect water-quality conditions.
This information will help support the development and evaluation of management, regulatory, and monitoring decisions by other Federal, State, and local agencies to protect, use, and enhance water resources.

The goals of the NAWQA Program are being achieved through ongoing and proposed investigations of 59 of the Nation's most important river basins and aquifer systems, which are referred to as study units. These study units are distributed throughout the Nation and cover a diversity of hydrogeologic settings. More than two-thirds of the Nation's freshwater use occurs within the 59 study units and more than two-thirds of the people served by public water-supply systems live within their boundaries.

National synthesis of data analysis, based on aggregation of comparable information obtained from the study units, is a major component of the program. This effort focuses on selected water-quality topics using nationally consistent information. Comparative studies will explain differences and similarities in observed water-quality conditions among study areas and will identify changes and trends and their causes. The first topics addressed by the national synthesis are pesticides, nutrients, volatile organic compounds, and aquatic biology. Discussions on these and other waterquality topics will be published in periodic summaries of the quality of the Nation's ground and surface water as the information becomes available.

This report is an element of the comprehensive body of information developed as part of the NAWQA Program. The program depends heavily on the advice, cooperation, and information from many Federal, State, interstate, Tribal, and local agencies and the public. The assistance and suggestions of all are greatly appreciated. 


\section{CONTENTS}

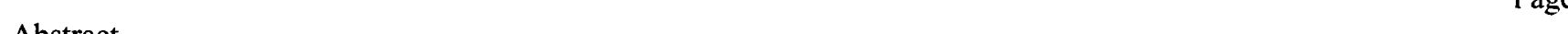

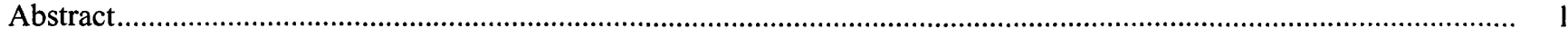

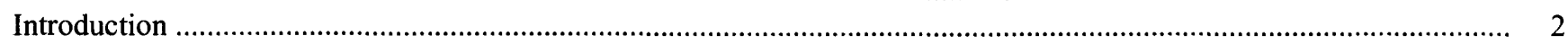

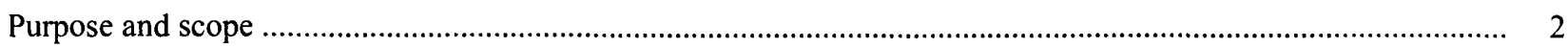

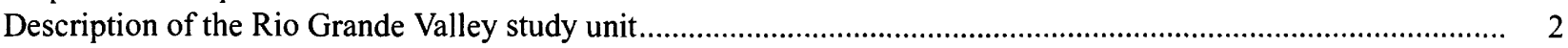

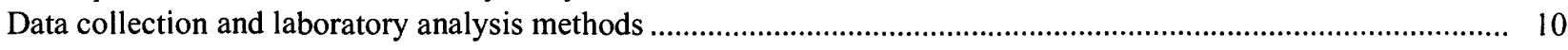

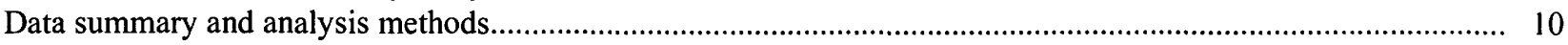

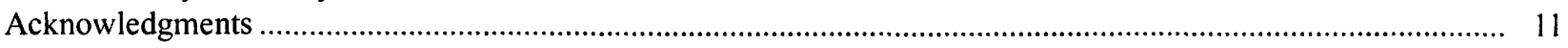

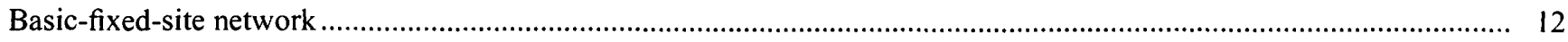

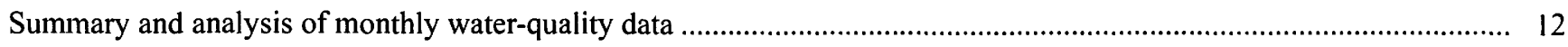

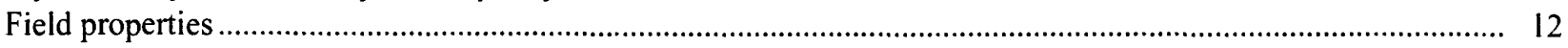

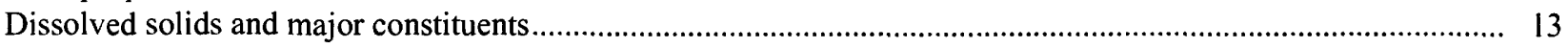

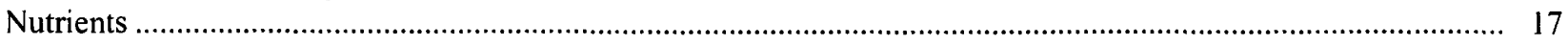

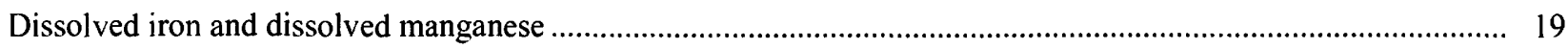

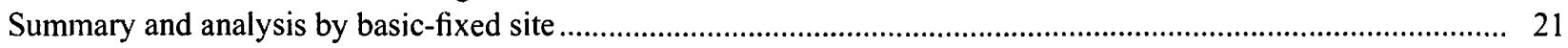

Site 1 - Rio Grande near Del Norte, Colo....................................................................................... 21

Site 2 - Saguache Creek near Saguache, Colo.................................................................................... 22

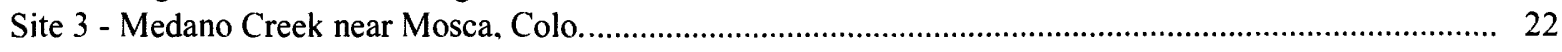

Site 4 - Rio Grande above mouth of Trinchera Creek, near Lasauses, Colo. ....................................... 27

Site 5 - Conejos River near Lasauses, Colo.................................................................................... 30

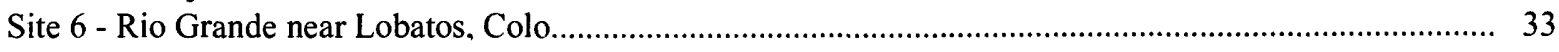

Site 7 - Rio Grande below Taos Junction Bridge, near Taos, N. Mex.................................................... 36

Site 8 - Rio Chama near Chamita, N. Mex..................................................................................... 39

Site 9 - Rio Grande at Otowi Bridge, near San Ildefonso, N. Mex. ....................................................... 42

Site 10 - Rito de los Frijoles in Bandelier National Monument, N. Mex............................................... 42

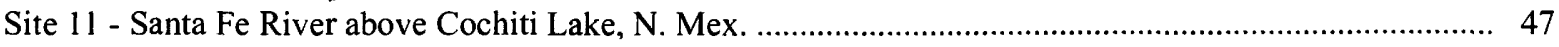

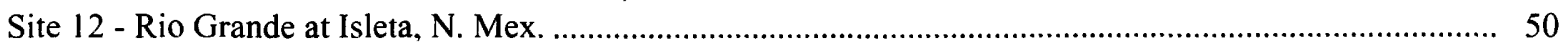

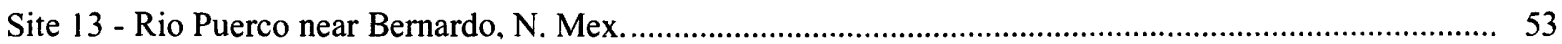

Site 14 - Rio Grande Conveyance Channel at San Marcial, N. Mex. .................................................... 56

Site 15 - Rio Grande Floodway at San Marcial, N. Mex................................................................. 59

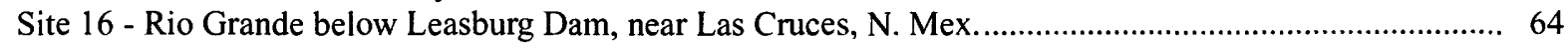

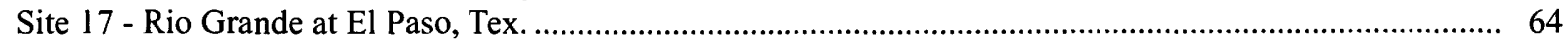

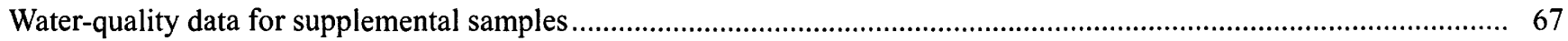

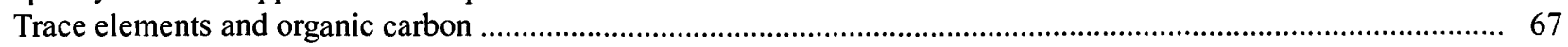

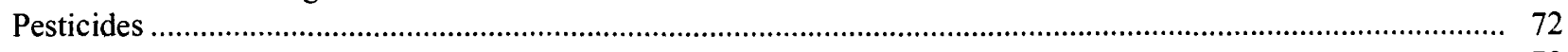

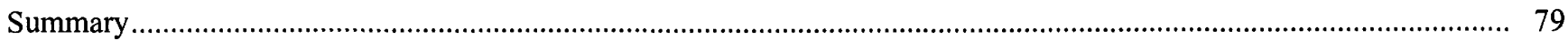

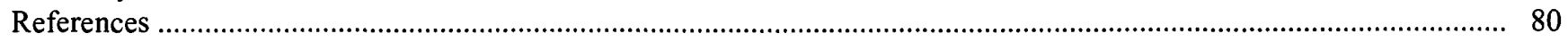

\section{FIGURES}

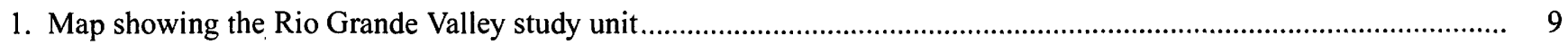

2. Box plots showing dissolved-solids and major-constituent concentrations detected at basic-fixed sites ...................... 14

3. Map showing median dissolved-solids concentrations and major-constituent ratios at basic-fixed sites ....................... 16

4. Box plots showing nutrient concentrations detected at basic-fixed sites................................................................ 18

5. Map showing median dissolved nitrite plus nitrate concentrations detected at basic-fixed sites............................... 20 
1. Rio Grande Valley basic-fixed-network sites

2. Streamflow, physical properties, and water-quality analytes sampled monthly

3. Supplemental trace-element and organic-carbon analytes

4. Supplemental pesticide and metabolite analytes

5. Statistical summary of selected water-quality data for site 1 - Rio Grande near Del Norte, Colo.

6. Regression equations for selected water-quality analytes with selected field properties and time for site 1 - Rio Grande near Del Norte, Colo

7. Statistical summary of selected water-quality data for site 2 - Saguache Creek near Saguache, Colo.

8. Regression equations for selected water-quality analytes with selected field properties and time for site 2 - Saguache Creek near Saguache, Colo.

9. Statistical summary of selected water-quality data for site 3 - Medano Creek near Mosca, Colo.

10. Regression equations for selected water-quality analytes with selected field properties and time for site 3 - Medano Creek near Mosca, Colo.

11. Statistical summary of selected water-quality data for site 4 - Rio Grande above mouth of Trinchera Creek, near Lasauses. Colo.

12. Regression equations for selected water-quality analytes with selected field properties and time for

site 4 - Rio Grande above mouth of Trinchera Creek, near Lasauses, Colo.

13. Statistical summary of selected water-quality data for site 5 - Conejos River near Lasauses, Colo.

14. Regression equations for selected water-quality analytes with selected field properties and time for site 5 - Conejos River near Lasauses, Colo.

15. Statistical summary of selected water-quality data for site 6 - Rio Grande near Lobatos, Colo. ........

16. Regression equations for selected water-quality analytes with selected field properties and time for site 6 - Rio Grande near Lobatos, Colo.

17. Statistical summary of selected water-quality data for site 7 - Rio Grande below Taos Junction Bridge, near Taos, N. Mex.

18. Regression equations for selected water-quality analytes with selected field properties and time for site 7 - Rio Grande below Taos Junction Bridge, near Taos, N. Mex.

19. Statistical summary of selected water-quality data for site 8 - Rio Chama near Chamita, N. Mex.

20. Regression equations for selected water-quality analytes with selected field properties and time for site 8 - Rio Chama near Chamita, N. Mex.

21. Statistical summary of selected water-quality data for site 9 - Rio Grande at Otowi Bridge, near San Ildefonso, N. Mex.

22. Regression equations for selected water-quality analytes with selected field properties and time for site 9 - Rio Grande at Otowi Bridge, near San Ildefonso, N. Mex.

23. Statistical summary of selected water-quality data for site 10 - Rito de los Frijoles in Bandelier National Monument, N. Mex.

24. Regression equations for selected water-quality analytes with selected field properties and time for site 10 - Rito de los Frijoles in Bandelier National Monument, N. Mex.

25. Statistical summary of selected water-quality data for site 11 - Santa Fe River above Cochiti Lake, N. Mex.

26. Regression equations for selected water-quality analytes with selected field properties and time for site 11 - Santa Fe River above Cochiti Lake, N. Mex.

27. Statistical summary of selected water-quality data for site 12 - Rio Grande at Isleta, N. Mex.

28. Regression equations for selected water-quality analytes with selected field properties and time for site 12 - Rio Grande at Isleta, N. Mex.

29. Statistical summary of selected water-quality data for site 13 - Rio Puerco near Bernardo, N. Mex.

30. Regression equations for selected water-quality analytes with selected field properties and time for site 13 - Rio Puerco near Bernardo, N. Mex.

31. Statistical summary of selected water-quality data for site 14 - Rio Grande Conveyance Channel at San Marcial, N. Mex.

32. Regression equations for selected water-quality analytes with selected field properties and time for site 14 - Rio Grande Conveyance Channel at San Marcial, N. Mex.

33. Statistical summary of selected water-quality data for site 15 - Rio Grande Floodway at San Marcial, N. Mex. 
34. Regression equations for selected water-quality analytes with selected field properties and time for site 15 - Rio Grande Floodway at San Marcial, N. Mex

35. Statistical summary of selected water-quality data for site 16 - Rio Grande below Leasburg Dam, near Las Cruces, N. Mex

36. Regression equations for selected water-quality analytes with selected field properties and time for site 16 - Rio Grande below Leasburg Dam, near Las Cruces, N. Mex

37. Statistical summary of selected water-quality data for site 17 - Rio Grande at El Paso, Tex

38. Regression equations for selected water-quality analytes with selected field properties and time for site 17 - Rio Grande at El Paso, Tex.

39. Summary statistics for supplemental trace-element analytes ........................................................................ 70

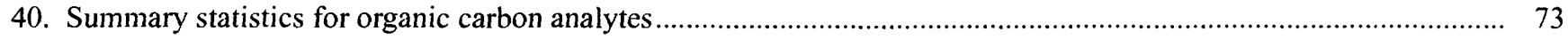

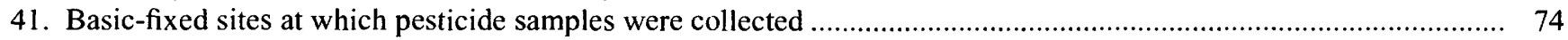

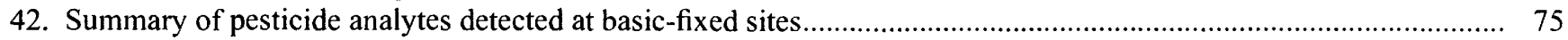

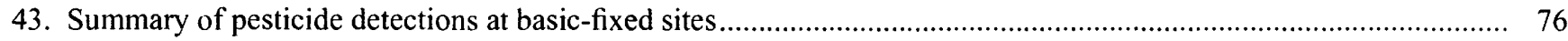

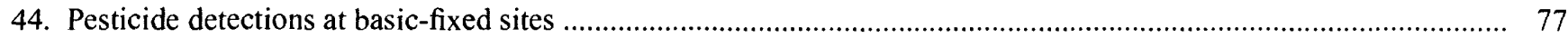




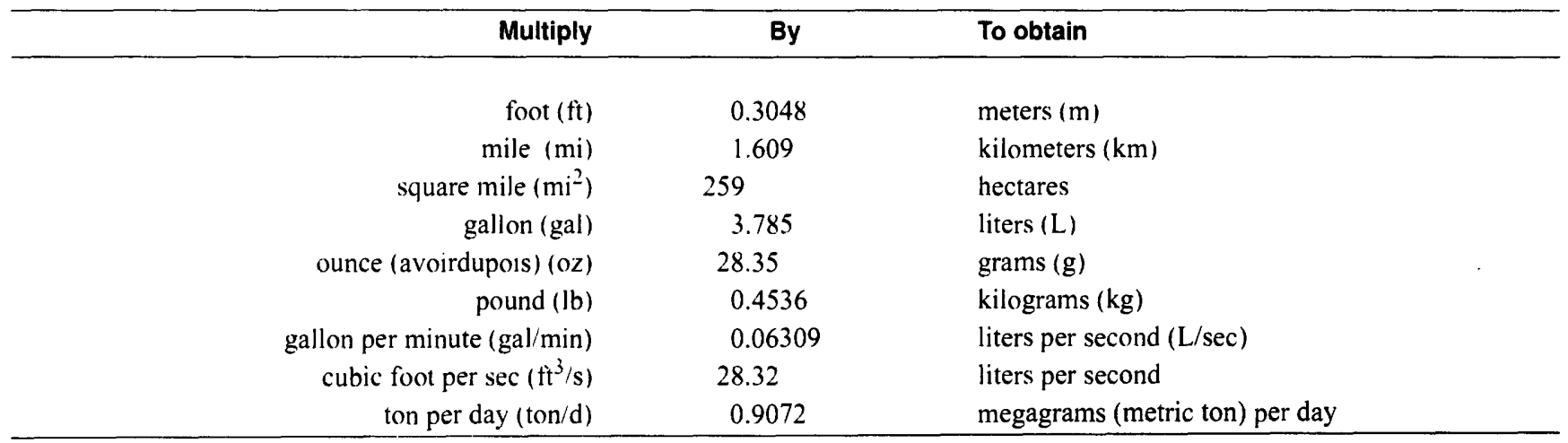

Milliequivalents per liter (meq/L) are equal to the concentration in milligrams per liter (mg/L) divided by the combining weight, which is the formula weight of that species divided by the charge (Hem, 1985).

Temperature in degrees Celsius $\left({ }^{\circ} \mathrm{C}\right)$ may be converted to degrees Fahrenheit $\left({ }^{\circ} \mathrm{F}\right)$ by the equation:

$$
{ }^{\circ} \mathrm{F}=9 / 5\left({ }^{\circ} \mathrm{C}\right)+32
$$

Sea level: In this report, "sea level" refers to the National Geodetic Vertical Datum of 1929-a geodetic datum derived from a general adjustment of the first-order level nets of the United States and Canada, formerly called Sea Level Datum of I 929. 


\title{
WATER-QUALITY ASSESSMENT OF THE RIO GRANDE VALLEY, COLORADO, NEW MEXICO, AND TEXAS -- SUMMARY AND ANALYSIS OF WATER-QUALITY DATA FOR THE BASIC-FIXED-SITE NETWORK, 1993-95
}

\author{
By Denis F. Healy
}

\section{Abstract}

The Rio Grande Valley study unit of the U.S. Geological Survey National Water-Quality Assessment Program collected monthly waterquality samples at a network of surface-water sites from April 1993 through September 1995. This basic-fixed-site network consisted of nine mainstem sites on the Rio Grande, five sites on tributaries of the Rio Grande, two sites on streams in the Rio Grande Valley study unit that are not directly tributary to the Rio Grande, and one site on a conveyance channel. During each monthly sampling, field properties were measured and samples were collected for the analysis of dissolved solids, major constituents, nutrients, selected trace elements, and suspended-sediment concentrations. During selected samplings, supplemental samples were collected for the analysis of additional trace elements, organic carbon, and/or pesticides.

Spatial variations of dissolved-solids, major-constituent, and nutrient data were analyzed. The report presents summary statistics for the monthly water-quality data by sampling site and background information on the drainage basin upstream from each site. Regression equations are presented that relate dissolvedsolids, major-constituent, and nutrient concentrations to streamflow, selected field properties, and time.

Median instantaneous streamflow at each basic-fixed site ranged from 1.4 to 1,380 cubic feet per second. Median specific conductance at each basic-fixed site ranged from 84 to 1,680 microsiemens per centimeter at 25 degrees Celsius, and median $\mathrm{pH}$ values ranged from 7.8 to 8.5. The water sampled at the basic-fixed sites generally was well oxygenated and had a median dissolved-oxygen percent of saturation range from 89 to 108 .

With the exception of Rio Grande above mouth of Trinchera Creek, near Lasauses, Colorado, dissolved-solids concentrations in the main stem of the Rio Grande generally increased in a downstream direction. This increase is from natural sources such as ground-water inflow and evapotranspiration and from anthropogenic sources such as irrigation-return flows, urban runoff, and wastewater-treatment plant discharges. The smallest median dissolved-solids concentration detected at a basic-fixed site was 58 milligrams per liter and the largest was 1,240 milligrams per liter.

The spatial distribution of calcium, magnesium, sodium, sulfate, chloride, and fluoride was similar to the spatial distribution of dissolved solids. The spatial distribution of potassium and bicarbonate varied slightly from that of dissolved solids. Median silica concentrations generally decreased in a downstream direction.

Of all cations, calcium and sodium had the largest concentrations at most basic-fixed sites. Bicarbonate and sulfate were the anions having the largest concentrations at most sites. The largest median silica concentration was at Rito de los Frijoles in Bandelier National Monument, New Mexico, where silica composed approximately 50 percent of the dissolved solids.

The largest concentrations and largest median concentrations of dissolved-nutrient analytes were detected at Santa Fe River above Cochiti Lake, New Mexico, and Rio Grande at Isleta, New Mexico. The relatively large dissolved-nutrient concentrations at these sites probably were due to discharges from wastewatertreatment plants and urban runoff. 
The largest concentrations and largest median concentrations of total ammonia plus organic nitrogen and total phosphorus were detected at Rio Puerco near Bernardo, New Mexico. The largest concentrations of these nutrients at this site were associated with runoff from summer thunderstorms.

Dissolved-iron concentrations ranged from censored concentrations to 914 micrograms per liter. Median dissolved-iron concentrations ranged from 3 to 160 micrograms per liter. Dissolvedmanganese concentrations ranged from censored concentrations to 300 micrograms per liter; median concentrations ranged from 1 to 68 micrograms per liter.

\section{INTRODUCTION}

The Rio Grande Valley assessment study (RIOG) began in 1991 as one of the first 20 study unit assessments of the National Water-Quality Assessment (NAWQA) Program of the U.S. Geological Survey (USGS) (Gilliom and others, 1995). RIOG personnel conducted a high-intensity sampling phase from September 1992 through September 1995. This phase included water-column and biological data collection at a network of surface-water sampling sites and surface-water, ground-water, and biological synoptic studies that ranged in size from single land-use studies to study unit assessments.

The surface-water sampling network is referred to as the basic-fixed-site network and was designed to provide an integrated assessment of the spatial and temporal distribution of general water-quality conditions and the transport of major inorganic constituents in streamwater in relation to hydrologic conditions and major sources (Gilliom and others, 1995). The RIOG basic-fixed-site network consists of 17 sites (table 1). Monthly sample collection was planned from April 1993 through September 1995, although the actual sampling schedule varied somewhat. During each monthly sampling streamflow, selected physical properties, and selected constituent concentrations (collectively hereafter referred to as field properties) were measured at the site and samples were collected for analysis of solids residue after evaporation at $180^{\circ} \mathrm{C}$ (hereafter referred to as dissolved solids) (DS), major constituents, nutrients, selected trace elements, and suspended sediment (table
2). During selected monthly samplings, supplemental samples also were collected for analysis of additional trace elements (table 3 ), organic carbon (table 3 ), and pesticides and metabolites (hereafter referred to as pesticides) (table 4). Supplemental samples include water-column samples collected at some network sites as part of the USGS National Surface-Water-Quality Accounting Network (NASQAN) Program (Ficke and Hawkinson, 1975), USGS New Mexico District cooperative programs (Livingston, 1995; U.S. Geological Survey, 1995), or specific RIOG synoptic studies (Anderholm, 1996; Healy, 1996; Bexfield and Anderholm, 1997; and Carter, 1997).

\section{Purpose and Scope}

This report presents summaries and analyses of water-quality data collected at sites in the basic-fixedsite network during the RIOG high-intensity sampling phase, including regression equations relating selected water-quality data to selected field properties and time. The report focuses on the field-property, DS, majorconstituent, nutrient. dissolved-iron, and dissolvedmanganese data collected at the network sites using NAWQA protocols (Shelton, 1994). Most of these data are for the monthly samples collected as part of the network sampling program. Additional data are for samples collected for NASQAN, New Mexico District cooperative programs, and RIOG synoptic studies. Water-quality data for the monthly samples are summarized and analyzed for the network and then examined for individual sites. This report presents only summaries of the supplemental trace-element, organic-carbon, and pesticide data.

\section{Description of the Rio Grande Valley Study Unit}

The RIOG study unit comprises approximately $45,900 \mathrm{mi}^{2}$ in Colorado, New Mexico, and Texas, encompassing the surface-water drainage for the Rio Grande upstream from the USGS water-quality monitoring station Rio Grande at El Paso, Texas; the closed surface-water basins between the Rio Grande and the Continental Divide; and the closed-basin part of the San Luis Basin (fig. 1). The study unit covers parts of three physiographic provinces (Fenneman, 1931) and contains four ecological regions (Omernick, 1987). Vegetation zones vary from the alpine tundra 


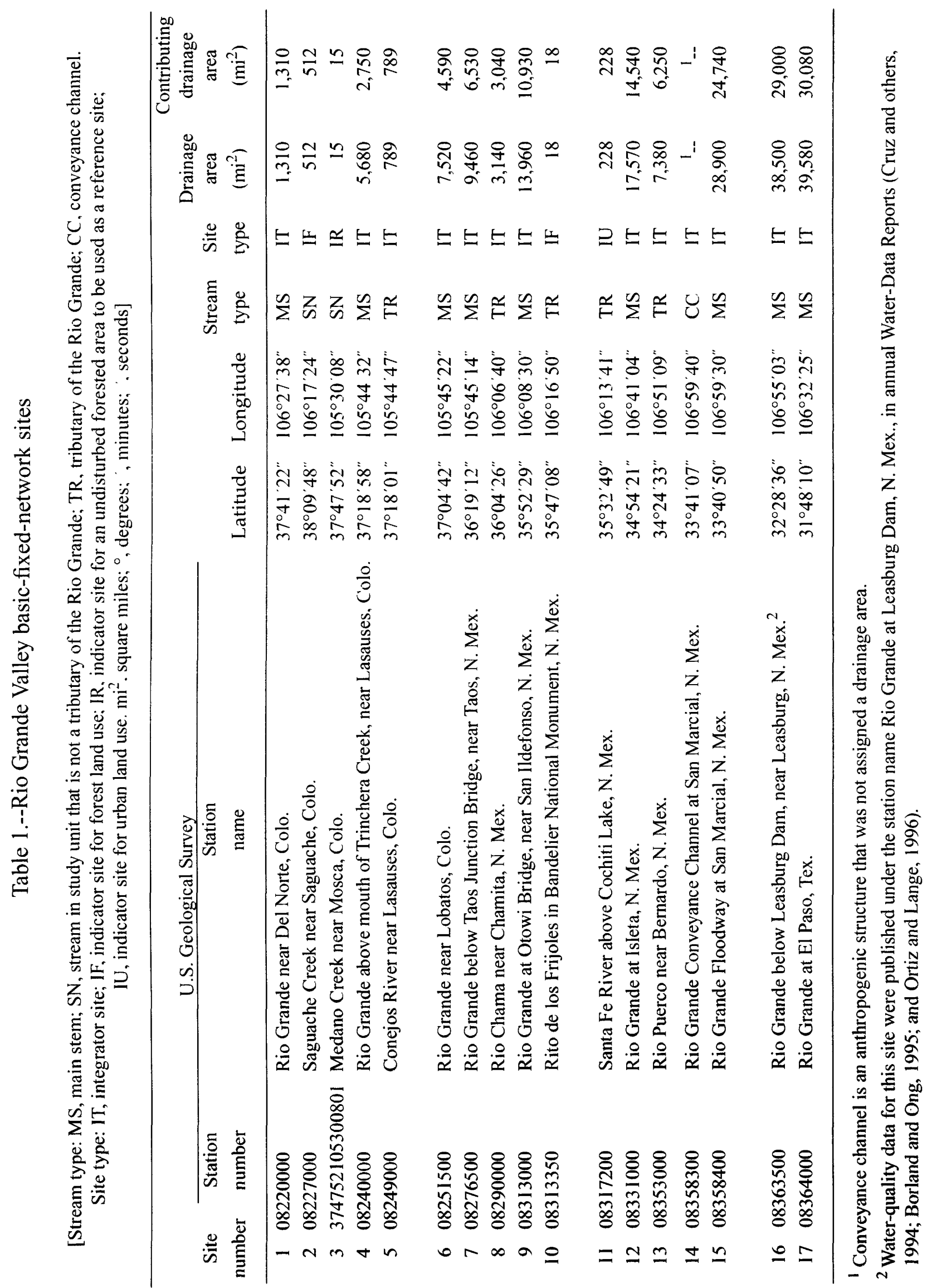


Table 2.--Streamflow, physical properties, and water-quality analytes sampled monthly

[Property or analyte: dissolved, analytes in a representative water sample passed through a 0.45 -micron filter membrane for inorganic analysis or a 0.7-micron glass-fiber filter for organic analysis (Timme, 1995); total, constituents in an unfiltered, representative water-suspended-sediment sample (Timme, 1995). Parameter code, standard five-digit code used by the U.S. Geological Survey Water-Data Storage and Retrieval System (WATSTORE)

(U.S.Geological Survey, 1997) and the U.S. Environmental Protection Agency data system (STORET) (U.S.

Environmental Protection Agency, 1997) that uniquely identifies a specific analyte. Unit: $\mathrm{ft}^{3} / \mathrm{s}$, cubic feet per second; $\mu \mathrm{S} / \mathrm{cm}$, microsiemens per centimeter at 25 degrees Celsius; $\mathrm{mm}$ of $\mathrm{Hg}$, millimeters of mercury; $\mathrm{mg} / \mathrm{L}$, milligrams per liter; $\mu \mathrm{g} / \mathrm{L}$, micrograms per liter. Analytical method: mc. measured or calculated from rating curve; $\mathrm{m}$, measured with appropriate instrument; IT, incremental titration; GR, gravimetric analysis; ICP, inductively coupled plasma; AA, atomic absorption; IC, ion-exchange chromatography; ISE, ion selective electrode; CDZ, colorimetric, diazotization;

$\mathrm{CCDZ}$, colorimetric, cadmium reduction diazotization; $\mathrm{CSH}$, colorimetric, salicylate-hypochlorate; PPMB, colorimetric, phosphomolybdate; VAP, evaporation]

\begin{tabular}{|c|c|c|c|c|}
\hline Property or analyte & $\begin{array}{l}\text { Parameter } \\
\text { code }^{1}\end{array}$ & $\begin{array}{l}\text { Minimum } \\
\text { reporting } \\
\text { level }\end{array}$ & Unit & $\begin{array}{l}\text { Analytical } \\
\text { method }^{2}\end{array}$ \\
\hline \multicolumn{5}{|c|}{ Streamflow, selected physical properties, and selected constituent concentrations (field properties) } \\
\hline Streamflow, instantaneous & 00061 & 0.01 & $\mathrm{ft}^{3} / \mathrm{s}$ & $\mathrm{mc}$ \\
\hline Specific conductance & 00095 & 1 & $\mu \mathrm{S} / \mathrm{cm}$ & $\mathrm{m}$ \\
\hline $\mathrm{pH}$ (hydrogen ion activity) & 00400 & 3 & $\mathrm{pH}$ units & $\mathrm{m}$ \\
\hline Temperature, air & 00020 & -5.0 & degrees Celsius & $\mathrm{m}$ \\
\hline Temperature, water & 00010 & -5.0 & degrees Celsius & $\mathrm{m}$ \\
\hline Barometric pressure & 00025 & 1 & $\mathrm{~mm}$ of $\mathrm{Hg}$ & $\mathrm{m}$ \\
\hline Oxygen, dissolved & 00300 & .05 & $\mathrm{mg} / \mathrm{L}$ & $\mathrm{m}$ \\
\hline Alkalinity, field, dissolved & 39086 & 0 & $\mathrm{mg} / \mathrm{L}$ as $\mathrm{CaCO}_{3}$ & IT \\
\hline \multicolumn{5}{|c|}{ Dissolved solids and major ions } \\
\hline Solids, residue at 180 degrees Celsius (dissolved solids) & $70300 \mathrm{~A}$ & 1 & $\mathrm{mg} / \mathrm{L}$ & GR \\
\hline Calcium & 00915D & .02 & $\mathrm{mg} / \mathrm{L}$ as $\mathrm{Ca}$ & ICP \\
\hline Magnesium & $00925 \mathrm{C}$ & .01 & $\mathrm{mg} / \mathrm{L}$ as $\mathrm{Mg}$ & ICP \\
\hline Sodium & 00930C & .2 & $\mathrm{mg} / \mathrm{L}$ as $\mathrm{Na}$ & ICP \\
\hline Potassium & 00935B & .1 & $\mathrm{mg} / \mathrm{L}$ as $\mathrm{K}$ & $\mathrm{AA}$ \\
\hline Bicarbonate, field, dissolved & 00453 & 0 & $\mathrm{mg} / \mathrm{L}$ as $\mathrm{CaCO}_{3}$ & IT \\
\hline Carbonate, field, dissolved & 00452 & 0 & $\mathrm{mg} / \mathrm{L}$ as $\mathrm{CaCO}_{3}$ & IT \\
\hline Sulfate & $00945 \mathrm{G}$ & .1 & $\mathrm{mg} / \mathrm{L}$ as $\mathrm{SO}_{4}$ & IC \\
\hline Chloride & 00940J & .1 & $\mathrm{mg} / \mathrm{L}$ as $\mathrm{Cl}$ & IC \\
\hline Fluoride & 00950B & .1 & $\mathrm{mg} / \mathrm{L}$ as $\mathrm{F}$ & ISE \\
\hline Silica & $00955 \mathrm{D}$ & .01 & $\mathrm{mg} / \mathrm{L}$ as $\mathrm{SiO}_{2}$ & ICP \\
\hline \multicolumn{5}{|c|}{ Nutrients } \\
\hline Nitrogen, nitrite, dissolved & $00613 \mathrm{~F}$ & 0.01 & $\mathrm{mg} / \mathrm{L}$ as $\mathrm{N}$ & $\mathrm{CDZ}$ \\
\hline Nitrogen, nitrite + nitrate, dissolved & $00631 \mathrm{E}$ & .05 & $\mathrm{mg} / \mathrm{L}$ as $\mathrm{N}$ & $\mathrm{CCDZ}$ \\
\hline Nitrogen, ammonia, dissolved & $00608 \mathrm{~F}$ & .015 & $\mathrm{mg} / \mathrm{L}$ as $\mathrm{N}$ & $\mathrm{CSH}$ \\
\hline Nitrogen, ammonia + organic, dissolved & 00623D & .2 & $\mathrm{mg} / \mathrm{L}$ as $\mathrm{N}$ & $\mathrm{CSH}$ \\
\hline Nitrogen, ammonia + organic, total & $00625 \mathrm{D}$ & .2 & $\mathrm{mg} / \mathrm{L}$ as $\mathrm{N}$ & $\mathrm{CSH}$ \\
\hline Phosphorus, total & $00665 \mathrm{D}$ & .01 & $\mathrm{mg} / \mathrm{L}$ as $\mathrm{P}$ & PPMB \\
\hline Phosphorus, dissolved & $00666 \mathrm{D}$ & .01 & $\mathrm{mg} / \mathrm{L}$ as $\mathrm{P}$ & PPMB \\
\hline Phosphorus, orthophosphate, dissolved & $00671 \mathrm{H}$ & .01 & $\mathrm{mg} / \mathrm{L}$ as $\mathrm{P}$ & PPMB \\
\hline \multicolumn{5}{|c|}{ Selected trace elements } \\
\hline Iron, dissolved & 01046D & 3 & $\mu \mathrm{g} / \mathrm{L}$ as $\mathrm{Fe}$ & ICP \\
\hline Manganese, dissolved & $01056 \mathrm{C}$ & 1 & $\mu \mathrm{g} / \mathrm{L}$ as $\mathrm{Mn}$ & $\mathrm{ICP}$ \\
\hline \multicolumn{5}{|c|}{ Suspended sediment } \\
\hline Sediment, suspended & 80154 & 1 & $\mathrm{mg} / \mathrm{L}$ & VAP \\
\hline
\end{tabular}

${ }^{1}$ Letter code that follows some parameter codes is used by WATSTORE to identify analytical method.

2 Guy (1969); Fishman and Friedman (1989).

${ }^{3}$ Range of reported $\mathrm{pH}$ values can be from 0 to $14 \mathrm{pH}$ units. 


\section{Table 3.--Supplemental trace-element and organic-carbon analytes}

[Analyte: whole water recoverable, because of incomplete digestion determination represents a value less than the total amount (less than 95 percent) of the analyte present in the dissolved and suspended phases (Timme, 1995); dissolved, analytes in a representative water sample passed through a 0.45 -micron filter membrane for inorganic analysis or a 0.7 -micron glass-fiber filter for organic analysis (Timme, 1995). Parameter code, standard five-digit code used by the U.S. Geological Survey Water-Data Storage and Retrieval System (WATSTORE) (U.S. GeologicaI

Survey, 1997) and the U.S. Environmental Protection Agency data system (STORET) (U.S. Environmental

Protection Agency, 1997) that uniquely identifies a specific analyte. Unit: $\mu \mathrm{g} / \mathrm{L}$, micrograms per Iiter; $\mathrm{mg} / \mathrm{L}$, milligrams per liter. Analytical method: DCP, direct-current plasma: ICP/MS, inductively coupled plasma / mass spectrometry; AA, atomic absorption; ICP, inductively coupled plasma; GFAA, graphite furnace atomic absorption;

BAASF, barbituric acid, automated-segmented flow, colorimetric; CVAA, cold vapor atomic absorption;

WOX, wet oxidation]

\begin{tabular}{|c|c|c|c|c|}
\hline Analyte & $\begin{array}{l}\text { Parameter } \\
\text { code }^{l}\end{array}$ & $\begin{array}{c}\text { Minimum } \\
\text { reporting } \\
\text { level }\end{array}$ & Unit & $\begin{array}{c}\text { Analytical } \\
\text { method }^{2}\end{array}$ \\
\hline Aluminum, whole water recoverable & $01105 \mathrm{C}$ & 10 & $\mu \mathrm{g} / \mathrm{L}$ as $\mathrm{Al}$ & DCP \\
\hline \multirow[t]{2}{*}{ Aluminum, dissolved } & $01106 \mathrm{G}$ & 1 & $\mu \mathrm{g} / \mathrm{L}$ as $\mathrm{A} 1$ & $\mathrm{ICP} / \mathrm{MS}$ \\
\hline & $01106 \mathrm{E}$ & 10 & $\mu \mathrm{g} / \mathrm{L}$ as $\mathrm{Al}$ & DCP \\
\hline Antimony, whole water recoverable & $01097 \mathrm{~A}$ & 1 & $\mu \mathrm{g} / \mathrm{L}$ as $\mathrm{Sb}$ & AA \\
\hline Antimony, dissolved & $01095 \mathrm{G}$ & 1 & $\mu \mathrm{g} / \mathrm{L}$ as $\mathrm{Sb}$ & ICP/MS \\
\hline Arsenic, whole water recoverable & 01002B & 1 & $\mu \mathrm{g} / \mathrm{L}$ as $\mathrm{As}$ & $\mathrm{AA}$ \\
\hline Arsenic, dissolved & 01000B & 1 & $\mu \mathrm{g} / \mathrm{L}$ as $\mathrm{As}$ & ICP/MS \\
\hline Barium, whole water recoverable & $01007 \mathrm{~A}$ & 100 & $\mu \mathrm{g} / \mathrm{L}$ as $\mathrm{Ba}$ & $\mathrm{AA}$ \\
\hline \multirow[t]{2}{*}{ Barium, dissolved } & $01005 \mathrm{G}$ & 1 & $\mu \mathrm{g} / \mathrm{L}$ as $\mathrm{Ba}$ & ICP/MS \\
\hline & $01005 \mathrm{C}$ & 2 & $\mu \mathrm{g} / \mathrm{L}$ as $\mathrm{Ba}$ & ICP \\
\hline Beryllium, whole water recoverable & $01012 \mathrm{~A}$ & 10 & $\mu \mathrm{g} / \mathrm{L}$ as $\mathrm{Be}$ & AA \\
\hline Beryllium, dissolved & $01010 \mathrm{G}$ & 1 & $\mu \mathrm{g} / \mathrm{L}$ as $\mathrm{Be}$ & $\mathrm{ICP} / \mathrm{MS}$ \\
\hline Boron, whole water recoverable & 01022B & 10 & $\mu \mathrm{g} / \mathrm{L}$ as $\mathrm{B}$ & DCP \\
\hline Boron, dissolved & $01020 \mathrm{G}$ & 10 & $\mu \mathrm{g} / \mathrm{L}$ as $B$ & DCP \\
\hline Cadmium, whole water recoverable & $01027 \mathrm{~F}$ & 1 & $\mu \mathrm{g} / \mathrm{L}$ as $\mathrm{Cd}$ & GFAA \\
\hline \multirow[t]{2}{*}{ Cadmium, dissolved } & $01025 \mathrm{~F}$ & 1 & $\mu \mathrm{g} / \mathrm{L}$ as $\mathrm{Cd}$ & GFAA \\
\hline & $01025 \mathrm{G}$ & 1 & $\mu \mathrm{g} / \mathrm{L}$ as $\mathrm{Cd}$ & ICP/MS \\
\hline Chromium, whole water recoverable & $01034 \mathrm{E}$ & 1 & $\mu \mathrm{g} / \mathrm{L}$ as $\mathrm{Cr}$ & GFAA \\
\hline \multirow[t]{2}{*}{ Chromium, dissolved } & 01030I & 1 & $\mu \mathrm{g} / \mathrm{L}$ as $\mathrm{Cr}$ & GFAA \\
\hline & 01030G & 1 & $\mu \mathrm{g} / \mathrm{L}$ as $\mathrm{Cr}$ & $\mathrm{ICP} / \mathrm{MS}$ \\
\hline Cobalt, whole water recoverable & $01037 \mathrm{~F}$ & 1 & $\mu \mathrm{g} / \mathrm{L}$ as $\mathrm{Co}$ & GFAA \\
\hline \multirow[t]{2}{*}{ Cobalt, dissolved } & $01035 \mathrm{G}$ & 1 & $\mu \mathrm{g} / \mathrm{L}$ as $\mathrm{Co}$ & $\mathrm{ICP} / \mathrm{MS}$ \\
\hline & $01035 \mathrm{C}$ & 3 & $\mu \mathrm{g} / \mathrm{L}$ as $\mathrm{Co}$ & $\mathrm{ICP}$ \\
\hline Copper, whole water recoverable & $01042 \mathrm{~F}$ & 1 & $\mu \mathrm{g} / \mathrm{L}$ as $\mathrm{Cu}$ & GFAA \\
\hline \multirow[t]{2}{*}{ Copper, dissolved } & $01040 \mathrm{~F}$ & 1 & $\mu \mathrm{g} / \mathrm{L}$ as $\mathrm{Cu}$ & GFAA \\
\hline & 01040G & 1 & $\mu \mathrm{g} / \mathrm{L}$ as $\mathrm{Cu}$ & $\mathrm{ICP} / \mathrm{MS}$ \\
\hline Cyanide, whole water recoverable & 00720 & 10 & $\mu \mathrm{g} / \mathrm{L}$ as $\mathrm{Cn}$ & BAASF \\
\hline Cyanide, dissolved & 00723 & 10 & $\mu \mathrm{g} / \mathrm{L}$ as $\mathrm{Cn}$ & BAASF \\
\hline Iron, whole water recoverable & $01045 B$ & 10 & $\mu \mathrm{g} / \mathrm{L}$ as $\mathrm{Fe}$ & AA \\
\hline Lead, whole water recoverable & $01051 \mathrm{~F}$ & 1 & $\mu \mathrm{g} / \mathrm{L}$ as $\mathrm{Pb}$ & GFAA \\
\hline
\end{tabular}




\begin{tabular}{|c|c|c|c|c|}
\hline Analyte & $\begin{array}{c}\text { Parameter } \\
\text { code }^{1}\end{array}$ & $\begin{array}{c}\text { Minimum } \\
\text { reporting } \\
\text { level }\end{array}$ & Unit & $\begin{array}{c}\text { Analytical } \\
\text { method }^{2}\end{array}$ \\
\hline Lead, dissolved & $\begin{array}{l}01049 \mathrm{~F} \\
01049 \mathrm{G}\end{array}$ & $\begin{array}{l}1 \\
1\end{array}$ & $\begin{array}{l}\mu \mathrm{g} / \mathrm{L} \text { as } \mathrm{Pb} \\
\mu \mathrm{g} / \mathrm{L} \text { as } \mathrm{Pb}\end{array}$ & $\begin{array}{l}\text { GFAA } \\
1 \mathrm{CP} / \mathrm{MS}\end{array}$ \\
\hline Lithium, whole water recoverable & $01132 \mathrm{~A}$ & 10 & $\mu \mathrm{g} / \mathrm{L}$ as $\mathrm{Li}$ & $\mathrm{AA}$ \\
\hline Lithium, dissolved & $01130 \mathrm{~B}$ & 4 & $\mu \mathrm{g} / \mathrm{L}$ as $\mathrm{Li}$ & ICP \\
\hline Manganese, whole water recoverable & $01055 \mathrm{~A}$ & 10 & $\mu \mathrm{g} / \mathrm{L}$ as $\mathrm{Mn}$ & $\mathrm{AA}$ \\
\hline Mercury, whole water recoverable & $71900 \mathrm{~B}$ & .1 & $\mu \mathrm{g} / \mathrm{L}$ as $\mathrm{Hg}$ & CVAA \\
\hline Mercury, dissolved & $71890 \mathrm{~B}$ & .1 & $\mu \mathrm{g} / \mathrm{L}$ as $\mathrm{Hg}$ & CVAA \\
\hline Molybdenum, whole water recoverable & $01062 \mathrm{~A}$ & 1 & $\mu \mathrm{g} / \mathrm{L}$ as $\mathrm{Mo}$ & GFAA \\
\hline Molybdenum, dissolved & $\begin{array}{l}01060 \mathrm{G} \\
01060 \mathrm{~A}\end{array}$ & $\begin{array}{r}1 \\
10\end{array}$ & $\begin{array}{l}\mu \mathrm{g} / \mathrm{L} \text { as } \mathrm{Mo} \\
\mu \mathrm{g} / \mathrm{L} \text { as } \mathrm{Mo}\end{array}$ & $\begin{array}{l}\text { 1CP/MS } \\
\text { ICP }\end{array}$ \\
\hline Nickel, whole water recoverable & $01067 \mathrm{~F}$ & 1 & $\mu \mathrm{g} / \mathrm{L}$ as $\mathrm{Ni}$ & GFAA \\
\hline Nickel, dissolved & $\begin{array}{l}01065 \mathrm{~F} \\
01065 \mathrm{G}\end{array}$ & $\begin{array}{l}1 \\
1\end{array}$ & $\begin{array}{l}\mu \mathrm{g} / \mathrm{L} \text { as } \mathrm{Ni} \\
\mu \mathrm{g} / \mathrm{L} \text { as } \mathrm{Ni}\end{array}$ & $\begin{array}{l}\text { GFAA } \\
\text { ICP/MS }\end{array}$ \\
\hline Selenium, whole water recoverable & $01147 \mathrm{~A}$ & 1 & $\mu \mathrm{g} / \mathrm{L}$ as $\mathrm{Se}$ & AA, hydride \\
\hline Selenium, dissolved & $01145 \mathrm{~A}$ & 1 & $\mu \mathrm{g} / \mathrm{L}$ as $\mathrm{Se}$ & AA, hydride \\
\hline Silver, whole water recoverable & $01077 \mathrm{~F}$ & 1 & $\mu \mathrm{g} / \mathrm{L}$ as $\mathrm{Ag}$ & GFAA \\
\hline Silver, dissolved & $\begin{array}{l}01075 \mathrm{~F} \\
01075 \mathrm{G}\end{array}$ & $\begin{array}{l}1 \\
1\end{array}$ & $\begin{array}{l}\mu \mathrm{g} / \mathrm{L} \text { as } \mathrm{Ag} \\
\mu \mathrm{g} / \mathrm{L} \text { as } \mathrm{Ag}\end{array}$ & $\begin{array}{l}\text { GFAA } \\
\text { ICP/MS }\end{array}$ \\
\hline Strontium, whole water recoverable & $01082 \mathrm{~A}$ & 10 & $\mu \mathrm{g} / \mathrm{L}$ as $\mathrm{Sr}$ & $\mathrm{AA}$ \\
\hline Strontium, dissolved & 01080B & .1 & $\mu \mathrm{g} / \mathrm{L}$ as $\mathrm{Sr}$ & ICP \\
\hline Uranium, dissolved & $22703 \mathrm{G}$ & 1 & $\mu \mathrm{g} / \mathrm{L}$ as $\mathrm{U}$ & ICP/MS \\
\hline Vanadium, dissolved & $01085 B$ & 6 & $\mu \mathrm{g} / \mathrm{L}$ as $\mathrm{V}$ & ICP \\
\hline Zinc, whole water recoverable & 01092A & 10 & $\mu \mathrm{g} / \mathrm{L}$ as $\mathrm{Zn}$ & AA \\
\hline Zinc, dissolved & $\begin{array}{l}01090 \mathrm{G} \\
01090 \mathrm{~A}\end{array}$ & $\begin{array}{r}1 \\
10\end{array}$ & $\begin{array}{l}\mu \mathrm{g} / \mathrm{L} \text { as } \mathrm{Zn} \\
\mu \mathrm{g} / \mathrm{L} \text { as } \mathrm{Zn}\end{array}$ & $\begin{array}{l}\text { ICP/MS } \\
\text { AA }\end{array}$ \\
\hline Carbon, organic, total & $00680 \mathrm{~A}$ & .1 & $\mathrm{mg} / \mathrm{L}$ as $\mathrm{C}$ & WOX \\
\hline Carbon, organic, dissolved & $00681 \mathrm{~A}$ & .1 & $\mathrm{mg} / \mathrm{L}$ as $\mathrm{C}$ & WOX \\
\hline Carbon, organic, suspended & $00689 \mathrm{~A}$ & .1 & $\mathrm{mg} / \mathrm{L}$ as $\mathrm{C}$ & WOX \\
\hline
\end{tabular}

${ }^{1}$ Letter code that follows some parameter codes is used by WATSTORE to identify analytical method.

${ }^{2}$ Wershaw and others (1987); Fishman and Friedman (1989); Faires (1993). 
Table 4.--Supplemental pesticide and metabolite analytes

[Parameter code, standard five-digit code used by the U.S. Geological Survey Water-Data Storage and Retrieval System (WATSTORE) (U.S. Geological Survey, 1997) and the U.S. Environmental Protection Agency data system (STORET) (U.S. Environmental Protection Agency, 1997) that uniquely identifies a specific analyte. Pesticides listed in the left columns extracted by $\mathrm{C}-18$ solid-phase extraction cartridge and analyzed by gas chromatography/mass spectrometric detector (Zaugg and others, 1995). Pesticides listed

in the right columns extracted by Carbopak-B solid-phase extraction cartridge and analyzed by highperformance liquid chromatography (Werner and others, 1996). Pesticide method detection limits are in micrograms per liter]

\begin{tabular}{|c|c|c|c|c|c|}
\hline Analyte & $\begin{array}{l}\text { Parameter } \\
\text { code }^{1}\end{array}$ & $\begin{array}{c}\text { Method } \\
\text { detection } \\
\text { limit }\end{array}$ & Analyte & $\begin{array}{l}\text { Parameter } \\
\text { code }^{1}\end{array}$ & $\begin{array}{c}\text { Method } \\
\text { detection } \\
\text { limit }\end{array}$ \\
\hline Acetochlor & $49260 \mathrm{~A}$ & 0.002 & Acifluorfen & $49315 \mathrm{~A}$ & 0.035 \\
\hline Alachlor & 46342D & .002 & Aldicarb & $49312 \mathrm{~A}$ & .016 \\
\hline Atrazine & 39632D & .001 & Aldicarb sulfone & $49313 \mathrm{~A}$ & .016 \\
\hline Benfluralin & $82673 \mathrm{D}$ & .002 & Aldicarb sulfoxide & 49314A & .021 \\
\hline Alpha BHC & $34253 \mathrm{D}$ & .002 & Bentazon & $38711 \mathrm{~A}$ & .014 \\
\hline Butylate & $04028 \mathrm{D}$ & .002 & Bromacil & 04029A & .035 \\
\hline Carbaryl & $82680 \mathrm{D}$ & .003 & Bromoxynil & $49311 \mathrm{~A}$ & .035 \\
\hline Carbofuran & $82674 \mathrm{D}$ & .003 & Carbaryl & $49310 \mathrm{~A}$ & .008 \\
\hline Chlorpyrifos & 38933D & .004 & Carbofuran & $49309 \mathrm{~A}$ & .028 \\
\hline Cyanazine & $04041 \mathrm{D}$ & .004 & 3-OH-carbofuran & $49308 \mathrm{~A}$ & .014 \\
\hline DCPA & $82682 \mathrm{D}$ & .002 & Chloramben & $49307 \mathrm{~A}$ & .011 \\
\hline p.p'-DDE & 34653D & .006 & Chlorothalonil & $49306 \mathrm{~A}$ & .035 \\
\hline Deethyl atrazine & 04040D & .002 & Clopyralid & $49305 \mathrm{~A}$ & .050 \\
\hline Diazinon & 39572D & .002 & $2,4-\mathrm{D}$ & $39372 B$ & .035 \\
\hline Dieldrin & $39381 \mathrm{D}$ & .001 & 2,4-DB & $38746 \mathrm{~A}$ & .035 \\
\hline 2,6 Diethylaniline & $82660 \mathrm{D}$ & .003 & Dacthal, MA & $49304 \mathrm{~A}$ & .017 \\
\hline Disulfoton & $82677 \mathrm{D}$ & .017 & Dicamba & $38442 \mathrm{~A}$ & .035 \\
\hline EPTC & $82668 \mathrm{D}$ & .002 & Dichlobenil & $49303 \mathrm{~A}$ & .020 \\
\hline Ethalfluralin & $82663 \mathrm{D}$ & .004 & Dichlorprop & 49302A & .032 \\
\hline Ethoprop & $82672 \mathrm{D}$ & .003 & Dinoseb & $49301 \mathrm{~A}$ & .035 \\
\hline Fonofos & 04095D & .003 & Diuron & $49300 \mathrm{~A}$ & .020 \\
\hline Lindane $(\gamma-\mathrm{HCH})$ & $3934 ! \mathrm{D}$ & .004 & DNOC & $49299 A$ & .035 \\
\hline Linuron & $82666 \mathrm{D}$ & .002 & Esfenvalerate & 49298A & .019 \\
\hline Malathion & 39532D & .005 & Fenuron & 49297A & .013 \\
\hline Methyl azinphos & $82686 \mathrm{D}$ & .001 & Fluometuron & $38811 \mathrm{~A}$ & .035 \\
\hline Methyl parathion & $82667 \mathrm{D}$ & .006 & Linuron & $38478 \mathrm{~A}$ & .018 \\
\hline Metolachlor & 39415D & .002 & MCPA & $38482 \mathrm{~A}$ & .050 \\
\hline Metribuzin & $82630 \mathrm{D}$ & .004 & МСРВ & $38487 \mathrm{~A}$ & .035 \\
\hline Molinate & $82671 \mathrm{D}$ & .004 & Methiocarb & $38501 \mathrm{~A}$ & .026 \\
\hline Napropamide & 82684D & .003 & Methomyl & 49296A & .017 \\
\hline
\end{tabular}


Table 4.--Supplemental pesticide and metabolite analytes--Concluded

\begin{tabular}{|c|c|c|c|c|c|}
\hline Analyte & $\begin{array}{l}\text { Parameter } \\
\text { code }^{1}\end{array}$ & $\begin{array}{c}\text { Method } \\
\text { detection } \\
\text { limit }\end{array}$ & Analyte & $\begin{array}{l}\text { Parameter } \\
\text { code }^{1}\end{array}$ & $\begin{array}{c}\text { Method } \\
\text { detection } \\
\text { limit }\end{array}$ \\
\hline Parathion & 39542D & 0.004 & 1-Naphthol & $49295 \mathrm{~A}$ & 0.007 \\
\hline Pebulate & 82669D & .004 & Neburon & $49294 \mathrm{~A}$ & .015 \\
\hline Pendimethalin & $82683 \mathrm{D}$ & .004 & Norflurazon & $49293 \mathrm{~A}$ & .024 \\
\hline Permethrin & $82687 \mathrm{D}$ & .005 & Oryzalin & $49292 \mathrm{~A}$ & .019 \\
\hline Phorate & $82664 \mathrm{D}$ & .002 & Oxamyl & $38866 \mathrm{~A}$ & .018 \\
\hline Prometon & 04037D & .018 & Picloram & $49291 \mathrm{~A}$ & .050 \\
\hline Pronamide & $82676 \mathrm{D}$ & .003 & Propham & $49236 \mathrm{~A}$ & .035 \\
\hline Propachlor & 04024D & .007 & Propoxur & $38538 \mathrm{~A}$ & .035 \\
\hline Propanil & 82679D & .013 & Silvex & 39762B & .021 \\
\hline Propargite & $82685 \mathrm{D}$ & .004 & $2,4,5-\mathrm{T}$ & 39742B & .035 \\
\hline Simazine & 04035D & .005 & Triclopyr & $49235 \mathrm{~A}$ & .050 \\
\hline Tebuthiuron & $82670 \mathrm{D}$ & .010 & & & \\
\hline Terbacil & $82665 \mathrm{D}$ & .007 & & & \\
\hline Terbufos & $82675 \mathrm{D}$ & .013 & & & \\
\hline Thiobencarb & $82681 \mathrm{D}$ & .002 & & & \\
\hline Triallate & $82678 \mathrm{D}$ & .001 & & & \\
\hline Trifuralin & $82661 \mathrm{D}$ & .002 & & & \\
\hline
\end{tabular}

${ }^{1}$ Letter code that follows some parameter codes is used by WATSTORE to identify analytical method. 
EXPLANATION

SOUTHERN BOUNDARY OF SAN LUIS CLOSED BASIN

- 1 BASIC-FIXED SITE AND SITE NUMBER (TABLE 1)

NM NATIONAL MONUMENT

NWR NATIONAL WILDLIFE REFUGE
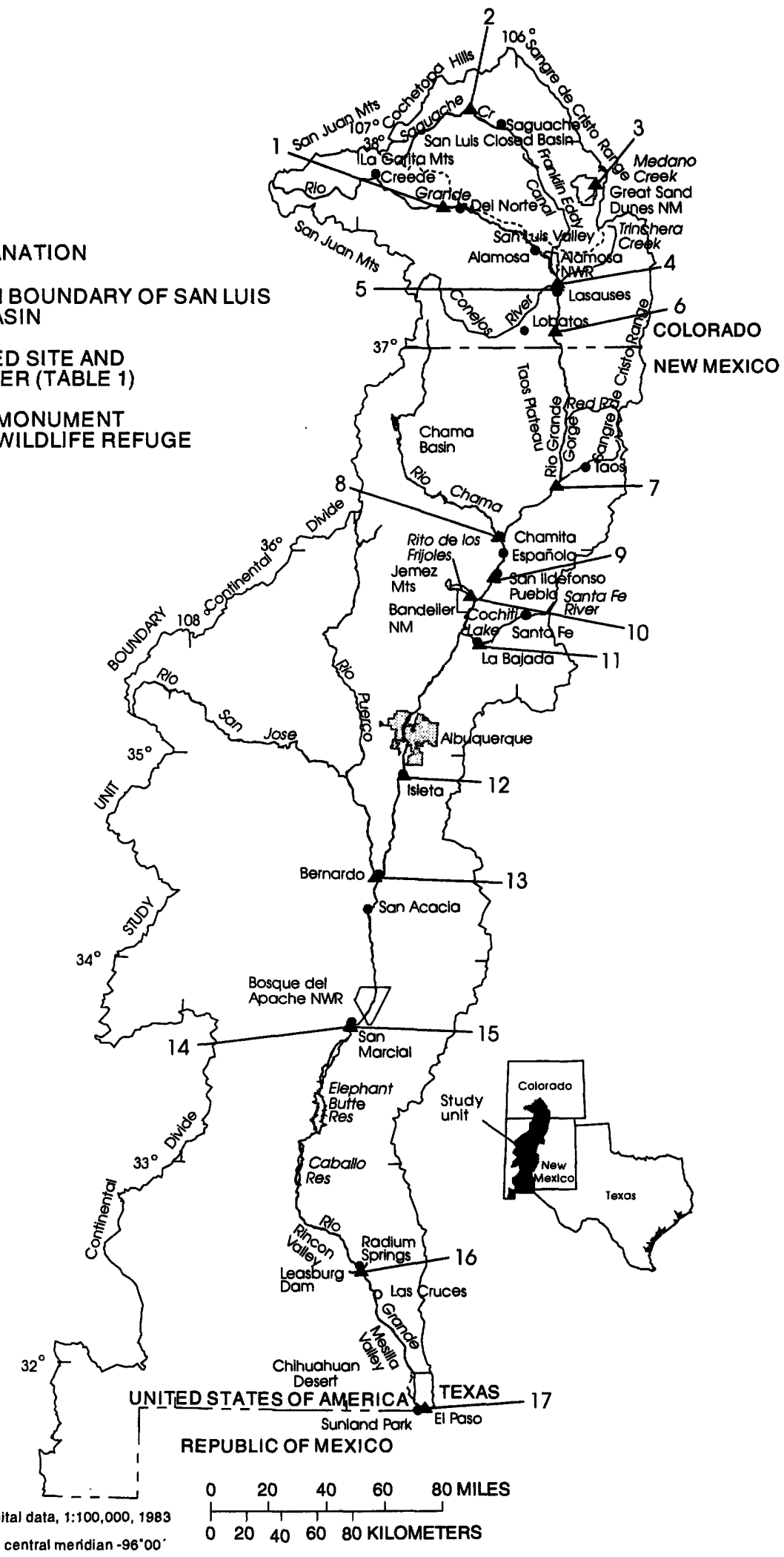

Base trom U.S. Geological Survey digital data, 1:100,000, 1983 Albers Equal-Area Conic projection
$\begin{array}{lcccc}1 & 1 & 1 & 1 \\ 0 & 20 & 40 & 60 & 80 \text { KILOMETERS }\end{array}$

Figure 1.--Rio Grande Valley study unit. 
regions of the San Juan Mountains in Colorado and Sangre de Cristo Range in Colorado and New Mexico to the Chihuahuan Desert in southern New Mexico and Texas (fig. 1). Land use in the study unit is mainly rangeland ( 71 percent), forest ( 22 percent), and agriculture (6 percent) (Anderson and others, 1976; U.S. Geological Survey, 1986). A detailed description of the environmental setting of the Rio Grande Valley study unit is presented in Ellis and others (1993).

\section{Data Collection and Laboratory Analysis Methods}

Water-quality samples were collected and processed at basic-fixed sites following protocols described in Shelton (1994). Depth- and widthintegrated samples were composited, then split into separate samples for most analytical determinations. Water temperature and dissolved-oxygen (DO) concentrations were measured at one location in the cross section, and organic-carbon samples were dip samples collected from one vertical in the cross section. Streamflow was measured following procedures in Buchanan and Somers (1969) or was calculated from gage height-discharge rating curves (Kilpatrick and Schneider, 1983; Kennedy, 1984).

Most of the samples were analyzed at the USGS National Water Quality Laboratory (NWQL) in Arvada, Colorado. The samples to be analyzed for nutrients, organic carbon. and pesticides were shipped as soon as possible by overnight express. Nutrient samples initially were shipped chilled with mercuric chloride as a preservative; however, after qualitycontrol tests by the NWQL found no statistical difference in nutrient concentrations between samples chilled and preserved with mercuric chloride and samples chilled with no preservative (D.A. Rickert, U.S. Geological Survey, written commun., 1994), the nutrient samples were shipped chilled without preservatives. Samples to be analyzed for DS, major constituents, and trace elements were shipped either with the above samples or at a later date. The methods of analysis for the various different analytes are listed in tables 2, 3, and 4. Descriptions of the analytical methods used for DS, major constituents, nutrients, and dissolved iron and manganese can be found in Fishman and Friedman (1989); for the additional trace elements in Faires (1993); for organic carbon in Wershaw and others (1987); and for pesticides in Zaugg and others (1995), Lindley and others (1996), and Werner and others (1996). Alkalinity, carbonate, and bicarbonate concentrations were analyzed at the sampling site by incremental titration. Suspended-sediment concentrations were measured at the USGS New Mexico District sediment laboratory using methods described in Guy (1969).

\section{Data Summary and Analysis Methods}

In this report, major-constituent, nutrient, and trace-element data are reported as censored or uncensored. Censored data are data reported as less than a value, generally the minimum reporting level (MRL). The MRL is defined by the NWQL as the smallest concentration of an analyte that may be reliably reported using a given analytical method (Timme, 1995). Uncensored data are data for which an unqualified numerical value is given.

Mean and standard deviation for data sets with censored data were calculated in one of three ways. For sets that had less than 20 percent censored data, the censored data were assigned a value one-half the MRL, and the mean and standard deviation were calculated in the usual manner. For sets that had between 20 and 80 percent inclusive censored data, the mean and standard deviation were calculated by $\log$-probability regression (Gilliom and Helsel, 1986). If, however, the uncensored data did not contain at least three unique values, there was not sufficient variation to perform log-probability regression. For these sets, a range was calculated for the mean by assigning the censored data a value of zero to calculate the lower end of the range and then assigning the censored data a value equal to the MRL to calculate the upper end of the range. The standard deviation was not reported for these data sets. For sets that had more than 80 percent censored data, a range for the mean was calculated by the above procedure and the standard deviation was not reported.

The mean for $\mathrm{pH}$ was calculated by transforming the $\mathrm{pH}$ data to hydrogen ion activity values, determining the mean of these values, and then transforming this mean back to $\mathrm{pH}$ units. All other statistical values for $\mathrm{pH}$ were calculated directly from $\mathrm{pH}$ units.

Because un-ionized ammonia is highly toxic to aquatic life, un-ionized ammonia concentrations were calculated and included in tables with the dissolvedammonia data. Un-ionized ammonia concentrations for data sets that had censored dissolved-ammonia 
concentrations were calculated by assigning the ammonia MRL value to the censored data. This process is a conservative measure that creates a high bias for these calculated values. None of the un-ionized ammonia concentrations calculated by using the ammonia MRL value exceeded any water-quality standards or criteria.

Pesticide concentrations in this report are reported as censored, uncensored, or estimated data. Censored pesticide data are data reported as less than the method detection limit (MDL), which is defined by the NWQL as the minimum concentration at which a compound can be identified, measured, and reported with 99-percent confidence that the compound concentration is greater than zero (Timme, 1995). Pesticide data reported as censored can result when the compound is not present or, if present, the compound cannot be conclusively identified and measured. Uncensored pesticide data are data for which an unqualified numerical value is given. Estimated pesticide data are data for which a qualified numerical value is given. Estimated values less than the MDL are data for which the compound can be identified and measured, but with less than 99-percent confidence that the compound is actually present. Estimated values at or above the MDL can result from a poor performance record of the analyte with the analytical method used (Zaugg and others, 1995), matrix interference, or small sample volume (J.W. Pritt, National Water Quality Laboratory, written commun., 1994). Estimated concentrations in this report are identified by an $\mathrm{E}$ before the value.

Relations among field properties and analytes were examined by using Kendall's tau correlation coefficients, a rank-based procedure that measures the strength of the monotonic relation between two variables (Helsel and Hirsch, 1992). This procedure is resistent to outliers, measures linear and nonlinear monotonic correlations, and can be used with censored data. Kendall's tau correlation coefficients were generated for all data collectively and for each site separately. For this report, coefficients greater than or equal to 0.7 or less than or equal to -0.7 show a strong correlation, coefficients between 0.3 and 0.7 or between -0.3 and -0.7 show a moderate correlation, and coefficients between -0.3 and 0.3 inclusive show no correlation. The strong correlations were graphed to confirm that the correlation was a true indication of the relation.
Regression equations for estimating DS, majorconstituent, nutrient, iron, and manganese concentrations were developed by entering the data into a multiple regression statistical package and picking the "best fit" regression equation by Mallow's $\mathrm{Cp}$ (Ott, 1993). The possible independent variables in the equations were limited to instantaneous streamflow, specific conductance, $\mathrm{pH}$, water temperature, $\mathrm{DO}$, and a temporal variable to represent seasonality. For analytes that had between 5 and 20 percent censored data, a Kendall-Theil robust line (Helsel and Hirsch, 1992) was calculated between the analyte and the independent variable with the strongest Kendall's tau correlation. The Kendall-Theil robust line goes through the median of the data. Estimates made from these lines are strongest near the median and become weaker near the extremes (maximum and minimum) of the data. For analytes that had greater than 20 percent censored values, no equation was developed.

The regression equations can be used to estimate the analyte concentrations at each of the sites; however, these regression equations are statistically derived "best fit" and may or may not have any connection with actual physical, chemical, or biological processes. Also, analysis of additional data may result in changes to these equations.

The tables provide the adjusted coefficient of determination $\left(R^{2}\right)(O t t, 1993)$ for each multiple regression. This statistic gives the fraction of the variance in the analyte explained by the equation.

Two-tailed Wilcoxon signed-rank nonparametric statistical tests were used to examine the difference in data among sites. Nonparametric tests use the ranking of the data rather than the data values themselves. Twotailed tests assume that the difference can be greater or less, whereas a one-tailed test assumes a direction. A description of the Wilcoxon signed-rank test can be found in Ott (1993). If the result of the statistical test was equal to or greater than the 95-percent confidence level, then the data sets were accepted as statistically different. If the result was less than the 95-percent confidence level, the difference between the data sets was assumed to be due to chance and not significant.

\section{Acknowledgments}

The author thanks the members of the RIOG Liaison Committee for their assistance in the design of the basic-fixed-site network and the various Federal, State, local, and Indian pueblo government personnel 
who contributed to the success of the data collection effort by assisting with water-quality sampling, measuring streamflow, or supplying ancillary data. The author also thanks Harriet R. Allen, Todd M. Kelly, and Gary K. Speiran for their reviews and comments in the preparation of this report. Steven F. Richey prepared the map and graphical displays used in this report.

The author particularly wishes to acknowledge the USGS Hydrologic Technicians responsible for collecting most of the data used in this report: Lynn $\mathrm{K}$. Miller, Robert M. Moquino, and Bruce A. Hill. Bruce R. Goddard, Lee W. Lewis, and Stephanie L. Marr (Lundstrom) of the USGS also assisted in the data collection effort at various times.

\section{BASIC-FIXED-SITE NETWORK}

The basic-fixed-site network sampling program provides the data needed to assess spatial and temporal water-quality trends. Two site types are in this network: integrator sites and indicator sites. Integrator sites are located downstream from large, complex drainage basins that often contain multiple environmental settings. Indicator sites are located at outlets of drainage basins that have homogeneous land use and physiographic conditions. Gilliom and others (1995) discussed the purpose of the basic-fixed-site network, the logic behind site selection, and the sampling strategy used to choose sampling sites from the NAWQA perspective.

The RIOG basic-fixed-site network consists of 17 sites, of which 13 are integrator sites and 4 are indicator sites. The integrator sites include all nine main-stem sites (sites 1, 4, 6,7,9,12, and 15-17), three tributary sites (sites 5,8, and 13), and the conveyance channel site (site 14) (table 1). Site 14 is classified as an integrator site although it is on an anthropogenic structure and not assigned a drainage basin area. The indicator sites include two tributary sites (sites 10 and 11 ) and two sites on streams in the study unit that are not direct tributaries to the Rio Grande (sites 2 and 3) (table 1). Sites 2 and 3 are on streams that discharge into the San Luis Closed Basin, which is defined by a topographic divide that prevents surface water from naturally draining into the Rio Grande (Ellis and others, 1993). The indicator sites can be further classified as an indicator site for urban land use (site 11 ), indicator sites for forest land (sites 2 and 10), and a reference site for forest land (site 3) (table 1). Reference sites are located downstream from undisturbed drainages that represent the selected physiographic and ecological regions within the study unit and are chosen to represent background conditions (Gilliom and others, 1995).

\section{SUMMARY AND ANALYSIS OF MONTHLY WATER-QUALITY DATA}

This section presents summaries and analyses of the field-property and chemical-analyte data for the monthly samples. The monthly data for all sites are examined collectively in separate sections for field properties, DS and major constituents, nutrients, and dissolved iron and dissolved manganese. The monthly samples for individual sites are then examined separately.

\section{Field Properties}

Field properties are the determinations measured in the field because these measurements that represent ambient field conditions cannot be made elsewhere (table 2). Because of its influence on and relation to water quality, instantaneous streamflow is included in this report although it is not a water-quality property. Instantaneous streamflow was smallest at the indicator sites on the perennial streams draining small basins and largest at integrator sites 9 and 12 on the main stem. Instantaneous streamflow ranged from $0.26 \mathrm{ft}^{3} / \mathrm{s}$ at site 10 to $7,960 \mathrm{ft}^{3} / \mathrm{s}$ at site 9 . At various times during the high-intensity sampling phase, however, there was no streamflow at some basic-fixed sites. The median instantaneous streamflow at each individual site ranged from $1.4 \mathrm{ft}^{3} / \mathrm{s}$ at site 10 to $1,380 \mathrm{ft}^{3} / \mathrm{s}$ at site 9 .

Collectively for the basic-fixed sites, instantaneous streamflow showed no correlation with all other field properties and chemical analytes, mainly due to the different instantaneous streamflows among the various sites. For individual sites, however, instantaneous streamflow was strongly correlated with specific field properties and chemical analytes.

At most sites, instantaneous streamflow fluctuated seasonally, and the largest flows were during snowmelt in the spring. However, summer thunderstorms caused the largest flows at site 13, and releases from Caballo Reservoir for irrigation caused the largest flows at sites 16 and 17 . 
Specific-conductance values also had a wide range at the basic-fixed sites. Specific-conductance values generally were lower at the indicator sites draining small forested basins (sites 2, 3, and 10) and integrator sites 1 and 5. Specific-conductance values generally were greater at integrator sites 13 on an ephemeral tributary, 14 on the conveyance channel, and 16 and 17 on the main stem in the lower part of the study unit. Specific conductance ranged from 42 microsiemens per centimeter at $25^{\circ} \mathrm{C}(\mu \mathrm{S} / \mathrm{cm})$ at sites 1 and 3 to $2,960 \mu \mathrm{S} / \mathrm{cm}$ at site 13 . Median specific conductance for individual sites ranged from $84 \mu \mathrm{S} / \mathrm{cm}$ at site 3 to $1,680 \mu \mathrm{S} / \mathrm{cm}$ at site 13 .

For all sites collectively, specific conductance showed strong positive correlations with DS (correlation coefficient of 0.94 ) and all major constituents $(0.71$ to 0.91$)$ except silica $(-0.19)$, no correlation to moderate positive correlations with nutrients $(0.09$ to 0.45$)$, and a moderate negative correlation with dissolved iron $(-0.60)$. For all sites collectively, specific conductance showed no correlation with instantaneous streamflow $(0.11)$, although for individual sites, the correlation between specific conductance and instantaneous streamflow ranged from no correlation to strongly negative $(-0.20$ to -0.85 ).

Specific conductance showed some seasonality especially at the sites where correlations with instantaneous streamflow were moderately to strongly negative. At most of these sites, specific conductance decreased during the late spring as flow increased from snowmelt and increased during the summer as flow decreased. For the other sites, the relation between specific conductance and instantaneous streamflow is altered or controlled by other natural or anthropogenic processes that are discussed in the sections on individual sites.

The $\mathrm{pH}$ measured at the basic-fixed sites ranged from $6.9 \mathrm{pH}$ units at site 3 to $9.3 \mathrm{pH}$ units at site 16 ; the median $\mathrm{pH}$ ranged from $7.8 \mathrm{pH}$ units at sites 1,3 , and 10 to $8.5 \mathrm{pH}$ units at site 11 . For all data collectively, $\mathrm{pH}$ had a moderate positive correlation with specific conductance (0.35) and most major constituents $(0.31$ to 0.38 ) except silica $(-0.07)$ and a moderate negative correlation with dissolved iron (-0.32), although the strength of the correlations varied among the individual sites. For the most part, $\mathrm{pH}$ did not exhibit seasonality.

The water at the basic-fixed sites was generally well oxygenated. Measured DO concentrations ranged from $3.5 \mathrm{mg} / \mathrm{L}$ at site 6 to $14.3 \mathrm{mg} / \mathrm{L}$ at site 10 ; median
DO concentrations ranged from $7.7 \mathrm{mg} / \mathrm{L}$ at site 12 to $9.3 \mathrm{mg} / \mathrm{L}$ at site 8 . Because the 100 -percent-saturation DO concentration strongly depends on water temperature, there was a moderate negative correlation between DO and water temperature $(-0.68)$ for the collective data and a strong negative correlation for most individual sites. Other properties and analytes showed no correlation with DO for the collective data. DO concentrations were very seasonal because of the relation between DO and water temperature.

Another way to express DO is percent of saturation. The 100-percent-saturation concentration of DO increases with decreasing water temperature and decreases with decreasing barometric pressure. The basic-fixed sites in the Colorado and northern New Mexico parts of the study unit are cooler and higher in altitude than the sites in the Chihuahuan Desert part of the study unit and have larger 100-percent-saturation concentrations of DO. The DO percent of saturation ranged from 49 at site 6 to 163 at site 6 ; the median DO percent of saturation ranged from 89 at site 12 to 108 at site 6 .

\section{Dissolved Solids and Major Constituents}

A graphical summary of the magnitudes of DS and major-constituent concentrations detected at the basic-fixed sites is presented in figure 2 . The box plots were calculated from base 10 logarithm transformations to accommodate the range of concentrations. The box plot for fluoride in figure 2 was truncated at the MRL by assigning the MRL value to any censored data.

Figure 2 shows that for DS and most major constituents the range of concentrations was greater than an order of magnitude and for some major constituents greater than two orders of magnitude. Of the cations, calcium had the largest median concentration $(39 \mathrm{mg} / \mathrm{L})$ and sodium had the largest maximum concentration $(460 \mathrm{mg} / \mathrm{L})$. Sodium also had the largest range for base 10 logarithm transformations (2.49 $\log$ units) and also for the non-transformed concentrations $(458.5 \mathrm{mg} / \mathrm{L})$. Of the anions, bicarbonate had the largest median concentration (120 $\mathrm{mg} / \mathrm{L})$ and sulfate had the largest maximum concentration $(1,200 \mathrm{mg} / \mathrm{L})$. Chloride had the largest range for base 10 logarithm transformations (3.18 log units) and sulfate had the largest range for nontransformed concentrations $(1,198.4 \mathrm{mg} / \mathrm{L})$. 


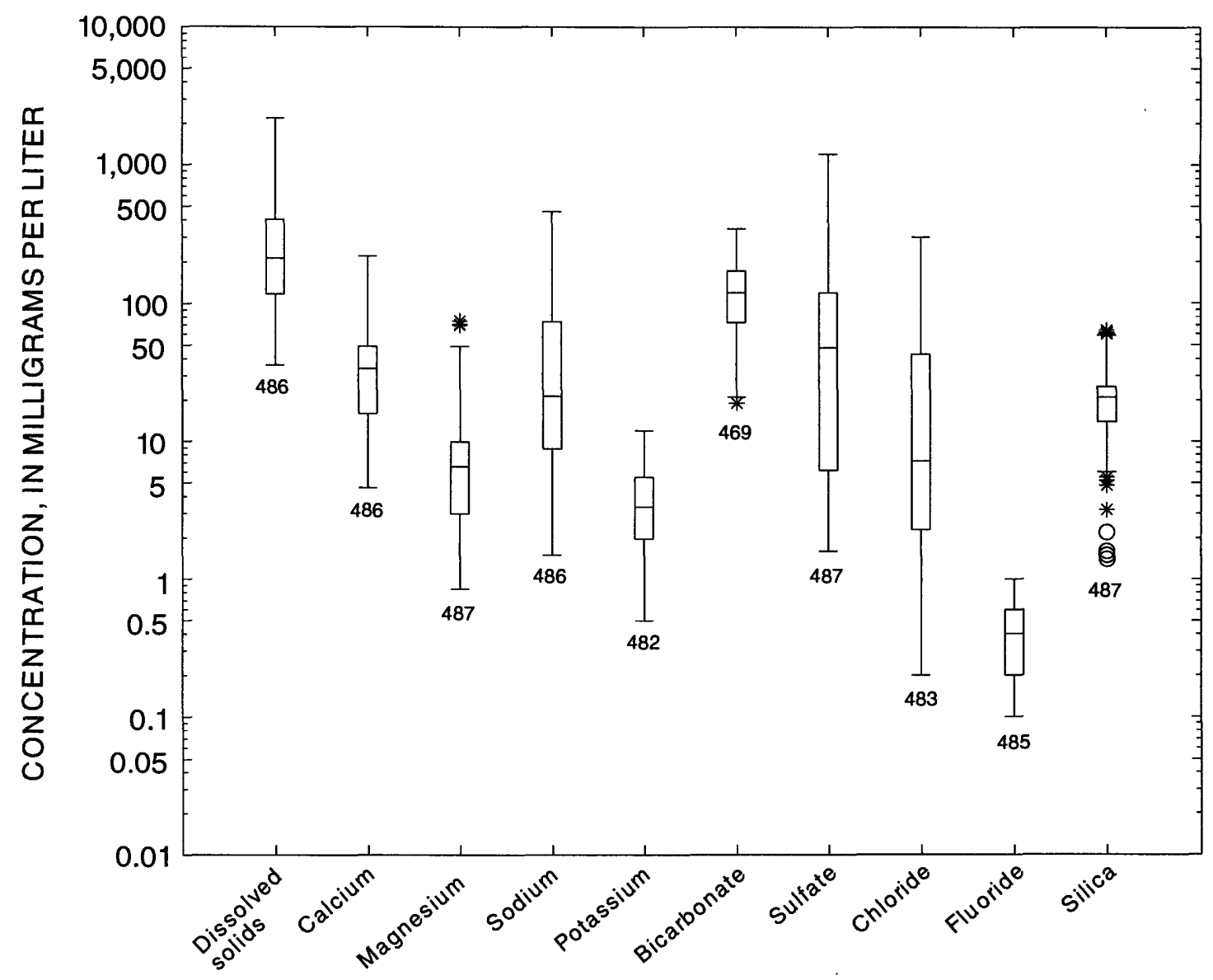

\section{EXPLANATION}

485 Number of samples

- Outlier data value more than 3 times the interquartile range outside the interquartile range

Outlier data value more than 1.5 times

* but less than or equal to 3 times the interquartile range outside the interquartile range

INTERQUARTILE RANGE $\left[\begin{array}{l}\text { Data value less than or equal to } 1.5 \text { times the } \\ \text { interquartile range outside the interquartile range } \\ \begin{array}{l}75 \text { th percentile } \\ \text { Median } \\ \text { 25th percentile }\end{array}\end{array}\right.$

Figure 2.--Dissolved-solids and major-constituent concentrations detected at basic-fixed sites. Box plot for fluoride truncated at minimum reporting level. 
The smallest median DS concentration at a basic-fixed site was $58 \mathrm{mg} / \mathrm{L}$ at site 3 . The largest median DS concentration at a basic-fixed site was $1,240 \mathrm{mg} / \mathrm{L}$ at site 13 . With the exception of silica, DS had strong positive correlations with all major constituents ( 0.70 to 0.93 ) and major constituents had moderate to strong positive correlations among themselves ( 0.58 to 0.93 ). Silica showed no correlation with DS $(-0.16)$ and showed no correlation to moderate negative correlations with the other major constituents $(-0.03$ to -0.32$)$.

The relation among DS and the major constituents can be seen in figure 3 . The size of the pie diagrams depicts the median DS concentrations. The upper semicircle of each pie diagram represents 100 percent of total milliequivalents per liter for the median cation concentrations, and the lower semicircle represents 100 percent of total milliequivalents per liter for the median anion concentrations. The sectors in each semicircle indicate the percentage of total cations or anions for that particular ion or pair of ions. The radius of the smaller concentric circle in each pie diagram represents the concentrations of silica relative to DS.

With the exception of site 4, DS concentrations generally increased in the main stem Rio Grande in a downstream direction. DS concentrations at site 1 were the smallest for a main-stem site and of the same magnitude as those at sites 2, 3, 5, and 10. The median DS concentration increased between site 1 and 4 ( 73 to $298 \mathrm{mg} / \mathrm{L}$ ); however, there is no direct correlation between concentrations at sites 1 and 4 . High flow at site 1 coincides with the irrigation season in the San Luis Valley: most flow at site 1 is diverted before it reaches site 4, and during parts of some years, no flow at site 1 reaches site 4 (Ralph Curtis, Rio Grande Water Conservation District, oral commun., 1996). The increase in DS at site 4 probably was due to a combination of natural and anthropogenic sources downstream from the irrigation diversions and evapotranspiration of the water in the main stem. The median DS concentration in the main stem decreased between sites 4 and 6 (298 to $191 \mathrm{mg} / \mathrm{L}$ ) because of dilution mainly from the inflow of the Conejos River. Between sites 6 and 7, the median DS concentration increased approximately 2 percent ( 191 to $194 \mathrm{mg} / \mathrm{L}$ ), but median instantaneous streamflow increased approximately 73 percent ( 365 to $633 \mathrm{ft}^{3} / \mathrm{s}$ ). This indicates that the median DS concentration of inflows in this reach was similar to the median concentration at site 6. The median DS concentration increased approximately 1 percent between sites 7 and 9 (194 to $196 \mathrm{mg} / \mathrm{L}$ ), and the median instantaneous streamflow increased approximately 118 percent ( 633 to 1,380 $\left.\mathrm{ft}^{3} / \mathrm{s}\right)$. This indicates that also in this reach the median DS concentration of the inflow was similar to that at site 7.

Downstream from site 9, the Rio Grande flows through Cochiti Lake; downstream from this reservoir, flow in the river is completely regulated. Downstream from Cochiti Dam, flow is diverted for irrigation, and the Rio Grande receives return flows from agricultural drains and flows past the Albuquerque urban area, from whence it receives urban runoff and discharges from point sources such as wastewater-treatment plants (WWTP's). Between sites 9 and 12, the median DS concentration in the main stem increased approximately 23 percent ( 196 to $242 \mathrm{mg} / \mathrm{L}$ ) and the median instantaneous streamflow decreased 8 percent $\left(1,380\right.$ to $\left.1,260 \mathrm{ft}^{3} / \mathrm{s}\right)$.

The median DS concentration at site 15 (299 $\mathrm{mg} / \mathrm{L}$ ) was approximately 24 percent larger than that at site $12(242 \mathrm{mg} / \mathrm{L})$, but the median instantaneous streamflow was approximately 23 percent smaller $\left(1,260\right.$ to $\left.975 \mathrm{ft}^{3} / \mathrm{s}\right)$. All tributaries in this reach are ephemeral and their contribution to instantaneous streamflow and DS concentration at site 15 is erratic. Most of the time, these tributaries will contribute little or no flow; at certain times, however, especially during the summer months when main-stem flow is low, discharge from one or more of these tributaries dominates DS concentrations at site 15 . In addition to inflow from natural tributaries, the Rio Grande receives irrigation-return flows and urban discharges in the upper part of this reach. In the lower part of the reach, most irrigation-return flows discharge to the conveyance channel (Bureau of Reclamation, 1977).

Between sites 15 and 16, the median DS concentration in the Rio Grande increased approximately 50 percent ( 299 to $448 \mathrm{mg} / \mathrm{L}$ ) and the median instantaneous streamflow decreased 6 percent ( 975 to $916 \mathrm{ft}^{3} / \mathrm{s}$ ). However, the hydrologic connection between these two sites has been highly altered by humans. The Rio Grande flows through Elephant Butte and Caballo Reservoirs, and streamflow is almost entirely regulated for irrigation downstream from Caballo Reservoir. During the nonirrigation season, no water is released from Caballo Reservoir and streamflow at site 16 is mainly from ground-water inflow. During the irrigation season, most streamflow 


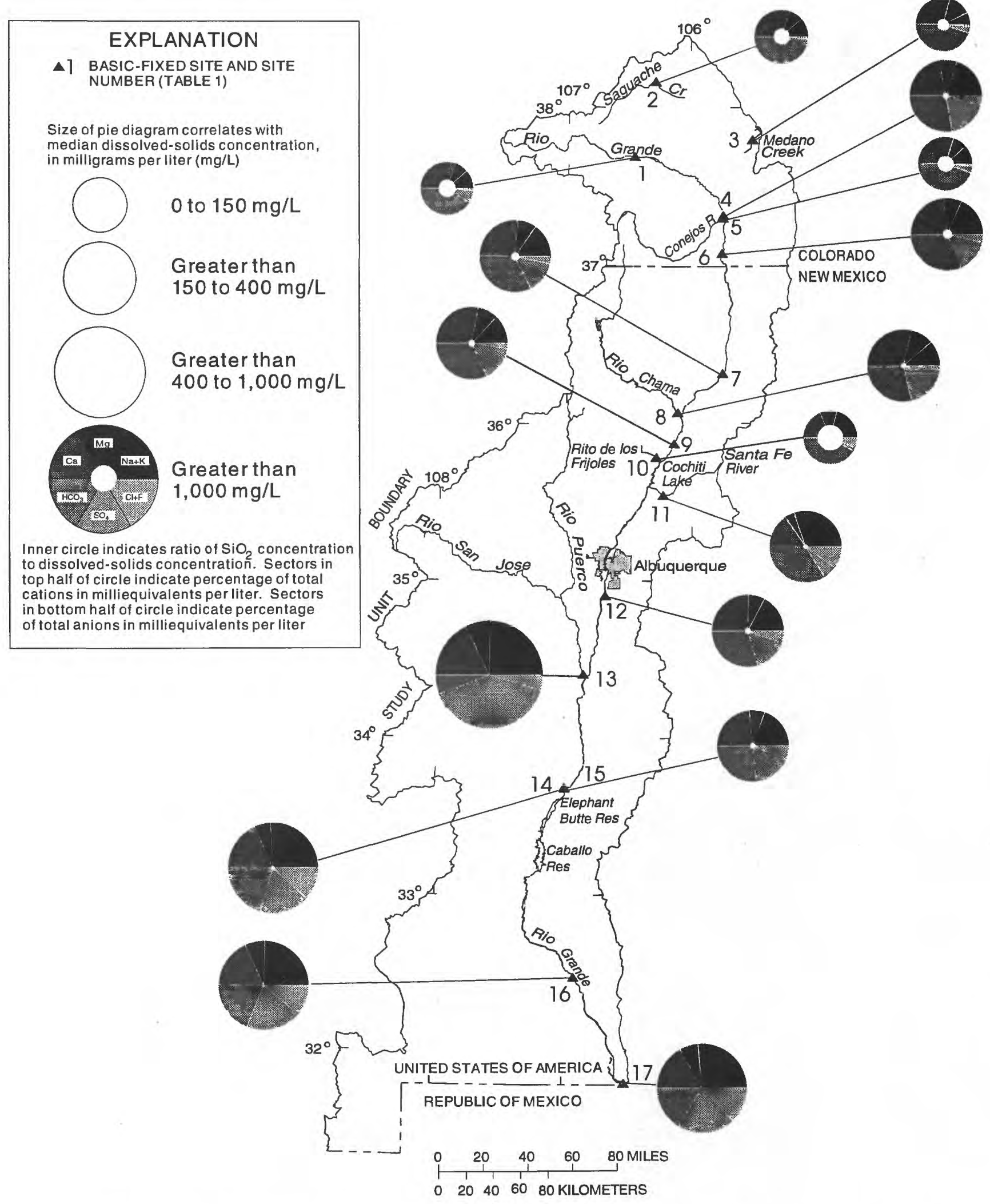

Figure 3.--Median dissolved-solids concentrations and major-constituent ratios at basic-fixed sites. 
at site 16 is water released from Caballo Reservoir plus some irrigation-return flow and ground-water inflow.

Between sites I6 and 17, the median DS concentration increased approximately 46 percent $(448$ to $652 \mathrm{mg} / \mathrm{L}$ ) and the median instantaneous streamflow decreased approximately 16 percent $\left(916\right.$ to $\left.770 \mathrm{ft}^{3} / \mathrm{s}\right)$. The streamflow regime is similar to that at site 16 except that a larger percentage of the flow is irrigationreturn flow. Point discharges and urban runoff may affect water quality in the river in this reach, and site 17 is located near the downstream end of an alluvial basin (Ellis and others, 1993) with the associated upwelling of ground water.

The spatial distribution of median calcium, magnesium, sodium, sulfate, chloride, and fluoride concentrations was similar to the spatial distribution of DS, although the relative differences in concentrations among sites varied for different constituents. For potassium, the major difference in spatial distribution was the decrease in median concentration from site 6 to site 9 . For bicarbonate, the largest median concentration was at site $11(239 \mathrm{mg} / \mathrm{L})$, and the median concentration at site $13(130 \mathrm{mg} / \mathrm{L})$ was approximately equal to that at site 12 (137 mg/L).

Of all cations, calcium and sodium had the largest concentrations at most basic-fixed sites. When comparing median concentrations in millieqivalents per liter, calcium was the predominant (greater than 50 percent of the total cation milliequivalents per liter) cation at sites 1-3, 5, 7-9, and 12. Sodium was the predominant cation at sites 11 and 17 . For the remainder of the sites, neither calcium nor sodium was predominant; however, calcium exceeded sodium in percentage of total cation milliequivalents per liter at sites 4,6 , and 15 , they were approximately equal at site 10 , and sodium exceeded calcium at sites 13,14, and 16. Site 3 differed from the other sites in that magnesium exceeded sodium.

Of all anions, bicarbonate and sulfate had the largest concentrations at most basic-fixed sites. Bicarbonate was the predominant anion at all sites except sites 13, 14, 16, and 17. Sulfate was the predominant anion at site 13 . Bicarbonate exceeded sulfate in percentage of total anion milliequivalents per liter at site 14, they were approximately equal at site 16 , and sulfate exceeded bicarbonate at site 17 . Sites 10 and 11 differed from the other sites in that chloride exceeded sulfate.
The median concentration of silica generally decreased at basic-fixed sites in a downstream direction. The spatial distribution of silica also differed from DS in that the median concentration at site 13 was the smallest $(7.8 \mathrm{mg} / \mathrm{L})$. The largest silica concentrations were detected at site 10 where the median concentration $(57 \mathrm{mg} / \mathrm{L})$ was approximately double the second largest median concentration (29 $\mathrm{mg} / \mathrm{L}$ at site 2 ). A noticeable decrease in silica between sites 15 and 16 may be due to biological uptake in Elephant Butte and Caballo Reservoirs.

Silica accounts for approximately 50 percent of the DS at site 10, which is located on a tributary that drains a basin that is predominantly underlain by volcanic tuff. Silica was also a large part of DS at sites 1,2 , and 5 where it accounted for approximately 30 percent of the DS and at site 3 where it accounted for approximately 20 percent of the DS. For the remaining sites, silica concentration as a percentage of DS concentration generally decreased downstream as the concentration of DS increased.

\section{Nutrients}

A graphical summary of the magnitudes of nutrient concentrations at the basic-fixed sites is presented in figure 4 . The box plots were calculated from base 10 logarithm transformations to accommodate the range of concentrations. All box plots in figure 4 were truncated at the MRL for that analyte by assigning the MRL value to any censored data. The box plot for dissolved nitrite $\left(\mathrm{NO}_{2}\right)$ is a straight line at the MRL concentration because more than 75 percent of $\mathrm{NO}_{2}$ values were censored. The box plot for dissolved ammonia plus organic nitrogen is truncated above the median line because more than 50 percent of dissolved ammonia plus organic nitrogen values were censored.

Figure 4 shows that the range of nutrient concentrations was greater than an order of magnitude and for some nutrients greater than two orders of magnitude. The large number of outliers are due to relatively large concentrations at specific sites.

The largest concentrations and largest median concentrations for the dissolved-nutrient analytes were at sites 11 and 12 . Site 11 is a tributary indicator site for urban land use and site 12 is a main-stem integrator site downstream from the Albuquerque area. The relatively large dissolved-nutrient concentrations at these sites probably were due to discharges from WWTP's and 

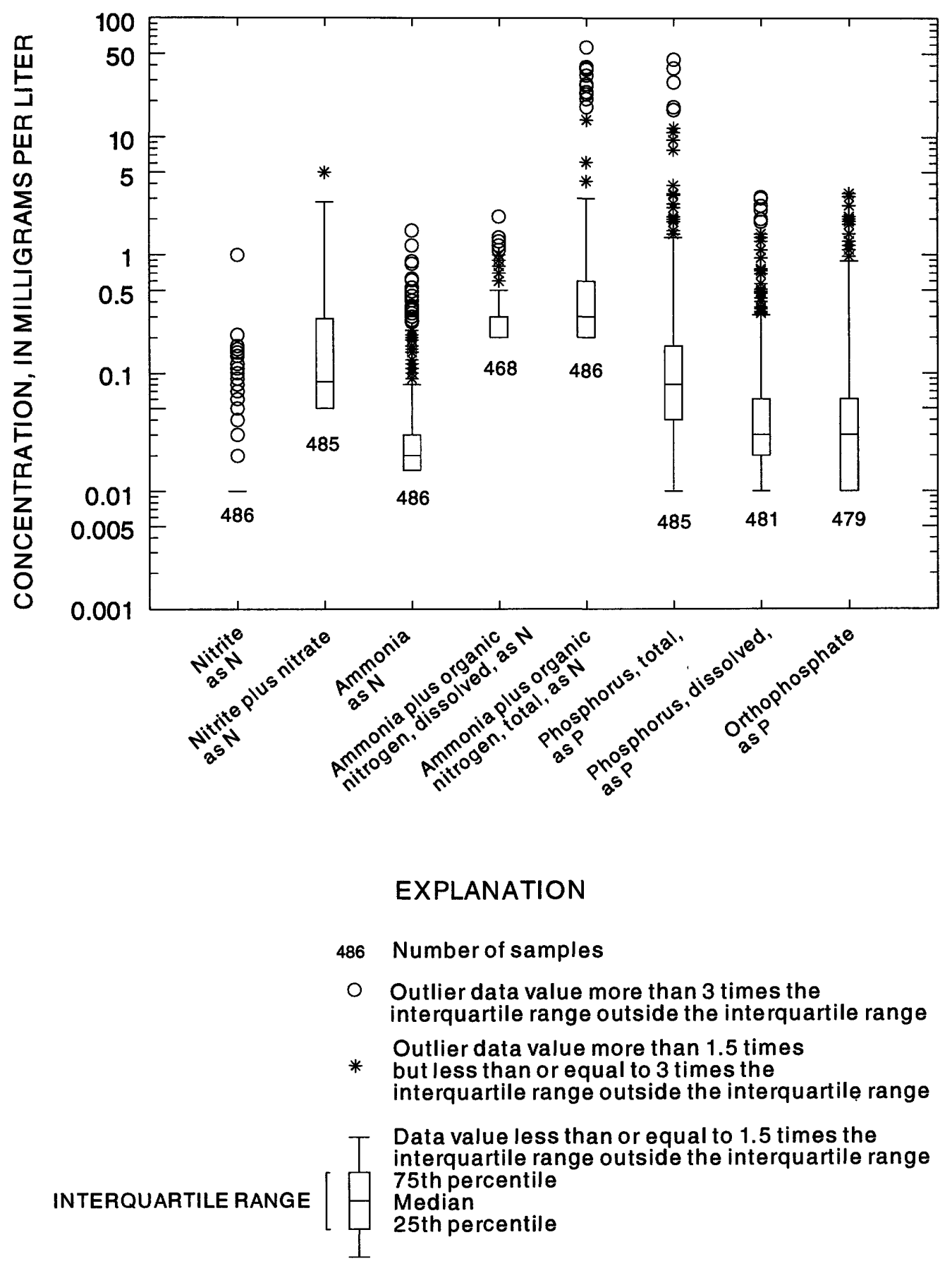

Figure 4.--Nutrient concentrations detected at basic-fixed sites. Box plots for all nutrient analytes truncated at their respective minimum reporting levels. 
urban runoff. The second largest median concentration for dissolved nitrite plus nitrate $\left(\mathrm{NO}_{2}+\mathrm{NO}_{3}\right)$ was at site 13 , an integrator site on an ephemeral tributary. The larger concentrations of $\mathrm{NO}_{2}+\mathrm{NO}_{3}$ at this site were associated with runoff from summer thunderstorms. The source of this $\mathrm{NO}_{2}+\mathrm{NO}_{3}$ is probably atmospheric deposition and animal manure on the rangeland upstream from this site (Anderholm and others, 1995).

The largest concentrations and largest median concentrations of total ammonia plus organic nitrogen and total phosphorus were at site 13. As with $\mathrm{NO}_{2}+$ $\mathrm{NO}_{3}$, the largest concentrations of these nutrients at this site were associated with runoff from summer thunderstorms. Relatively large concentrations of both total nutrient analytes were detected at sites 11 and 15 . Most total nutrient analytes at site 11 were in the dissolved phase and associated with WWTP discharges and urban runoff; the largest concentrations of both total nutrients at this site, however, were associated with runoff from snowmelt. The largest concentrations of both total nutrient analytes at site 15 were associated with runoff from ephemeral tributaries.

For all sites collectively, the nutrients showed no correlation to moderate positive correlations with specific conductance ( 0.09 to 0.45 ), and the major constituents (-0.02 to 0.48$)$. $\mathrm{NO}_{2}+\mathrm{NO}_{3}$ showed a moderate negative correlation with dissolved iron (-0.37). Among themselves, most nutrients showed no correlation to moderate positive correlations $(0.24$ to 0.69 ), and because most of the dissolved phosphorus is orthophosphate, dissolved phosphorus and orthophosphate showed a strong positive correlation (0.81).

The spatial distribution of $\mathrm{NO}_{2}+\mathrm{NO}_{3}$ concentrations at the basic-fixed sites is presented in figure 5 . The size of the pie diagrams correlates with median $\mathrm{NO}_{2}+\mathrm{NO}_{3}$ concentrations. The sites that had the smaller median concentrations (sites 1-3, 5, 6, 8, and 10) were all located in Colorado and northern $\mathrm{New}$ Mexico. More than 75 percent of the $\mathrm{NO}_{2}+\mathrm{NO}_{3}$ concentrations at sites $2,5,8$, and 10 and more than 50 percent of the concentrations at sites 1,3 , and 6 were censored. Site 4 had the largest median concentration $(0.06 \mathrm{mg} / \mathrm{L})$ in the Colorado part of the study unit probably due to the anthropogenic discharges upstream from this site. The increase in $\mathrm{NO}_{2}+\mathrm{NO}_{3}$ concentrations between sites 6 and 7 probably were due to a combination of mineralization/nitrification of organic nitrogen in the main stem, ground-water inflow containing a larger $\mathrm{NO}_{2}+\mathrm{NO}_{3}$ concentration to the main stem and tributaries, and irrigation-return flow and WWTP discharges to tributaries. The large decrease in $\mathrm{NO}_{2}+\mathrm{NO}_{3}$ concentration between sites 15 and 16 was probably due to denitrification or uptake by biota in Elephant Butte and Caballo Reservoirs.

\section{Dissolved Iron and Dissolved Manganese}

Dissolved-iron concentrations ranged from censored values at sites 13-17 to 914 micrograms per liter $(\mu \mathrm{g} / \mathrm{L})$ at site 13 . The range of median concentrations was from $3 \mu \mathrm{g} / \mathrm{L}$ at sites 16 and 17 to $160 \mu \mathrm{g} / \mathrm{L}$ at site 2 . Dissolved-manganese concentrations ranged from censored concentrations at sites $13-17$ to $300 \mu \mathrm{g} / \mathrm{L}$ at site 4 . The range of median concentrations was from $1 \mu \mathrm{g} / \mathrm{L}$ at site 15 to $68 \mu \mathrm{g} / \mathrm{L}$ at site 4.

For all sites collectively, dissolved iron showed a moderate negative correlation with specific conductance $(-0.60), \mathrm{pH}(-0.32)$, DS $(-0.58)$, the major constituents $(-0.43$ to -0.62$)$ except silica $(0.26)$, and $\mathrm{NO}_{2}+\mathrm{NO}_{3}(-0.37)$ and a moderate positive correlation with dissolved manganese (0.35). Dissolved manganese showed no correlation with all other properties and analytes except dissolved iron and silica (0.34).

Dissolved iron and dissolved manganese differed from DS, major constituents, and nutrients in that the larger median concentrations were detected in Colorado and northern New Mexico. The five sites where the largest median dissolved-iron concentrations were detected (sites 1-3, 5, and 10) are the same sites where the smallest median DS concentrations were detected. Hem (1985) stated that a flowing surface stream that is fully aerated should not contain more than a few micrograms per liter of uncomplexed dissolved iron at equilibrium. The relatively large dissolved-iron concentrations at these five sites may be due to particulates that passed through the 0.45 -micron filter (Kennedy and others, 1974). The dissolvedmanganese concentrations at sites 4,5 , and 6 , as a group, were significantly larger (greater than a 99 percent confidence level) than the concentrations at the other basic-fixed sites. 


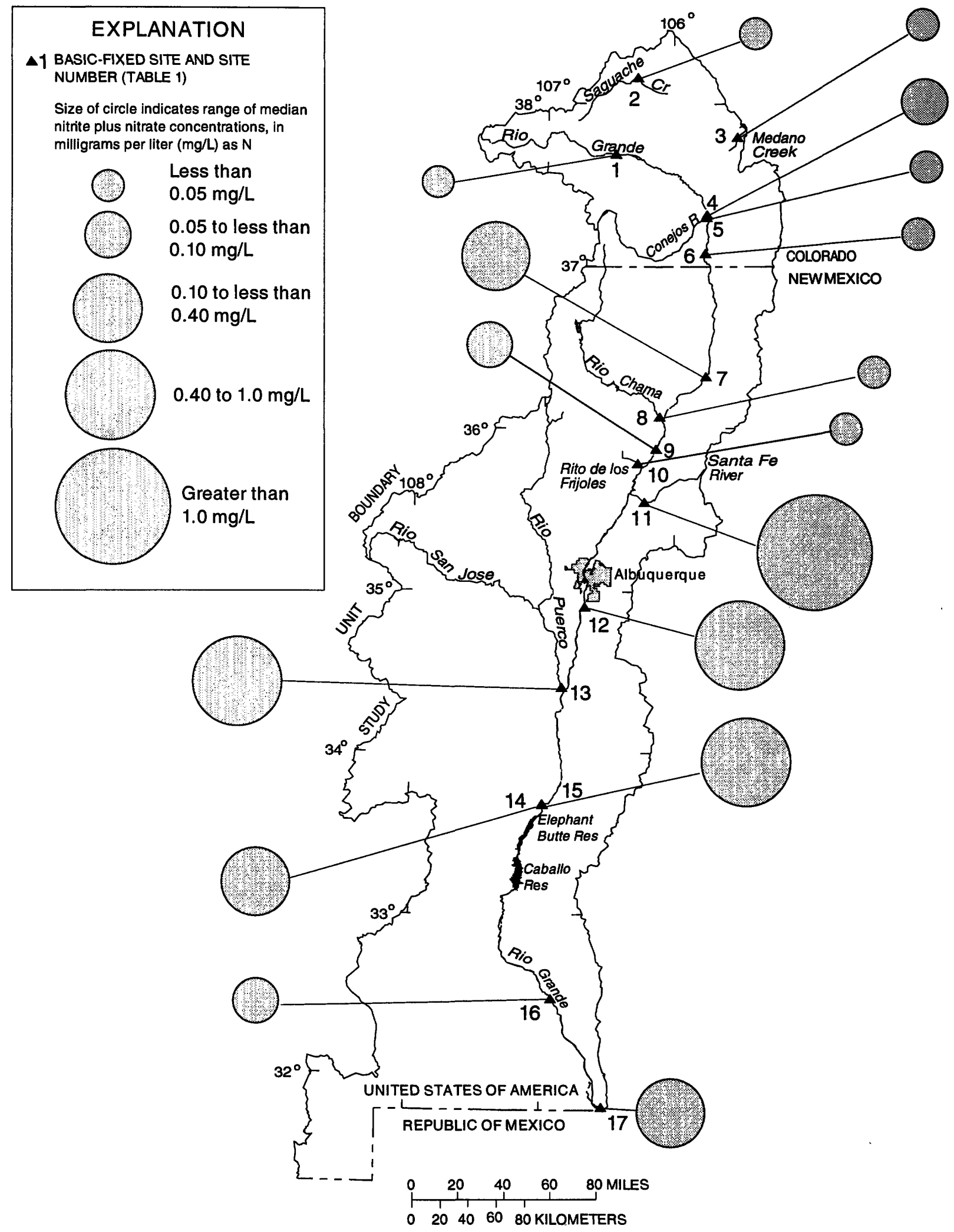

Figure 5.--Median dissolved nitrite plus nitrate concentrations detected at basic-fixed sites. 


\section{Summary and Analysis by Basic-Fixed Site}

In this section, water-quality data for individual sites are presented in summary statistics tables. The tables are accompanied by a short description of the site location and drainage-basin characteristics upstream from the site and an analysis of the water quality at the site. Each section also contains a table of regression equations relating selected field properties and time to DS and major-constituent and nutrient analytes that have less than 20 percent censored values. In general the discussion follows the sites in a downstream direction in the watershed.

In the discussion on water quality, the median concentrations of individual analytes are grouped into low, middle, and high groups. This grouping system was developed as a reference system for readers who are not familiar with water quality in the upper Rio Grande Valley and wonder how analyte concentrations at individual sites compared with similar concentrations at other basic-fixed sites. For each analyte, the sites were ranked in order from 1 to 17 ; the site having the smallest median concentration was ranked 1 and the site having the largest median concentration was ranked 17 . Sites with the same median concentration were assigned the average rank for those sites--that is, if two sites had the same median concentration and would have been assigned ranks 4 and 5 , both sites were assigned rank 4.5. Sites with ranks from 1 to 5 were assigned to the low group, sites with ranks from 6 to 12 were assigned to the middle group, and sites with ranks 13 to 17 were assigned to the high group. Ranks that equaled 5.5 were rounded to 6 and assigned to the middle group; ranks that equaled 12.5 were rounded to 12 and assigned to the middle group. Special consideration was given to median concentrations that were censored data. These median concentrations were assigned values equal to one-half the MDL and used to rank the uncensored median concentrations for that analyte. In the discussion, however, these uncensored median concentrations are not included in any group, but are mentioned as being below the MDL for that analyte.

\section{Site 1 - Rio Grande near Del Norte, Colo.}

Site 1, the most upstream integrator site on the main stem of the Rio Grande, is approximately $6 \mathrm{mi}$ west of Del Norte, Colorado. The streamflow-gaging station at this site is operated by the Colorado Division of Water Resources (CDWR) and is located on the right bank about $20 \mathrm{ft}$ downstream from the bridge on county road 17. Low-flow samples were collected by wading downstream from the bridge, and high-flow samples were collected from a cableway located approximately 0.25 mi upstream from the bridge.

Upstream from this site, the Rio Grande drains a $1,310-\mathrm{mi}^{2}$ mountainous basin that is mainly forest and rangeland (U.S. Geological Survey, 1986). This basin includes areas of historical mining activity, the largest of which centers around Creede, Colorado, approximately $30 \mathrm{mi}$ upstream from site 1 . Major bedrock types in the drainage basin are Tertiary tuff and lava (Tweto, 1979).

Streamflow at this site varies seasonally. High flows, which occur in the late spring and early summer, result mainly from snowmelt in the San Juan

Mountains. Late summer and early autumn storms may cause some high flows, but these flows have neither the magnitude nor duration of the high spring flows. Upstream reservoirs regulate flow somewhat, and there are some small diversions for irrigation and some transmountain diversions from the Colorado River Basin to the Rio Grande Basin. The annual mean discharge at site 1 for water years (WY's) 1890 to 1995 was $908 \mathrm{ft}^{3} / \mathrm{s}$ (Crowfoot and others, 1996). The annual mean discharge for WY 1993 was $900 \mathrm{ft}^{3} / \mathrm{s}$ (Ugland and others, 1994); for WY 1994 was $722 \mathrm{ft}^{3} / \mathrm{s}$ (Ugland and others, 1995); and for WY 1995 was $1,164 \mathrm{ft}^{3} / \mathrm{s}$ (Crowfoot and others, 1996). A water year starts October 1 of the previous calendar year and ends September 30 of the calendar year by which it is identified.

The water sampled at site 1 was a welloxygenated, calcium bicarbonate type. The median specific-conductance value was 87 , the median $\mathrm{pH}$ value was 7.8 , and the median DO percent of saturation was 98 . DS and most major constituents were in the low group; silica was in the middle group. The median magnesium and bicarbonate concentrations were the smallest for any basic-fixed site. The median concentrations of all nitrogen nutrients were below their respective MDL's, whereas the phosphorous nutrients were in the middle group. Dissolved iron was in the high group; dissolved-iron concentrations were larger than expected for well-oxygenated surface waters (Hem, 1985), possibly due to particulates and/or colloids that passed through a 0.45 -micron filter (Kennedy and others, 1974). Dissolved manganese was also in the high group. Summary statistics for field- 
property and chemical-analyte data for site 1 are presented in table 5 .

Specific conductance $(-0.81)$ and DS (-0.74) showed strong negative correlations with streamflow; the major constituents showed moderate negative to strong negative correlations with streamflow ( -0.43 to $0.85)$. High flows in late spring and early summer had the lowest concentrations of DS and major constituents. $\mathrm{NO}_{2}+\mathrm{NO}_{3}$ showed a moderate negative correlation with streamflow $(-0.62)$. For this nitrogen analyte, high-flow concentrations were below the MRL and low-flow concentrations were above the MRL. Dissolved iron showed a moderate positive correlation with streamflow (0.49), whereas dissolved manganese showed a moderate negative correlation $(-0.57)$. Regression equations that relate selected water-quality data to selected field properties and time are presented in table 6.

\section{Site 2 - Saguache Creek near Saguache, Colo.}

Site 2 is an indicator site for a small forested basin on a stream that is not a tributary to the Rio Grande. Saguache Creek drains parts of the La Garita Mountains and Cochetopa Hills of the San Juan Mountains and discharges into the San Luis Closed Basin. The streamflow-gaging station at this site is operated by the CDWR and is located on private land approximately $10 \mathrm{mi}$ northwest of Saguache, Colorado. Low-flow samples were collected by wading upstream from the gage, and high-flow samples were collected from a cableway about $25 \mathrm{ft}$ downstream from the gage.

Upstream from site 2, the Saguache Creek Basin has a 512-mi drainage area that is mainly forest and rangeland (U.S. Geological Survey, 1986). Some abandoned mines are in the basin and the site itself is near fields that are sporadically used for grazing livestock. Major bedrock types in the basin are Tertiary tuff and lava (Tweto, 1979).

Streamflow at this site is seasonal; most high flows result from snowmelt in the late spring and early summer. The Tarbell Ditch transmountain diversion discharges into the basin upstream from the gage. Some water is diverted from the creek for irrigation, also upstream from the gage. The annual mean discharge at site 2 for WY's 1910 to 1995 was $68.1 \mathrm{ft}^{3} / \mathrm{s}$ (Crowfoot and others, 1996). The annual mean discharge for WY 1993 was $66.9 \mathrm{ft}^{3} / \mathrm{s}$ (Ugland and others, 1994); for WY 1994 was $45.7 \mathrm{ft}^{3} / \mathrm{s}$ (Ugland and others, 1995); and for WY 1995 was $82.4 \mathrm{ft}^{3} / \mathrm{s}$ (Crowfoot and others, 1996).
The water sampled at site 2 was a welloxygenated, calcium bicarbonate type. The median specific-conductance value was 126 , the median $\mathrm{pH}$ value was 8.0 , and the median DO percent of saturation was 103. DS and most major constituents were in the low group; silica was in the high group. About 25 percent of the samples contained silica concentrations above the common range for surface waters, 1 to 30 $\mathrm{mg} / \mathrm{L}$ (Hem, 1985). The larger concentrations of silica were detected during the winter months and were probably the result of a larger percentage of the streamflow that is older ground water from the volcanic tuffs. The median concentrations of all dissolvednitrogen nutrients were below their respective MDL's. The median concentration of total ammonia plus organic nitrogen was at the MDL, $0.2 \mathrm{mg} / \mathrm{L}$ as N, which is in the middle group for the RIOG basic-fixed sites. Total phosphorus was in the middle group; dissolved phosphorus and orthophosphate were in the high group. Dissolved iron was in the high group; dissolved-iron concentrations were larger than expected for well-oxygenated surface waters (Hem, 1985), possibly due to particulates and/or colloids that passed through a 0.45 -micron filter (Kennedy and others, 1974). Dissolved manganese was also in the high group. Summary statistics for field-property and chemical-analyte data for site 2 are presented in table 7.

Streamflow did not correlate strongly with any field property or chemical analyte. Samples collected during the two highest streamflows, however, contained the largest concentrations of DS, sodium, magnesium, potassium, dissolved ammonia plus organic nitrogen, total ammonia plus organic nitrogen, iron, and manganese detected at this site. These samples also were among those that had the largest concentrations of calcium, bicarbonate, and sulfate. Regression equations that relate selected water-quality data to selected field properties and time are presented in table 8 .

\section{Site 3 - Medano Creek near Mosca, Colo.}

Site 3 is an indicator reference site for a small forested basin on Medano Creek, which is not a tributary to the Rio Grande. Medano Creek drains part of the west slope of the Sangre de Cristo Range and discharges into the San Luis Closed Basin along the eastern edge of the dune field in Great Sand Dunes National Monument, Colorado. The site is located approximately $5 \mathrm{mi}$ north of the monument's visitor 


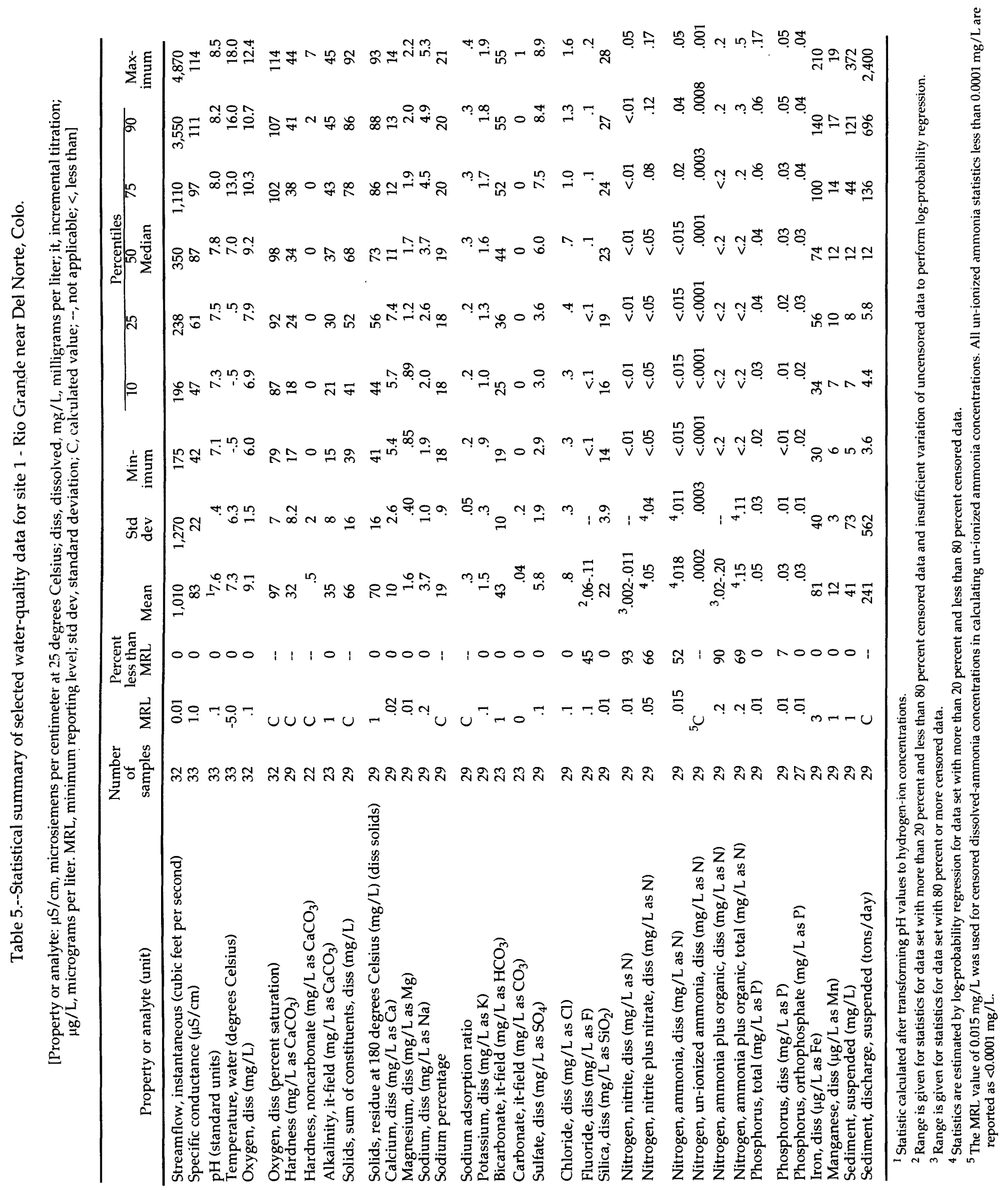


Table 6.--Regression equations for selected water-quality analytes with selected field properties and time for site 1 - Rio Grande near Del Norte, Colo.

[Analyte: ${ }^{\circ} \mathrm{C}$, degrees Celsius; diss, dissolved; ortho, orthophosphate. Unit: $\mathrm{mg} / \mathrm{L}$, milligrams per liter; $\mu \mathrm{g} / \mathrm{L}$, micrograms per liter. Regression equation: sclog, base 10 logarithm of specific conductance, in microsiemens per centimeter at $25^{\circ} \mathrm{C}$; temp, water temperature, in ${ }^{\circ} \mathrm{C}$; sea ${ }^{1}$, seasonality variable; sc, specific conductance, in microsiemens per centimeter at $25^{\circ} \mathrm{C}$; DOlog, base 10 logarithm of dissolvedoxygen concentration, in $\mathrm{mg} / \mathrm{L}$; qlog, base 10 logarithm of streamflow, in cubic feet per second; $\mathrm{pH}$, in standard $\mathrm{pH}$ units; $\mathrm{DO}$, dissolved-oxygen concentration, in $\mathrm{mg} / \mathrm{L}$; $\mathrm{q}$, streamflow, in cubic feet per second. Adj $R^{2}$, adjusted coefficient of determination (Ott, 1993). Method: MLR, multiple linear regression;

KTR, Kendall-Theil robust line. --, not applicable]

\begin{tabular}{|c|c|c|c|c|}
\hline Analyte & Unit & Regression equation & Adj $R^{2}$ & Method \\
\hline $\begin{array}{l}\text { Solids, residue at } 180^{\circ} \mathrm{C} \\
\text { (dissolved solids) }\end{array}$ & $\mathrm{mg} / \mathrm{L}$ & $10^{(0.218+0.855 \text { sclog }-0.003 \text { temp }+0.025 \text { sea })}$ & 0.919 & MLR \\
\hline Calcium & $\mathrm{mg} / \mathrm{L}$ & $10^{(-0.984+1.034 \mathrm{sclog}+0.007 \mathrm{sea})}$ & .989 & MLR \\
\hline Magnesium & $\mathrm{mg} / \mathrm{L}$ & $10^{(-2.234+0.070 \mathrm{qlog}+1.129 \mathrm{sclog}+0.027 \mathrm{pH}-0.012 \mathrm{DO}-0.004 \text { temp })}$ & .980 & MLR \\
\hline \multirow[t]{2}{*}{ Sodium } & $\mathrm{mg} / \mathrm{L}$ & 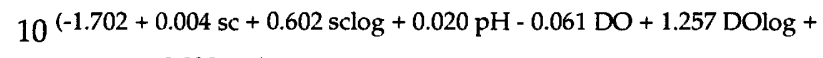 & & \\
\hline & & +0.020 sea) & .984 & MLR \\
\hline Potassium & $\mathrm{mg} / \mathrm{L}$ & $10^{(-1.163+0.698 \mathrm{sclog}+0.021 \mathrm{sea})}$ & .757 & MLR \\
\hline Bicarbonate, as $\mathrm{HCO}_{3}$ & $\mathrm{mg} / \mathrm{L}$ & $10^{(-0.377+1.033 \mathrm{sclog})}$ & .924 & MLR \\
\hline Sulfate, as $\mathrm{SO}_{4}$ & $\mathrm{mg} / \mathrm{L}$ & $10^{(-0.123+0.006 \mathrm{sc}+0.071 \mathrm{pH}-0.019 \mathrm{DO}-0.007 \text { temp })}$ & .965 & MLR \\
\hline Chloride & $\mathrm{mg} / \mathrm{L}$ & $10^{(-2.719+1.400 \text { sclog }-0.021 \text { temp }+0.104 \text { sea })}$ & .810 & MLR \\
\hline Silica, as $\mathrm{SiO}_{2}$ & $\mathrm{mg} / \mathrm{L}$ & $8.220+0.0007 q+0.207 s c-4.488$ DOlog & .955 & MLR \\
\hline Phosphorus, total, as $\mathrm{P}$ & $\mathrm{mg} / \mathrm{L}$ & $-1.232+0.00005 q-0.088 q \log -0.005 s c+0.999 s c \log$ & .548 & MLR \\
\hline $\begin{array}{l}\text { Phosphorus, diss, as } \mathrm{P} \\
\text { Phosphorus, ortho, }\end{array}$ & $\mathrm{mg} / \mathrm{L}$ & ${ }^{2} 0.03$ & -- & KTR \\
\hline diss, as $\mathrm{P}$ & $\mathrm{mg} / \mathrm{L}$ & $10^{(-4.836+0.252 \mathrm{qlog}+1.380 \mathrm{sclog})}$ & .379 & MLR \\
\hline Iron, diss & $\mu \mathrm{g} / \mathrm{L}$ & $-3,352+0.022 q+124.2 q \log -8.969 s c+2,004 \mathrm{sclog}$ & .742 & MLR \\
\hline Manganese, diss & $\mu \mathrm{g} / \mathrm{L}$ & $10^{(1.392-0.111 \mathrm{q} \log -0.046 \mathrm{sea})}$ & .589 & MLR \\
\hline
\end{tabular}

${ }^{1}$ sea $=\sin (T)+\cos (T)$ where $T$ equals the time, in months, from December 1, 1992, times 0.5236 .

${ }^{2}$ The slope coefficient of the Kendall-Theil robust line between dissolved phosphorus and water temperature is equal to zero. 


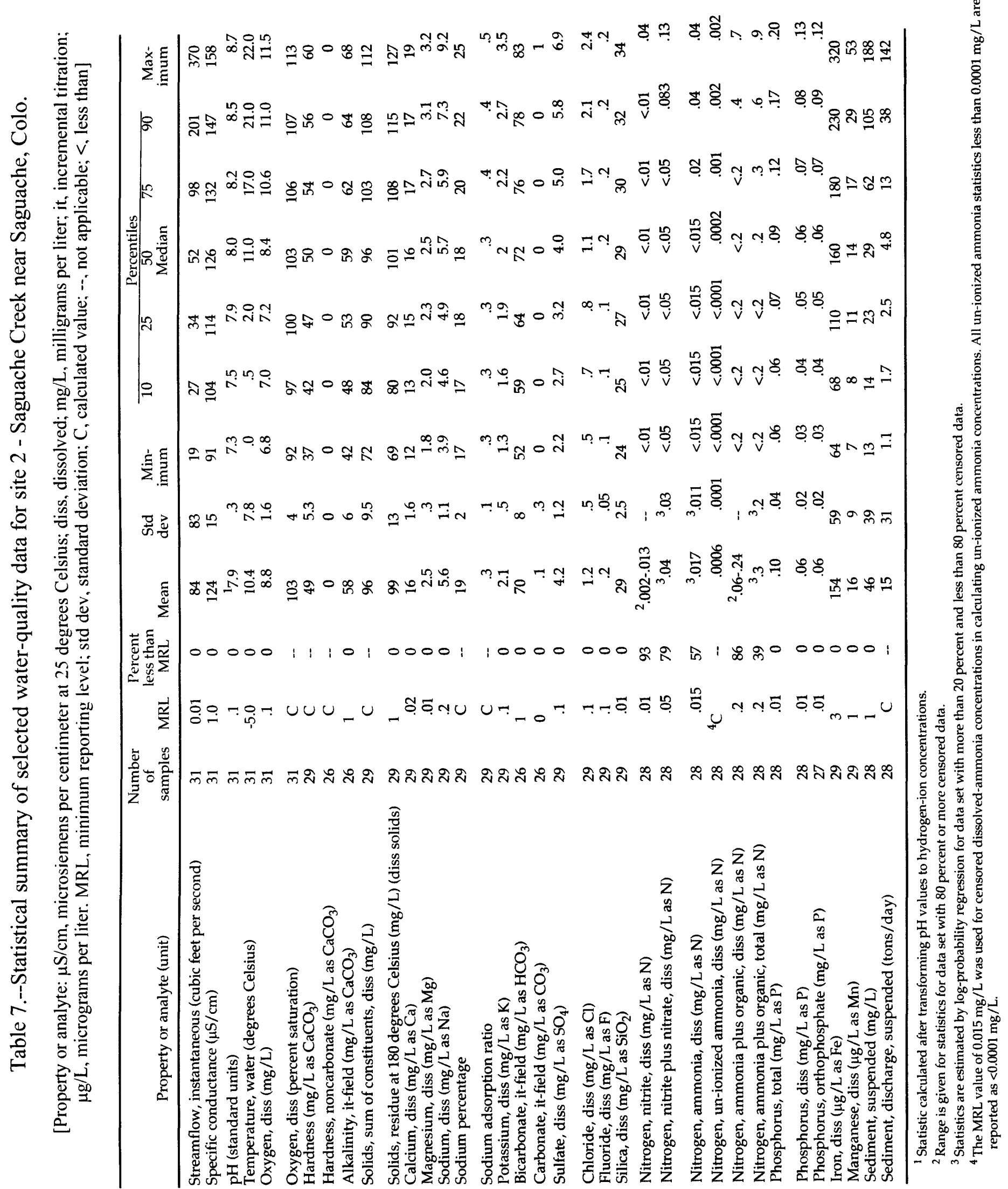


Table 8.--Regression equations for selected water-quality analytes with selected field properties and time for site 2 - Saguache Creek near Saguache, Colo.

[Analyte: ${ }^{\circ} \mathrm{C}$, degrees Celsius: diss, dissolved; ortho, orthophosphate. Unit: $\mathrm{mg} / \mathrm{L}$, milligrams per liter; $\mu \mathrm{g} / \mathrm{L}$, micrograms per liter. Regression equation: sc, specific conductance, in microsiemens per centimeter at $25^{\circ} \mathrm{C}$ : sclog, base 10 logarithm of specific conductance, in microsiemens per centimeter at $25^{\circ} \mathrm{C}$; qlog, base 10 logarithm of streamflow, in cubic feet per second; DO, dissolved-oxygen concentration, in $\mathrm{mg} / \mathrm{L}$; q, streamflow, in cubic feet per second; DOlog, base 10 logarithm of dissolved-oxygen concentration, in $\mathrm{mg} / \mathrm{L} ; \mathrm{pH}$, in standard $\mathrm{pH}$ units; sea ${ }^{1}$, seasonality variable. Adj $\mathrm{R}^{2}$, adjusted coefficient of determination (Ott, 1993). Method: MLR, multiple linear regression]

\begin{tabular}{|c|c|c|c|c|}
\hline Analyte & Unit & Regression equation & Adj $R^{2}$ & Method \\
\hline $\begin{array}{l}\text { Solids, residue at } 180^{\circ} \mathrm{C} \\
\text { (dissolved solids) }\end{array}$ & $\mathrm{mg} / \mathrm{L}$ & $4.649+0.753 \mathrm{sc}$ & 0.617 & MLR \\
\hline Calcium & $\mathrm{mg} / \mathrm{L}$ & $10^{(-0.524+0.729 \mathrm{sclog}+0.024 \mathrm{pH})}$ & .702 & MLR \\
\hline Magnesium & $\mathrm{mg} / \mathrm{L}$ & $-11.13+0.257 \mathrm{q} \log +6.278 \mathrm{sclog}$ & .795 & MLR \\
\hline Sodium & $\mathrm{mg} / \mathrm{L}$ & $69.19+0.780 \mathrm{qlog}+0.227 \mathrm{sc}-44.940 \mathrm{sclog}+0.092 \mathrm{DO}$ & .890 & MLR \\
\hline Potassium & $\mathrm{mg} / \mathrm{L}$ & $-1.070+0.0016 q+0.024 s c$ & .674 & MLR \\
\hline Bicarbonate, as $\mathrm{HCO}_{3}$ & $\mathrm{mg} / \mathrm{L}$ & $10^{(-5.506+0.049 q \log -0.012 \mathrm{sc}+4.088 \mathrm{sclog}+0.172 \mathrm{DOlog})}$ & .701 & MLR \\
\hline Sulfate, as $\mathrm{SO}_{4}$ & $\mathrm{mg} / \mathrm{L}$ & $75.55-0.0072 q+2.336 q \log +0.278 \mathrm{sc}$ & 832 & MI R \\
\hline Chloride & $\mathrm{mg} / \mathrm{L}$ & $10^{(-7.329+0.009 \mathrm{sc}-0.549 \mathrm{DO}+11.880 \mathrm{DOlog})}$ & .623 & MLR \\
\hline Fluoride & $\mathrm{mg} / \mathrm{L}$ & $-1.214+0.514 \mathrm{sclog}+0.038 \mathrm{pH}$ & .340 & MLR \\
\hline Silica, as $\mathrm{SiO}_{2}$ & $\mathrm{mg} / \mathrm{L}$ & $10^{(1.051+0.001 \mathrm{sc}+0.032 \mathrm{pH}-0.028 \mathrm{sea})}$ & .733 & MLR \\
\hline Phosphorus, total, as $\mathrm{P}$ & $\mathrm{mg} / \mathrm{L}$ & $-6.29+0.002 q-0.014 \mathrm{sc}+4.045 \mathrm{sclog}-0.039 \mathrm{pH}+0.025 \mathrm{sea}$ & .414 & MLR \\
\hline Phosphorus, diss, as $\mathrm{P}$ & $\mathrm{mg} / \mathrm{L}$ & $0.311+0.0003 q-0.064 q \log -0.167$ DOlog & .447 & MLR \\
\hline $\begin{array}{l}\text { Phosphorus, ortho, } \\
\text { diss, as } \mathrm{P}\end{array}$ & $\mathrm{mg} / \mathrm{L}$ & $0.307+0.0003 q-0.063 q \log -0.165$ DOlog & .540 & MLR \\
\hline Iron, diss & $\mu \mathrm{g} / \mathrm{L}$ & $10^{(5.22+0.0016 q-0.466 q \log -0.206 \mathrm{pH}-0.082 \mathrm{DO})}$ & .516 & MLR \\
\hline Manganese, diss & $\mu \mathrm{g} / \mathrm{L}$ & $10^{(1.841+0.0006 q+0.007 s c-0.186 p H-0.015 \text { temp }+0.129 \text { sea })}$ & .531 & MLR \\
\hline
\end{tabular}

${ }^{\prime}$ sea $=\sin (T)+\cos (T)$ where $T$ equals the time, in months, from December 1, 1992, times 0.5236 . 
center at a streamflow-gaging station and flume operated by the National Park Service (NPS). All samples were collected upstream from the flume.

Land use in the $15-\mathrm{mi}^{2}$ drainage basin upstream from site 3 is forest and alpine tundra (U.S. Geological Survey, 1986). A jeep trail that follows the creek, some campsites, and a diversion from the creek to another basin for irrigation are the main anthropogenic effects in this basin. Major bedrock types in this basin are Precambrian granite and gneiss and Pennsylvanian and Permian sedimentary rock (Tweto, 1979).

No long-term streamflow records are available for site 3; however, during the high-intensity sampling phase, streamflow at site 3 was seasonal: high flows occurred in late spring and early summer in conjunction with snowmelt in the Sangre de Cristo Range. The annual mean discharge in WY 1994 was smaller than in WY 1993, and in WY 1995 it was larger than in the 2 previous years.

The water sampled at site 3 was a welloxygenated. calcium bicarbonate type. The median specific-conductance value was 84 , the median $\mathrm{pH}$ value was 7.8 , and the median DO percent of saturation was 100. DS and the major constituents were in the low group; the median concentrations of DS, chloride, potassium, and sodium were the smallest for any basicfixed site. The mean chloride concentration of 0.49 $\mathrm{mg} / \mathrm{L}$ was approximately 5.6 times larger than the weighted monthly mean chloride concentration in precipitation of $0.087 \mathrm{mg} / \mathrm{L}$ during the high-intensity sampling phase for this area, and the mean sulfate concentration of $3.1 \mathrm{mg} / \mathrm{L}$ was approximately 4.2 times larger than the weighted monthly mean sulfate concentration of $0.736 \mathrm{mg} / \mathrm{L}$ (National Atmospheric Deposition Program, 1996). With the exception of total phosphorus, the median concentrations of all nutrients were below their respective MDL's. The median concentration of total phosphorus was at the MDL of $0.01 \mathrm{mg} / \mathrm{L}$; this median concentration was the smallest for any basic-fixed site. Dissolved iron was in the high group; dissolved-iron concentrations were larger than expected for well-oxygenated surface waters (Hem, 1985), possibly due to particulates and/or colloids that passed through a 0.45 -micron filter (Kennedy and others, 1974). Dissolved manganese was in the middle group. Summary statistics for field-property and chemical-analyte data for site 3 are presented in table 9 .

Specific conductance $(-0.85)$, DS (-0.54), and most major constituents ( -0.36 to -0.82$)$ except potassium $(-0.19)$ showed moderate to strong negative correlations with streamflow, whereas nutrients showed no correlation to moderate positive correlations ( -0.06 to 0.56$)$. The smallest concentrations of DS and most major constituents and the largest concentrations of total phosphorus and total ammonia plus organic nitrogen were detected during the high flows in late spring and early summer. Dissolved-iron concentrations showed two annual peaks: the first during high flows in late spring and early summer and the second during low flows in late summer and early autumn. This latter peak appears to be associated with the annual die off of vegetation. Regression equations that relate selected water-quality data to selected field properties and time are presented in table 10 .

\section{Site 4 - Rio Grande above mouth of Trinchera Creek, near Lasauses, Colo.}

Site 4 is an integrator site on the main stem approximately $3.2 \mathrm{mi}$ north of Lasauses, Colorado. The streamflow-gaging station for this site is operated by the CDWR and is located approximately $0.5 \mathrm{mi}$ upstream from a bridge on $Z$ Road. Low-flow samples were collected by wading between the gage and the bridge, and high-flow samples were collected from a cableway about $100 \mathrm{ft}$ downstream from the gage. Because of anthropogenic alterations to the channel of Trinchera Creek, most of its flow enters the Rio Grande upstream from the gaging station (Ugland and others, 1994).

Between sites 1 and 4, the Rio Grande flows through the San Luis Valley skirting the edge of the San Luis Closed Basin. Major land uses in the $1,440-\mathrm{mi}^{2}$ contributing drainage basin between the two sites are forest and rangeland along the headwaters of the tributaries that flow from the San Juan Mountains and Sangre de Cristo Range; land use becomes predominantly agricultural in the valley (U.S. Geological Survey, 1986). Upstream from site 4, the WWTP for the city of Alamosa, Colorado, and the Franklin Eddy Canal discharge to the river. The Franklin Eddy Canal is the conveyance channel used by the Bureau of Reclamation (BOR) to deliver water from the unconfined aquifer in the San Luis Closed Basin to the Rio Grande (Elfrink and others, 1989). The Alamosa National Wildlife Refuge is located along this reach of the Rio Grande, and some abandoned mining areas are along the headwaters of tributaries in the San Juan Mountains and Sangre de Cristo Range. Major 


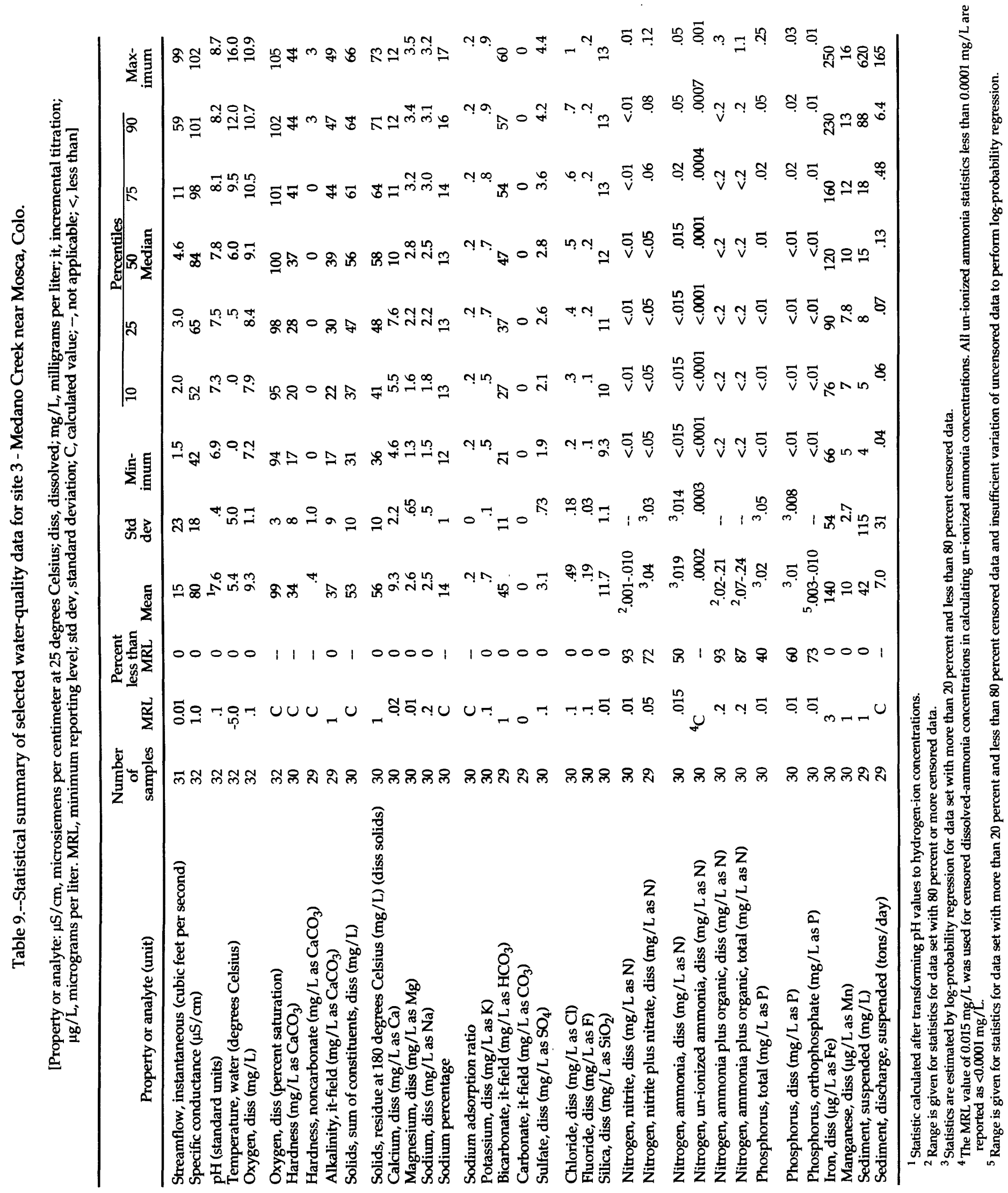


Table 10.--Regression equations for selected water-quality analytes with selected field properties and time for site 3 - Medano Creek near Mosca, Colo.

[Analyte: ${ }^{\circ} \mathrm{C}$, degrees Celsius; diss, dissolved. Unit: $\mathrm{mg} / \mathrm{L}$, milligrams per liter; $\mu \mathrm{g} / \mathrm{L}$, micrograms per liter. Regression equation: qlog, base 10 logarithm of streamflow, in cubic feet per second; sc, specific conductance, in microsiemens per centimeter at $25^{\circ} \mathrm{C}$; sea $\mathrm{e}^{1}$, seasonality variable; sclog, base 10 logarithm of specific conductance, in microsiemens per centimeter at $25^{\circ} \mathrm{C} ; \mathrm{pH}$, in standard $\mathrm{pH}$ units; temp, water temperature, in ${ }^{\circ} \mathrm{C}$; q, streamflow, in cubic feet per second; DOlog, base 10 logarithm of dissolved-oxygen concentration, in $\mathrm{mg} / \mathrm{L}$; DO, dissolved-oxygen concentration, in $\mathrm{mg} / \mathrm{L}$. Adj $\mathrm{R}^{2}$, adjusted coefficient of determination (Ott, 1993). Method: MLR, multiple linear regression]

\begin{tabular}{|c|c|c|c|c|}
\hline Analyte & Unit & Regression equation & Adj $R^{2}$ & Method \\
\hline $\begin{array}{l}\text { Solids, residue at } 180^{\circ} \mathrm{C} \\
\text { (dissolved solids) }\end{array}$ & $\mathrm{mg} / \mathrm{L}$ & $10^{(-0.648+0.0023 q+1.245 \mathrm{sclog}+0.035 \mathrm{sea})}$ & 0.723 & MLR \\
\hline Calcium & $\mathrm{mg} / \mathrm{L}$ & $10^{(-0.705-0.0008 q+0.885 \text { sclog })}$ & .960 & MLR \\
\hline Magnesium & $\mathrm{mg} / \mathrm{L}$ & $10^{(-2.323-0.003 \mathrm{sc}+1.464 \mathrm{sclog}+0.024 \mathrm{pH}-0.002 \text { temp })}$ & .980 & MLR \\
\hline Sodium & $\mathrm{mg} / \mathrm{L}$ & $10^{(-1.717+0.0010 q+1.117 \text { sclog }-0.003 \text { temp } p+0.028 \text { sea })}$ & .949 & MLR \\
\hline Potassium & $\mathrm{mg} / \mathrm{L}$ & $10^{(-3.147+0.0025 q-0.016 s c+3.326 \text { sclog }-2.037 \text { DOlog }-0.020 \text { temp })}$ & .470 & MLR \\
\hline Bicarbonate, as $\mathrm{HCO}_{3}$ & $\mathrm{mg} / \mathrm{L}$ & $\left.10^{(-2.992+0.0018 q-0.008 s c+2.771 s c l o g}\right)$ & .931 & MLR \\
\hline Sulfate, as $\mathrm{SO}_{4}$ & $\mathrm{mg} / \mathrm{L}$ & $10^{(-2.588+0.002 q+1.089 \mathrm{sclog}+0.080 \mathrm{pH}+0.036 \mathrm{DO}+0.032 \text { sea })}$ & .778 & MLR \\
\hline Chloride & $\mathrm{mg} / \mathrm{L}$ & $10^{(-3.46+0.338 \mathrm{q} \log +2.008 \mathrm{sclog}-0.111 \mathrm{pH}-0.018 \text { temp })}$ & .670 & MLR \\
\hline Fluoride & $\mathrm{mg} / \mathrm{L}$ & $0.19-0.002 q+0.022 q \log$ & .723 & MLR \\
\hline Silica, as $\mathrm{SiO}_{2}$ & $\mathrm{mg} / \mathrm{L}$ & $\left.10^{(-2.476+0.0022 q-0.010 s c+2.276 s c l o g}\right)$ & .683 & MLR \\
\hline Iron, diss & $\mu \mathrm{g} / \mathrm{L}$ & $-638.6+207.32 q \log +881.59 \mathrm{sclog}-103.27 \mathrm{DO}-19.29$ temp & .670 & MLR \\
\hline Manganese, diss & $\mu \mathrm{g} / \mathrm{L}$ & $10^{(-1.079+0.302 \mathrm{qlog}+1.205 \mathrm{sclog}-0.047 \mathrm{DO}-0.137 \mathrm{sea})}$ & .658 & MLR \\
\hline
\end{tabular}

${ }^{1}$ sea $=\sin (T)+\cos (T)$ where $T$ equals the time, in months, from December 1, 1992, times 0.5236. 
surficial deposits and bedrock types are unconsolidated gravel, sand, and silt in the San Luis Valley and Tertiary lava and tuff along the headwaters of the tributaries originating in the San Juan Mountains (Tweto, 1979).

The natural streamflow pattern at site 4 has been highly altered by diversions for irrigation between sites 1 and 4 . Flows at site 4 are still high during the late spring and early summer, but the magnitude of these flows is much smaller than it would be under natural conditions. Drainage from irrigated land, discharges from the WWTP and Franklin Eddy Canal, and flowing wells that tap the confined aquifer beneath the San Luis Valley augment the streamflow at site 4 . Only during the winter months are the flows at site 4 larger than those at site 1 . The annual mean discharge at site 4 for WY's 1936 to 1995 was $268 \mathrm{ft}^{3} / \mathrm{s}$ (Crowfoot and others, 1996). The annual mean discharge for WY 1993 was $253 \mathrm{ft}^{3} / \mathrm{s}$ (Ugland and others, 1994); for WY 1994 was $194 \mathrm{ft}^{3} / \mathrm{s}$ (Ugland and others, 1995); and for WY 1995 was $394 \mathrm{ft}^{3} / \mathrm{s}$ (Crowfoot and others, 1996).

The water sampled at site 4 for the most part was a well-oxygenated, calcium sodium bicarbonate type. During high spring flows, sulfate exceeded bicarbonate in percentage of total anion milliequivalents per liter, and in four samples sodium exceeded calcium in percentage of total cation milliequivalents per liter. The median specific-conductance value was 456 , the median $\mathrm{pH}$ value was 8.2 , and the median $\mathrm{DO}$ percent of saturation was 100 .

Mainly because of anthropogenic influences upstream, DS and most major-constituent concentrations at this site were significantly larger than their comparative concentrations at any other basicfixed site in the Colorado part of the RIOG study unit. The larger concentrations of DS and most major constituents occurred just prior to and on the falling limb of the high spring flows when nearly all the river is diverted upstream from site 4 . These diversions reduce natural flow, allowing anthropogenic discharges to dominate the water quality at site 4 . DS and most major constituents were in the high part of the middle group for all RIOG basic-fixed sites; bicarbonate, magnesium, silica, and sulfate were in the high group.

With the exception of $\mathrm{NO}_{2}$, the nitrogen nutrient concentrations at site 4 also were significantly larger than at any other site in the Colorado part of the RIOG study unit; $\mathrm{NO}_{2}$ concentrations for the most part were censored. $\mathrm{NO}_{2}+\mathrm{NO}_{3}$ concentrations were larger in the winter than in the summer when most concentrations were censored, whereas concentrations of dissolved ammonia, dissolved ammonia plus organic nitrogen, and total ammonia plus organic nitrogen were larger in the summer months. The smaller $\mathrm{NO}_{2}+\mathrm{NO}_{3}$ concentrations during the summer months probably were due to uptake of these nitrogen analytes by aquatic bryophytes and algae. Most nutrients were in the middle group; dissolved ammonia, dissolved ammonia plus organic nitrogen, and dissolved phosphorus were in the high group.

Dissolved iron was in the middle group, whereas dissolved manganese was in the high group. The median dissolved-manganese concentration was the largest for any basic-fixed site; dissolved-manganese concentrations were significantly larger than those at any other basic-fixed site. These concentrations increased with increasing flow but tended to decrease before peak flow was reached. Summary statistics for field-property and chemical-analyte data for site 4 are presented in table 11. Regression equations that relate selected water-quality data to selected field properties and time are presented in table 12.

\section{Site 5 - Conejos River near Lasauses, Colo.}

Site 5 is an integrator site on a tributary that originates in the San Juan Mountains and discharges to the Rio Grande approximately 2.1 mi north of Lasauses, Colorado. The streamflow-gaging station for this site is operated by the CDWR and is located about $125 \mathrm{ft}$ downstream from a bridge on 28th Road. Lowflow samples were collected by wading, and high-flow samples were collected from the upstream side of the bridge. When water was flowing in the Conejos River diversion, which flows under 28th Road approximately $1 \mathrm{mi}$ south of Conejos River, a sample from the river and from the diversion was collected and composited for site 5. During August 1993, the main Conejos River channel was straightened upstream from the bridge.

Land use in the $789-\mathrm{mi}^{2}$ Conejos River Basin is predominantly forest in the headwater areas and rangeland and agricultural in the San Luis Valley (U.S. Geological Survey, 1986). The headwater areas also contain a number of historical mining areas. Major bedrock types and surficial deposits in the Conejos River Basin are Tertiary tuff, lava, and conglomerate in the headwater areas and unconsolidated gravel, sand, and silt in the San Luis Basin (Dane and Bachman, 1965; Tweto, 1979).

Streamflow at site 5 is seasonal; high flows occur in the late spring and early summer. A storage 


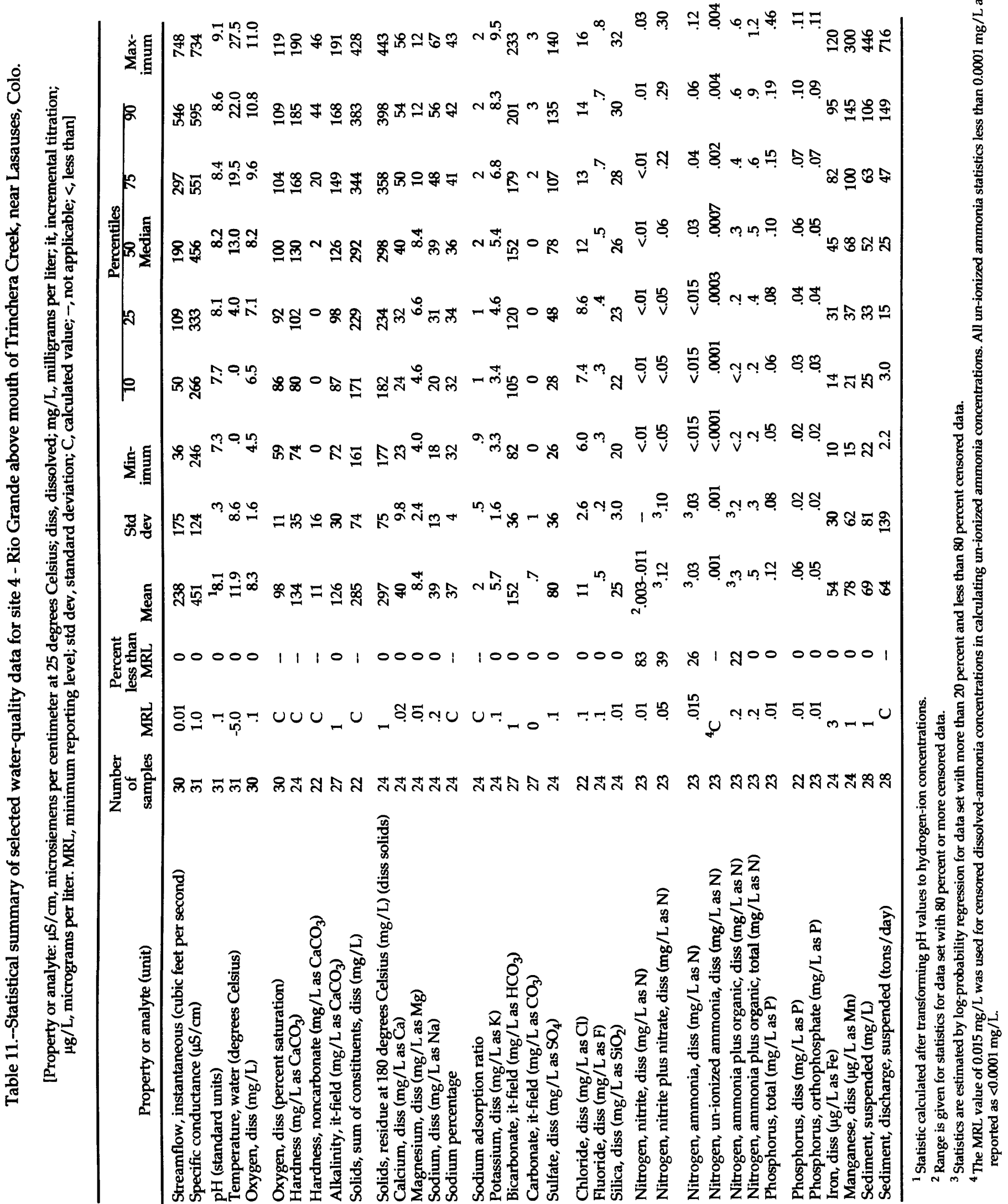


Table 12.--Regression equations for selected water-quality analytes with selected field properties and time for site 4 - Rio Grande above mouth of Trinchera Creek, near Lasauses, Colo.

[Analyte: ${ }^{\circ} \mathrm{C}$, degrees Celsius; anm + org, ammonia plus organic; diss. dissolved; ortho, orthophosphate. Unit: $\mathrm{mg} / \mathrm{L}$, milligrams per liter; $\mu \mathrm{g} / \mathrm{L}$, micrograms per liter. Regression equation: sc, specific conductance, in microsiemens per centimeter at $25^{\circ} \mathrm{C}$; sclog, base 10 logarithm of specific conductance, in microsiemens per centimeter at $25^{\circ} \mathrm{C}$; qlog, base 10 logarithm of streamflow, in cubic feet per second; $\mathrm{DO}$, dissolved-oxygen concentration, in $\mathrm{mg} / \mathrm{L}$; $\mathrm{sea}^{1}$, seasonality variable; $\mathrm{q}$, streamflow, in cubic feet per second; $\mathrm{pH}$, in standard $\mathrm{pH}$ units; temp, water temperature, in ${ }^{\circ} \mathrm{C}$; DOlog, base 10 logarithm of dissolvedoxygen concentration, in mg/L. Adj $\mathrm{R}^{2}$, adjusted coefficient of determination (Ott, 1993). Method: MLR, multiple linear regression]

\begin{tabular}{|c|c|c|c|c|}
\hline Analyte & Unit & Regression equation & Adj $R^{2}$ & Method \\
\hline $\begin{array}{l}\text { Solids, residue at } 180^{\circ} \mathrm{C} \\
\text { (dissolved solids) }\end{array}$ & $\mathrm{mg} / \mathrm{L}$ & $10^{(1.212+0.0006 s c+0.372 s c l o g)}$ & 0.974 & MLR \\
\hline Calcium & $\mathrm{mg} / \mathrm{L}$ & $10^{(-0.750+0.888 \mathrm{sclog})}$ & .922 & MLR \\
\hline Magnesium & $\mathrm{mg} / \mathrm{L}$ & $10^{(-3.288+0.046 \mathrm{qlog}-0.0006 \mathrm{sc}+1.653 \mathrm{sclog})}$ & .958 & MLR \\
\hline Sodium & $\mathrm{mg} / \mathrm{L}$ & $10^{(-1.625+1.212 \mathrm{sclog})}$ & .944 & MLR \\
\hline Potassium & $\mathrm{mg} / \mathrm{L}$ & $10^{(0.296+0.001 \mathrm{sc})}$ & .911 & MLR \\
\hline Bicarbonate, as $\mathrm{HCO}_{3}$ & $\mathrm{mg} / \mathrm{L}$ & $109.0+0.286 \mathrm{sc}-9.541 \mathrm{DO}-21.692 \mathrm{sea}$ & .734 & MLR \\
\hline Sulfate, as $\mathrm{SO}_{4}$ & $\mathrm{mg} / \mathrm{L}$ & $10^{(-3.175+0.128 \mathrm{q} \log +1.799 \mathrm{sclog})}$ & .940 & MLR \\
\hline Chloride & $\mathrm{mg} / \mathrm{L}$ & $10^{(-1.787+1.072 \text { sclog }-0.042 \text { sea })}$ & .817 & MLR \\
\hline Fluoride & $\mathrm{mg} / \mathrm{L}$ & $10^{(-1.622-0.0002 q+0.0008 \mathrm{sc}-0.226 \mathrm{DO}+3.281 \text { DOlog }-0.009 \text { temp })}$ & .812 & MLR \\
\hline Silica, as $\mathrm{SiO}_{2}$ & $\mathrm{mg} / \mathrm{L}$ & $25.82-2.302$ sea & .611 & MLR \\
\hline $\begin{array}{l}\text { Nitrogen, amm + org, } \\
\text { total, as } \mathrm{N}\end{array}$ & $\mathrm{mg} / \mathrm{L}$ & $10^{(-1.180+0.986 \mathrm{sclog}-0.229 \mathrm{pH}+0.010 \text { temp })}$ & .683 & MLR \\
\hline Phosphorus, total, as $\mathrm{P}$ & $\mathrm{mg} / \mathrm{L}$ & $10^{(1.149-0.287 \mathrm{pH}+0.019 \text { temp })}$ & .449 & MLR \\
\hline $\begin{array}{l}\text { Phosphorus, diss, as } \mathrm{P} \\
\text { Phosphorus, ortho, diss, }\end{array}$ & $\mathrm{mg} / \mathrm{L}$ & $0.64-0.040 \mathrm{pH}+0.040 \mathrm{DO}-0.688 \mathrm{DOlog}+0.003$ temp & .734 & MLR \\
\hline $\begin{array}{l}\text { as } \mathrm{P} \\
\text { Iron, diss }\end{array}$ & $\begin{array}{l}\mathrm{mg} / \mathrm{L} \\
\mu \mathrm{g} / \mathrm{L}\end{array}$ & $\begin{array}{l}1.12+0.034 \mathrm{qlog}+0.0005 \mathrm{sc}-0.440 \mathrm{sclog}-0.244 \text { DOlog }-0.01 \\
259.2+0.044 \mathrm{q}+88.80 \mathrm{sclog}-54.90 \mathrm{pH}\end{array}$ & $\begin{array}{r}\text { sea } .653 \\
.503\end{array}$ & $\begin{array}{l}\text { MLR } \\
\text { MLR }\end{array}$ \\
\hline Manganese, diss & $\mu \mathrm{g} / \mathrm{L}$ & $10^{(-9.575-0.006 \mathrm{sc}+7.273 \mathrm{sclog}-0.644 \mathrm{pH})}$ & .478 & MLR \\
\hline
\end{tabular}

${ }^{1}$ sea $=\sin (T)+\cos (T)$ where $T$ equals the time, in months, from December 1, 1992, times 0.5236 . 
reservoir in the upper basin and diversions for irrigation alter streamflow at the site. During some years, such as 1994, site 5 may have no streamflow in late summer. The annual mean discharge at site 5 for WY's 1921 to 1995 was $187 \mathrm{ft}^{3} / \mathrm{s}$ (Crowfoot and others, 1996). The annual mean discharge for WY 1993 was $261 \mathrm{ft}^{3} / \mathrm{s}$ (Ugland and others, 1994); for WY 1994 was $184 \mathrm{ft}^{3} / \mathrm{s}$ (Ugland and others, 1995); and for WY 1995 was $313 \mathrm{ft}^{3} / \mathrm{s}$ (Crowfoot and others, 1996).

The water sampled at site 5 was a welloxygenated, calcium bicarbonate type. The median specific-conductance value was 124 , the median $\mathrm{pH}$ value was 7.9, and the median DO percent of saturation was 96. DS and most major constituents were in the low group; potassium was in the middle group; and silica was in the high group. About 33 percent of the samples contained silica concentrations above the common range for surface waters, 1 to $30 \mathrm{mg} / \mathrm{L}$ (Hem, 1985). These relatively large silica concentrations were detected in late summer when streamflow was lowest and was composed of a larger percentage of ground water from flowing wells or springs (Siebenthal, 1910). Silica concentrations during the remainder of the year probably were the result of weathering of volcanic tuffs in the drainage basin. The median concentrations of the nitrogen nutrients were below their respective MDL's. Total phosphorus was in the low group; dissolved phosphorus and orthophosphate were in the middle group. Dissolved iron and dissolved manganese were in the high group.

Specific conductance $(-0.58)$, DS (-0.57), and most major constituents $(-0.34$ to 0.67$)$ showed moderate negative correlations to streamflow; silica showed a strong negative correlation to streamflow $(-0.71)$. The smallest concentrations of DS and the major constituents occurred annually during high spring flows. Dissolved-iron concentrations showed a moderate positive correlation with streamflow (0.62); the largest concentrations were detected during high spring flows, possibly due to particulates and/or colloids that passed through a 0.45 -micron filter (Kennedy and others, 1974). In contrast, dissolvedmanganese concentrations showed a moderate negative correlation with streamflow $(-0.39)$, and the largest concentrations were detected in the late summer of 1994 when streamflow approached zero. Summary statistics for field-property and chemical-analyte data for site 5 are presented in table 13. Regression equations that relate selected water-quality data to selected field properties and time are presented in table 14.

\section{Site 6 - Rio Grande near Lobatos, Colo.}

Site 6 is an integrator site on the main stem approximately $11 \mathrm{mi}$ east of Lobatos, Colorado. The streamflow-gaging station for this site is operated by the CDWR and is located just downstream from a bridge on G Road. Low-flow samples were collected by wading upstream from the bridge, and high-flow samples were collected from the upstream side of the bridge.

Between sites 4 and 6, the Rio Grande flows through the lower part of the San Luis Valley, draining an area of approximately $1,830 \mathrm{mi}^{2}$. Approximately 43 percent of this area is in the Conejos River Basin. Major land uses in this reach, excluding the Conejos River Basin, are forest in the headwaters of tributaries and rangeland and agricultural in the valley (U.S. Geological Survey, 1986). Major surficial deposits and bedrock types are Tertiary lava, breccia, tuff, and conglomerate and Quaternary unconsolidated gravel and alluvium (Tweto, 1979).

Streamflow at site 6 is seasonal: flow is high in late spring and early summer. These high flows may result from high flows on the main stem (site 4) or on the Conejos River (site 5) or may be a summation of smaller flows on both; very little discharge reaches the river from the basin east of the Rio Grande. During WY 1993, the high spring flow at site 6 was mainly from the Conejos River; during WY 1994, the high spring flow was a summation of main-stem and Conejos River flows: and during WY 1995, the high spring flow was initially from the Conejos River. As this flow started to recede, high flow started on the main stem, and the final WY 1995 peak flow at site 6 was a summation of mainstem and Conejos River flows. Streamflow at other times was composed mainly of main-stem water. The annual mean discharge at site 6 for WY's 1931 to 1995 was $452 \mathrm{ft}^{3} / \mathrm{s}$ (Crowfoot and others, 1996). The annual mean discharge for WY 1993 was $535 \mathrm{ft}^{3} / \mathrm{s}$ (Ugland and others, 1994); for WY 1994 was $399 \mathrm{ft}^{3} / \mathrm{s}$ (Ugland and others, 1995); and for WY 1995 was $742 \mathrm{ft}^{3} / \mathrm{s}$ (Crowfoot and others, 1996).

The water sampled at site 6 for the most part was a well-oxygenated, calcium sodium bicarbonate type. Sodium exceeded calcium in percentage of total cation milliequivalents per liter in three samples collected during late summer and early autumn low flows, and calcium was the predominant cation in three samples 


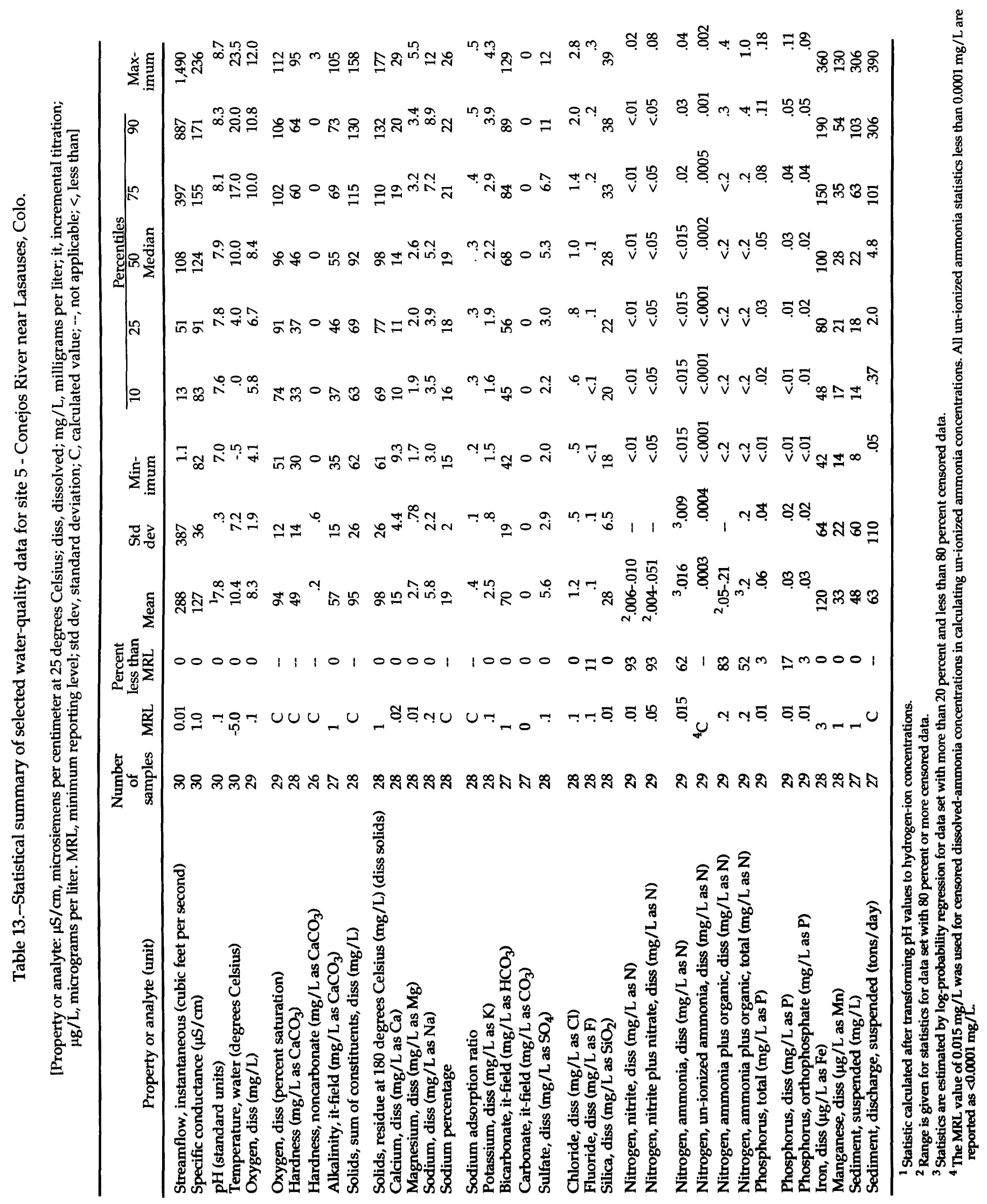


Table 14.--Regression equations for selected water-quality analytes with selected field properties and time for site 5 - Conejos River near Lasauses, Colo.

[Analyte: ${ }^{\circ} \mathrm{C}$. degrees Celsius; diss, dissolved; ortho, orthophosphate. Unit: $\mathrm{mg} / \mathrm{L}$, milligrams per liter; $\mu \mathrm{g} / \mathrm{L}$, micrograms per liter. Regression equation: q, streamflow, in cubic feet per second; qlog, base 10 logarithm of streamflow, in cubic feet per second; sc, specific conductance, in microsiemens per centimeter at $25^{\circ} \mathrm{C}$; sea ${ }^{1}$, seasonality variable; temp, water temperature, in ${ }^{\circ} \mathrm{C}$; DOlog, base 10 logarithm of dissolved-oxygen concentration, in $\mathrm{mg} / \mathrm{L}$; sclog, base 10 logarithm of specific conductance, in microsiemens per centimeter at $25^{\circ} \mathrm{C}: \mathrm{pH}$, in standard $\mathrm{pH}$ units; $\mathrm{DO}$, dissolved-oxygen concentration, in $\mathrm{mg} / \mathrm{L}$. Adj R ${ }^{2}$, adjusted coefficient of determination (Ott, 1993). Method: MLR, multiple linear regression; KTR, Kendall-Theil robust line. --, not applicable]

\begin{tabular}{|c|c|c|c|c|}
\hline Analyte & Unit & Regression equation & Adj $R^{2}$ & Method \\
\hline $\begin{array}{l}\text { Solids, residue at } 180^{\circ} \mathrm{C} \\
\text { (dissolved solids) }\end{array}$ & $\mathrm{mg} / \mathrm{L}$ & $76.1+0.029 q-19.486 q \log +0.414 \mathrm{sc}-5.186$ sea & 0.909 & MLR \\
\hline Calcium & $\mathrm{mg} / \mathrm{L}$ & $56.8-0.976 \mathrm{qlog}+0.190 \mathrm{sc}-30.669 \mathrm{sclog}-0.710 \mathrm{sea}$ & .951 & MLR \\
\hline Magnesium & $\mathrm{mg} / \mathrm{L}$ & $10^{(0.174-0.024 \mathrm{qlog}+0.002 \mathrm{sc}-0.003 \text { temp })}$ & .917 & MLR \\
\hline Sodium & $\mathrm{mg} / \mathrm{L}$ & $8.22+0.002 q-1.294 q \log +0.038 s c-5.814$ DOlog -0.665 sea & .916 & MLR \\
\hline Potassium & $\mathrm{mg} / \mathrm{L}$ & $10^{(-0.461+0.763 \text { sclog }-0.827 \text { DOlog }-0.053 \text { sea })}$ & .844 & MLR \\
\hline Bicarbonate, as $\mathrm{HCO}_{3}$ & $\mathrm{mg} / \mathrm{L}$ & $40.66+0.494 \mathrm{sc}+6.554 \mathrm{pH}+9.541 \mathrm{DO}-183.26 \mathrm{DOlog}$ & .927 & MLR \\
\hline Sulfate, as $\mathrm{SO}_{4}$ & $\mathrm{mg} / \mathrm{L}$ & $10^{(-6.460-0.082 \mathrm{q} \log -0.011 \mathrm{sc}+4.424 \mathrm{sclog}-0.052 \mathrm{DO}-0.104 \mathrm{sea})}$ & .845 & MLR \\
\hline Chloride & $\mathrm{mg} / \mathrm{L}$ & $10^{(0.614+0.003 \mathrm{sc}-0.921 \text { DOlog }-0.019 \text { temp })}$ & .610 & MLR \\
\hline Fluoride & $\mathrm{mg} / \mathrm{L}$ & $-0.056+0.0013 \mathrm{sc}$ & -- & KTR \\
\hline Silica, as $\mathrm{SiO}_{2}$ & $\mathrm{mg} / \mathrm{L}$ & $10^{(0.924-0.045 \mathrm{qlog}+0.346 \mathrm{sclog}-0.014 \mathrm{DO}-0.053 \mathrm{sea})}$ & .923 & MLR \\
\hline Phosphorus, total, as $\Gamma$ & $\mathrm{mg} / \mathrm{L}$ & $10^{(-1.459+0.0002 q+0.226 \text { sea })}$ & .644 & MLR \\
\hline Phosphorus, diss, as P & $\mathrm{mg} / \mathrm{L}$ & $0.023+0.014$ sea & -- & KTR \\
\hline $\begin{array}{l}\text { Phosphorus, ortho, } \\
\text { diss, as } \mathrm{P}\end{array}$ & $\mathrm{mg} / \mathrm{L}$ & $0.20+0.00002 q+0.018 \mathrm{DO}-0.261 \mathrm{DOlog}+0.005$ sea & .767 & MLR \\
\hline Iron, diss & $\mu \mathrm{g} / \mathrm{L}$ & $484.5+0.128 q+53.72 \mathrm{DO}-940.2$ DOlog & .775 & MLR \\
\hline Manganese, diss & $\mu \mathrm{g} / \mathrm{L}$ & $764.3+1.975 \mathrm{sc}-470.7 \mathrm{sclog}$ & .711 & MLR \\
\hline
\end{tabular}

${ }^{1}$ sea $=\sin (T)+\cos (T)$ where $T$ equals the time, in months, from December 1, 1992, times 0.5236. 
collected in the spring of 1995 . The median specificconductance value was 322 , the median $\mathrm{pH}$ value was 8.3 , and the median DO percent of saturation was 108 .

DS and most major constituents were in the middle group, calcium and magnesium were in the low group, and silica was in the high group. The DS and major-constituent concentrations at this site reflect the influence of anthropogenic sources upstream from site 4. Because concentrations in the main stem were much larger than those in the Conejos River, the Rio Grande was usually the major contributor of DS and most major constituents at site 6 even when the Conejos River was the major contributor of streamflow. From an analysis of comparative monthly samples, the instantaneous loads of DS at site 5 ranged from 1.5 to 123 percent of the instantaneous load at site 4 and were on average 15 percent. Instantaneous loads are equal to the instantaneous streamflow multiplied by the analyte concentration and are a measure of the total amount of an analyte passing the sampling site. Silica was the exception to this pattern; because silica concentrations in the main stem and Conejos River were about equal, the major source of streamflow was usually the major contributor of silica at site 6 .

DS (-0.46) and most major constituents ( -0.40 to -0.68 ) showed moderate negative correlations with streamflow. The smallest concentrations were detected during high spring flows and the largest concentrations were detected during low flow in late summer. Sulfate $(-0.27)$ and silica $(-0.21)$ showed no correlation with streamflow.

Most nutrients were in the middle group; the median concentration of $\mathrm{NO}_{2}$ and $\mathrm{NO}_{2}+\mathrm{NO}_{3}$ were below their respective MDL's. With the exception of a few samples, total nitrogen concentrations at site 6 were usually within the range of 0.4 to $0.6 \mathrm{mg} / \mathrm{L}$ as $\mathrm{N}$; the relative amounts of the different nitrogen analytes changed during the year, however. $\mathrm{NO}_{2}+\mathrm{NO}_{3}$ and dissolved-ammonia concentrations were largest during the winter months. At other times of the year, because of dilution or uptake by biota, $\mathrm{NO}_{2}+\mathrm{NO}_{3}$

concentrations were censored and dissolved-ammonia concentrations were smaller or censored.

Concentrations of dissolved ammonia plus organic nitrogen and total ammonia plus organic nitrogen were largest during the high spring flows and in the late summer and were smallest, near or below the MRL, during the winter months. For the latter two nutrients, the increase in organic nitrogen during the spring high flow and in late summer was much larger than the decrease in ammonia.

Dissolved-iron concentrations were larger than expected for well-oxygenated surface waters (Hem, 1985); dissolved iron, however, was in the middle group. Dissolved-iron concentrations showed a moderate negative correlation with streamflow $(-0.55)$, possibly due to particulates and/or colloids that passed through a 0.45 -micron filter (Kennedy and others, 1974). Dissolved manganese was in the high group even though dissolved-manganese concentrations were smaller than expected based on the dissolvedmanganese concentrations at sites 4 and 5 . The smaller dissolved-manganese concentrations probably were due to precipitation or coprecipitation of manganese in the reach upstream from site 6 . Summary statistics for field-property and chemical-analyte data for site 6 are presented in table 15. Regression equations that relate selected water-quality data to selected field properties and time are presented in table 16.

\section{Site 7 - Rio Grande below Taos Junction Bridge, near Taos, N. Mex.}

Site 7 is an integrator site on the main stem approximately $12 \mathrm{mi}$ southwest of Taos, New Mexico. The USGS streamflow-gaging station for this site is located approximately $1.7 \mathrm{mi}$ downstream from a bridge on State Highway 567. Low-flow samples were collected by wading between the bridge and the gage, and high-flow samples were collected from a cableway at the gage.

For most of the reach between sites 6 and 7, the Rio Grande flows through the Rio Grande Gorge, which is eroded into volcanic rocks in the lower San Luis Valley and Taos Plateau. From the Colorado-New Mexico State line to the NM 567 Bridge, the Rio Grande is designated a Wild and Scenic River. Major land uses in the $1,950-\mathrm{mi}^{2}$ drainage area of this reach include forest and rangeland (U.S. Geological Survey, 1986). A large molybdenum mine and tailings pond have been active along the Red River, a tributary to this reach, and active perlite quarries are on the plateau west of the river. Major surficial deposits and bedrock types in this area include Precambrian gneiss and granite; Pennsylvanian sedimentary rocks; and Quaternary lava and unconsolidated gravel, sand, and silt (Dane and Bachman, 1965; Tweto, 1979).

Streamflow at site 7 is seasonal; high flows occur in late spring and early summer. During these high flows, the increase in streamflow between sites 6 and 7 


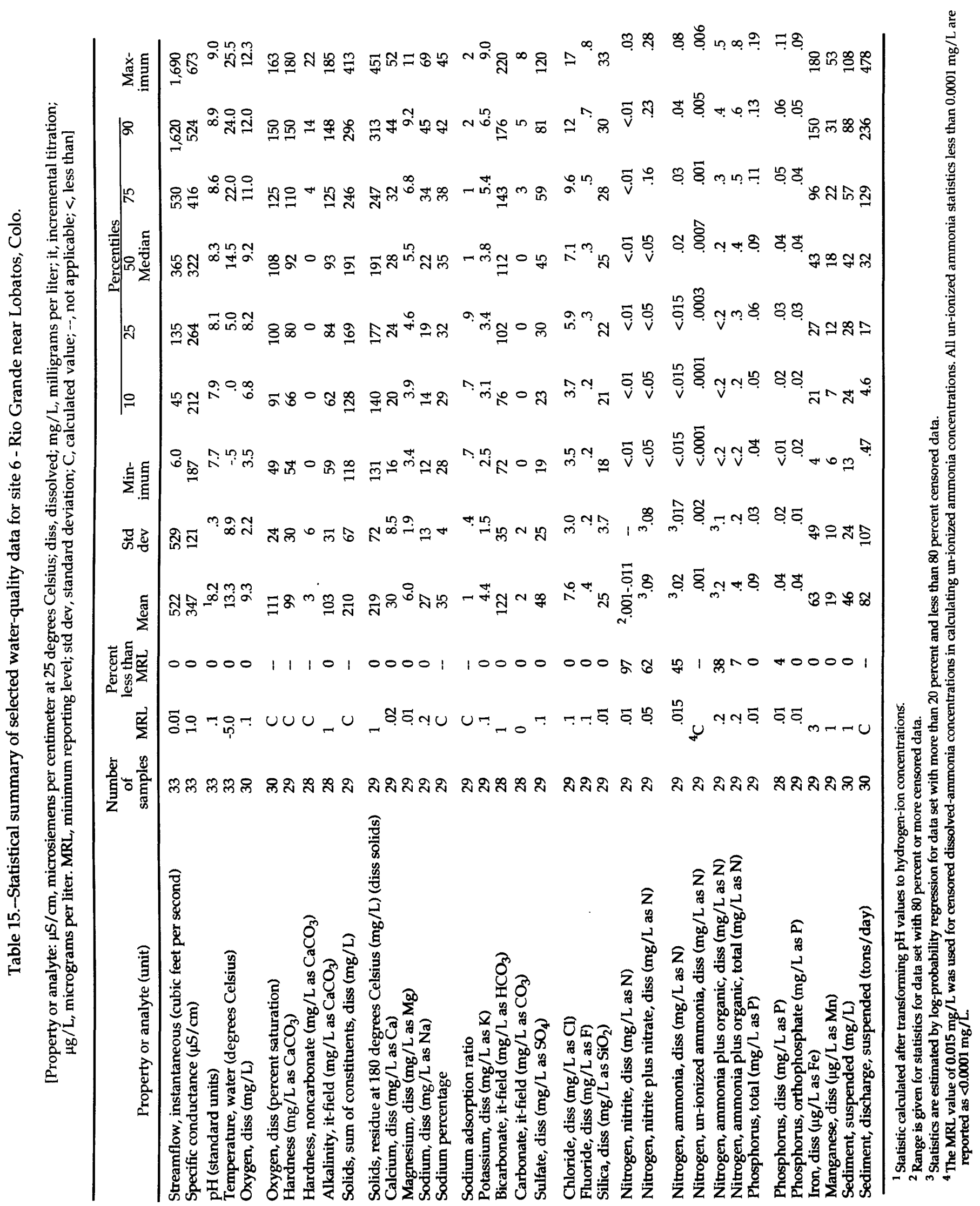


Table 16.--Regression equations for selected water-quality analytes with selected field properties and time for site 6 - Rio Grande near Lobatos, Colo.

[Analyte: ${ }^{\circ} \mathrm{C}$, degrees Celsius; amm + org, ammonia plus organic; diss, dissolved; ortho, orthophosphate. Unit: $\mathrm{mg} / \mathrm{L}$, milligrams per liter; $\mu \mathrm{g} / \mathrm{L}$, micrograms per liter. Regression equation: $\mathrm{q}$, streamflow, in cubic feet per second; sc, specific conductance, in microsiemens per centimeter at $25^{\circ} \mathrm{C}$; sclog, base 10 logarithm of specific conductance, in microsiemens per centimeter at $25^{\circ} \mathrm{C}$; sea ${ }^{\mathrm{l}}$, seasonality variable; DOlog, base 10 logarithm of dissolved-oxygen concentration, in $\mathrm{mg} / \mathrm{L}$; temp, water temperature, in ${ }^{\circ} \mathrm{C}$; $\mathrm{pH}$, in standard $\mathrm{pH}$ units; qlog, base 10 logarithm of streamflow, in cubic feet per second; $\mathrm{DO}$, dissolvedoxygen concentration, in $\mathrm{mg} / \mathrm{L}$. Adj $\mathrm{R}^{2}$, adjusted coefficient of determination (Ott, 1993). Method: MLR, multiple linear regression; KTR, Kendall-Theil robust line. --, not applicable]

\begin{tabular}{|c|c|c|c|c|}
\hline Analyte & Unit & Regression equation & Adj $R^{2}$ & Method \\
\hline $\begin{array}{l}\text { Solids, residue at } 180^{\circ} \mathrm{C} \\
\text { (dissolved solids) }\end{array}$ & $\mathrm{mg} / \mathrm{L}$ & $\begin{array}{l}10^{(0.640+0.00003 q+0.0005 s c+0.568 s c l o g}+0.021 p H \\
\quad-0.085 \text { DOlog }-0.019 \text { sea })\end{array}$ & 0981 & MLR \\
\hline Calcium & $\mathrm{mg} / \mathrm{L}$ & $\begin{array}{c}-67.70+0.040 \mathrm{sc}=20.886 \mathrm{sclog}+1.918 \mathrm{pH}+17.164 \text { DOlog } \\
+0.123 \text { temp) }\end{array}$ & .954 & MLR \\
\hline Magnesium & $\mathrm{mg} / \mathrm{L}$ & $\begin{array}{r}-21.67+0.008 \mathrm{sc}+7.138 \mathrm{sclog}+0.513 \mathrm{pH} \\
+3.169 \mathrm{DOlog}+0.360 \mathrm{sea}\end{array}$ & .957 & MLR \\
\hline Sodium & $\mathrm{mg} / \mathrm{L}$ & $81.51-2.308 \mathrm{qlog}+0.153 \mathrm{sc}-35.106 \mathrm{sclog}-2.219 \mathrm{pH}$ & .978 & MLR \\
\hline Potassium & $\mathrm{mg} / \mathrm{L}$ & $-6.78+0.013 \mathrm{sc}-0.931 \mathrm{DO}+16.385 \mathrm{DOlog}-0.260$ sea & .918 & MLR \\
\hline Bicarbonate, as $\mathrm{HCO}_{3}$ & $\mathrm{mg} / \mathrm{L}$ & $10^{(1.121-0.048 \mathrm{q} \log +0.006 \mathrm{sc}+0.400 \mathrm{sclog}-0.007 \mathrm{DO}-0.005 \text { temp })}$ & .947 & MLR \\
\hline Sulfate, as $\mathrm{SO}_{4}$ & $\mathrm{mg} / \mathrm{L}$ & $-51.96+10.29 q \log +0.205 \mathrm{sc}+0.495$ temp & .946 & MLR \\
\hline Chloride & $\mathrm{mg} / \mathrm{L}$ & $-1.356+0.030 \mathrm{sc}-0.085$ temp & .968 & MLR \\
\hline Fluoride & $\mathrm{mg} / \mathrm{L}$ & $10^{(-2.578-0.00009 q+0.881 \mathrm{sclog})}$ & .829 & MLR \\
\hline Silica, as $\mathrm{SiO}_{2}$ & $\mathrm{mg} / \mathrm{L}$ & $10^{(1.185+0.218 \text { DOlog - } 0.040 \text { sea })}$ & .753 & MLR \\
\hline $\begin{array}{l}\text { Nitrogen, amm + org, } \\
\text { total, as } \mathrm{N}\end{array}$ & $\mathrm{mg} / \mathrm{L}$ & $0.267+0.011$ temp & -- & KTR \\
\hline Phosphorus, total, as $\mathrm{P}$ & $\mathrm{mg} / \mathrm{L}$ & $1.941+0.001 \mathrm{sc}-0.848 \mathrm{sclog}-0.007 \mathrm{DO}$ & .467 & MLR \\
\hline $\begin{array}{l}\text { Phosphorus, diss, as } \mathrm{P} \\
\text { Phosphorus, ortho, }\end{array}$ & $\mathrm{mg} / \mathrm{L}$ & $0.202+0.012 \mathrm{qlog}+0.0001 \mathrm{sc}-0.021 \mathrm{pH}-0.005 \mathrm{DO}$ & .452 & MLR \\
\hline diss, as $P$ & $\mathrm{mg} / \mathrm{L}$ & $0.413+0.015 \mathrm{glog}+0.0003 \mathrm{sc}-0.212 \mathrm{sclog}$ & .558 & MLR \\
\hline Iron, diss & $\mu \mathrm{g} / \mathrm{L}$ & $-163.48+0.064 q-86.971 \mathrm{sclog}-38.287 \mathrm{DO}+796.81 \mathrm{DOlog}$ & .700 & MLR \\
\hline Manganese, diss & $\mu \mathrm{g} / \mathrm{L}$ & $10^{(1.210+0.097 \text { sea })}$ & .154 & MLR \\
\hline
\end{tabular}

${ }^{1}$ sea $=\sin (T)+\cos (T)$ where $T$ equals the time, in months, from December 1, 1992, times 0.5236. 
is due mainly to inputs from tributaries along the east side of the Rio Grande. During low flow, the increase in streamflow due to ground-water inflow may equal or exceed that from the tributaries (Winograd, 1959). The annual mean discharge at this site for WY 1926 to 1995 was $767 \mathrm{ft}^{3} / \mathrm{s}$ (Ortiz and Lange, 1996). The annual mean discharge for WY's 1993 was $950 \mathrm{ft}^{3} / \mathrm{s}$ (Cruz and others, 1994); for WY 1994 was $887 \mathrm{ft}^{3} / \mathrm{s}$ (Borland and Ong, 1995); and for WY 1995 was 1,186 $\mathrm{ft}^{3} / \mathrm{s}$ (Ortiz and Lange, 1996).

The water sampled at site 7 was a welloxygenated type whose chemical composition varied from calcium bicarbonate to calcium sodium bicarbonate. The calcium sodium bicarbonate type was detected mainly during low flow in late summer. The median specific-conductance value was 297 , the median $\mathrm{pH}$ value was 8.3 , and the median DO percent of saturation was 102. DS and the major constituents were in the middle group. For most major constituents, the median concentrations were about equal to or smaller than comparative concentrations at site 6 . Streamflow had a moderate to strong negative correlation with specific conductance (-0.59), DS $(-0.64)$, and most major constituents $(-0.38$ to -0.86$)$ except potassium $(-0.16)$, which showed no correlation to streamflow.

Most nutrients were in the middle group; dissolved phosphorus was in the low group. The median concentrations of $\mathrm{NO}_{2}$ and dissolved ammonia plus organic nitrogen were below their respective MDL's. Most median nutrient concentrations stayed unchanged or decreased between sites 6 and 7, and these nutrients $(0.05$ to 0.60$)$ showed no correlation to moderate positive correlation with streamflow. $\mathrm{NO}_{2}+$ $\mathrm{NO}_{3}$ concentrations, however, increased significantly, at a 95-percent confidence level, between the sites and showed no correlation with streamflow $(-0.27)$. The increase in $\mathrm{NO}_{2}+\mathrm{NO}_{3}$ concentrations probably were due to a combination of mineralization/nitrification of organic nitrogen in the main stem, the inflow of ground water with a larger $\mathrm{NO}_{2}+\mathrm{NO}_{3}$ concentration to the main stem and tributaries, and irrigation-return flow and WWTP discharges to tributaries.

Dissolved iron and dissolved manganese were in the middle group. Dissolved iron (0.86) showed a strong positive correlation with streamflow, whereas dissolved manganese $(-0.01)$ showed no correlation with streamflow. Summary statistics for the fieldproperty and chemical-analyte data for site 7 are presented in table 17. Regression equations that relate selected water-quality data to selected field properties and time are presented in table 18.

\section{Site 8 - Rio Chama near Chamita, N. Mex.}

Site 8 is an integrator site on the largest tributary to the Rio Grande in the study unit. The USGS streamflow-gaging station for this site is located downstream from the bridge on U.S. Highway 285 approximately $0.5 \mathrm{mi}$ west of Chamita, New Mexico. Low-flow samples were collected by wading upstream from the bridge, and high-flow samples were collected from a cableway about $300 \mathrm{ft}$ downstream from the gage. On September 1, 1994, high water scoured the channel and caused major changes in the cross section.

The 3,040- $\mathrm{mi}^{2}$ contributing drainage basin for site 8 includes the Chama Basin, the southern San Juan Mountains, and the northern part of the Jemez Mountains. The major land use is forest; rangeland is a distant second use (U.S. Geological Survey, 1986). Some agricultural land is present in lowland areas along the river. Major bedrock types include Precambrian metamorphic rock; Cretaceous sedimentary rock; and Tertiary tuff, lava, and sedimentary rock (Dane and Bachman, 1965; Tweto, 1979).

Streamflow at site 8 is seasonal but regulated by upstream flood-control reservoirs. High flows are in the late spring and early summer and there may be no flow at certain times during some years (Borland and Ong, 1995). Streamflow is affected by transmountain diversions from the San Juan River Basin through the Azotea tunnel and diversions for irrigation. The annual mean discharge at site 8 for WY's 1971 to 1995 was $611 \mathrm{ft}^{3} / \mathrm{s}$ (Ortiz and Lange, 1996). The annual mean discharge for WY 1993 was $819 \mathrm{ft}^{3} / \mathrm{s}$ (Cruz and others, 1994); for WY 1994 was $862 \mathrm{ft}^{3} / \mathrm{s}$ (Borland and Ong, 1995); and for WY 1995 was $881 \mathrm{ft}^{3} / \mathrm{s}$ (Ortiz and Lange, 1996).

The water sampled at site 8 for the most part was a well-oxygenated, calcium bicarbonate type. The median specific-conductance value was 288 , the median $\mathrm{pH}$ value was 8.2 , and the median DO percent of saturation was 101. DS and most major constituents were in the middle group; chloride, fluoride, potassium, and silica were in the low group. The median concentrations of most nutrients were below their respective MDL's. Dissolved ammonia and total ammonia plus organic nitrogen were in the middle group; total phosphorus and dissolved phosphorus were in the low group. Dissolved iron was in the high 


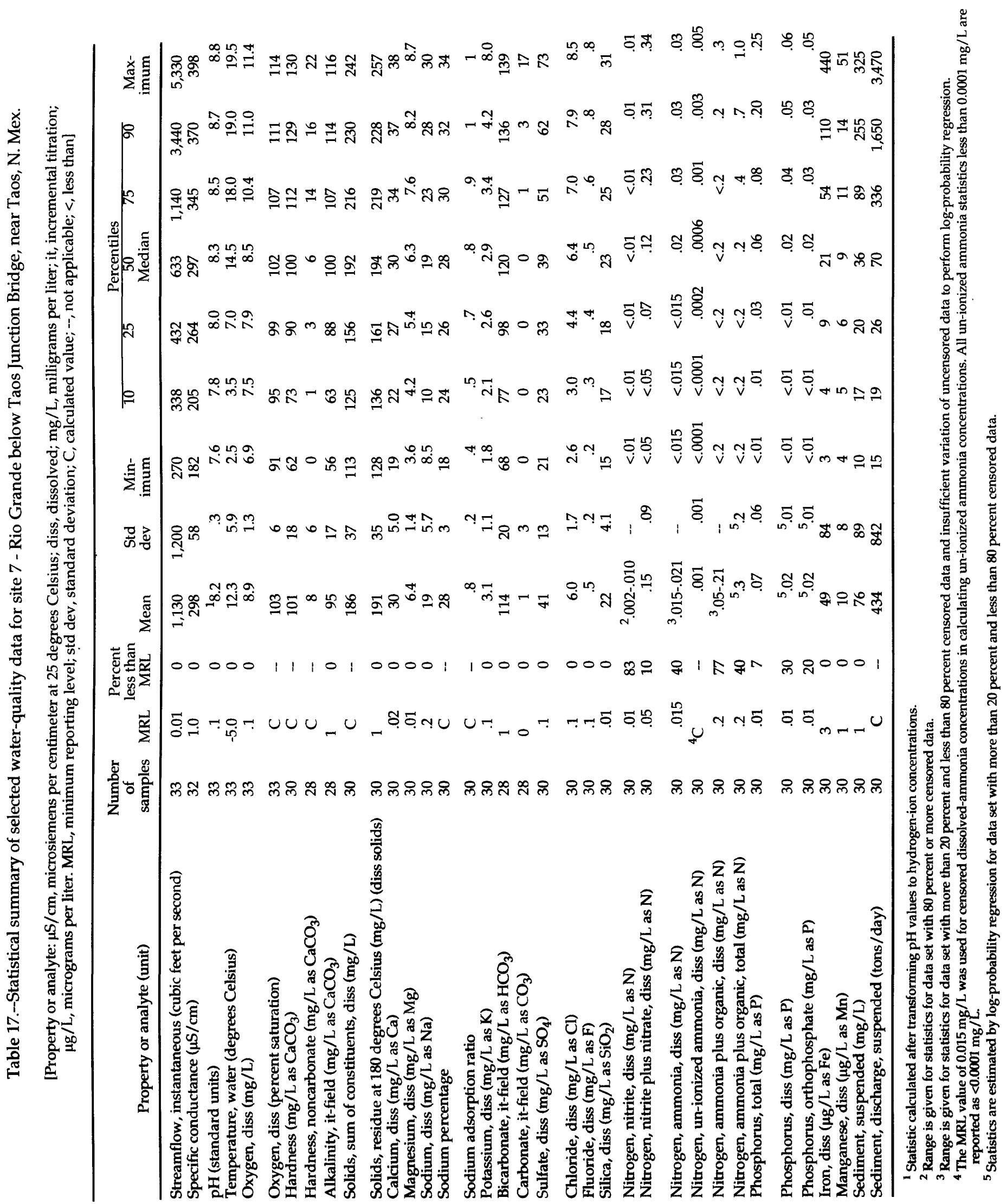


Table 18.--Regression equations for selected water-quality analytes with selected field properties and time for site 7 - Rio Grande below Taos Junction Bridge, near Taos, N. Mex.

[Analyte: ${ }^{\circ} \mathrm{C}$, degrees Celsius; $\mathrm{NO}_{2}+\mathrm{NO}_{3}$, nitrite plus nitrate; diss, dissolved; ortho, orthophosphate. Unit: $\mathrm{mg} / \mathrm{L}$, milligrams per liter; $\mu \mathrm{g} / \mathrm{L}$, micrograms per liter. Regression equation: $s c l o g$, base 10 logarithm of specific conductance, in microsiemens per centimeter at $25^{\circ} \mathrm{C}$; qlog, base 10 logarithm of streamflow, in cubic feet per second; sc, specific conductance, in microsiemens per centimeter at $25^{\circ} \mathrm{C}$; temp, water temperature, in ${ }^{\circ} \mathrm{C} ; \mathrm{q}$, streamflow, in cubic feet per second; sea ${ }^{1}$, seasonality variable; DOlog, base 10 logarithm of dissolved-oxygen concentration, in $\mathrm{mg} / \mathrm{L} ; \mathrm{pH}$, in standard $\mathrm{pH}$ units. Adj $\mathrm{R}^{2}$, adjusted coefficient of determination (Ott, 1993). Method: MLR, multiple linear regression; KTR, Kendall-Theil robust line. --, not applicable]

\begin{tabular}{|c|c|c|c|c|}
\hline Analyte & Unit & Regression equation & Adj $R^{2}$ & Method \\
\hline $\begin{array}{l}\text { Solids, residue at } 180^{\circ} \mathrm{C} \\
\text { (dissolved solids) }\end{array}$ & $\mathrm{mg} / \mathrm{L}$ & $10^{(23.748+0.572 \mathrm{sc})}$ & 0.954 & MLR \\
\hline Calcium & $\mathrm{mg} / \mathrm{L}$ & $10^{(-2.170-0.0014 \mathrm{sc}+1.644 \mathrm{sclog})}$ & .940 & MLR \\
\hline Magnesium & $\mathrm{mg} / \mathrm{L}$ & $10^{(-0.715-0.094 \mathrm{qlog}+0.717 \text { sclog }+0.002 \text { temp })}$ & .957 & MLR \\
\hline Sodium & $\mathrm{mg} / \mathrm{L}$ & $10^{(-3.193+0.00002 q+1.815 \text { sclog }-0.003 \text { temp })}$ & .951 & MLR \\
\hline Potassium & $\mathrm{mg} / \mathrm{L}$ & $10^{(12.877+0.010 \mathrm{sc}-6.255 \mathrm{sclog})}$ & .247 & MLR \\
\hline Bicarbonate, as $\mathrm{HCO}_{3}$ & $\mathrm{mg} / \mathrm{L}$ & $10^{(0.709-0.064 \mathrm{qlog}+0.619 \mathrm{sclog}-0.018 \mathrm{sea})}$ & .949 & MLR \\
\hline Sulfate, as $\mathrm{SO}_{4}$ & $\mathrm{mg} / \mathrm{L}$ & $10^{(-9.024+0.00005 q-0.005 s c+4.973 \text { sclog }-0.328 \text { DOlog }+0.019 \text { sea })}$ & .960 & MLR \\
\hline Chloride & $\mathrm{mg} / \mathrm{L}$ & $10^{(-3.610+1.519 \mathrm{sclog}+0.661 \mathrm{DOlog})}$ & .950 & MLR \\
\hline Fluoride & $\mathrm{mg} / \mathrm{L}$ & $10^{(1.409-0.434 q \log -0.495 \text { DOlog })}$ & .897 & MLR \\
\hline Silica, as $\mathrm{SiO}_{2}$ & $\mathrm{mg} / \mathrm{L}$ & $10^{(9.59+0.0001 q-0.272 q \log -0.008 s c+5.728 s c l o g-0.097 \text { temp })}$ & .778 & MLR \\
\hline $\begin{array}{l}\text { Nitrogen, } \mathrm{NO}_{2}+\mathrm{NO}_{3} \\
\text { diss, as } \mathrm{N}\end{array}$ & $\mathrm{mg} / \mathrm{L}$ & $0.162-0.74$ sea & -- & KTR \\
\hline $\begin{array}{l}\text { Phosphorus, total, as } \mathrm{P} \\
\text { Phosphorus, ortho, }\end{array}$ & $\mathrm{mg} / \mathrm{L}$ & $-0.221+0.098$ qlog & - & KTR \\
\hline diss, as $\mathrm{P}$ & $\mathrm{mg} / \mathrm{L}$ & $-0.033+0.019 \mathrm{qlog}$ & -- & KTR \\
\hline Iron, diss & $\mu \mathrm{g} / \mathrm{L}$ & $10^{(4.192+0.913 \mathrm{qlog}-0.670 \mathrm{pH})}$ & .677 & MLR \\
\hline Manganese, diss & $\mu \mathrm{g} / \mathrm{L}$ & $1,214.3-0.009 q+0.703 s c-569.34$ sclog & .161 & MLR \\
\hline
\end{tabular}

${ }^{1}$ sea $=\sin (T)+\cos (T)$ where $T$ equals the time, in months, from December 1, 1992, times 0.5236 . 
group; dissolved-iron concentrations were larger than expected for well-oxygenated surface waters (Hem, 1985), possibly due to particulates and/or colloids that passed through a 0.45 -micron filter (Kennedy and others, 1974). Dissolved manganese was in the middle group. Summary statistics for field-property and chemical-analyte data for site 8 are presented in table 19.

Streamflow showed moderate negative correlations with specific conductance $(-0.44)$, DS $(-0.47)$, most major constituents $(-0.34$ to -0.56$)$, and dissolved manganese $(-0.42)$ and moderate positive correlations with total ammonia plus organic nitrogen $(0.31)$ and dissolved iron (0.45). Potassium (0.21) and most nutrients ( 0 to 0.28 ) showed no correlation to streamflow. Regression equations that relate selected water-quality data to selected field properties and time are presented in table 20 .

\section{Site 9 - Rio Grande at Otowi Bridge, near San Ildefonso, N. Mex.}

Site 9 is an integrator site on the main stem approximately $1.8 \mathrm{mi}$ southwest of San Ildefonso, New Mexico. The USGS streamflow-gaging station for this site is located on a former railroad bridge about $400 \mathrm{ft}$ downstream from State Highway 502. Low-flow samples were collected by wading near the gage, and high-flow samples were collected from a cableway about $100 \mathrm{ft}$ upstream from the gage.

The contributing drainage area for the reach between sites 7 and 9 is $4,400 \mathrm{mi}^{2}$; approximately 69 percent of the area is in the Rio Chama drainage basin. Major land uses in this area, excluding the Rio Chama drainage basin, are forest and rangeland (U.S.

Geological Survey, 1986). Downstream from site 7, the Rio Grande Gorge gradually widens, and land along the main stem and tributaries is used for farming and orchards. Española, New Mexico, is located along the Rio Grande about 10 mi upstream from site 9. Major surficial deposits and bedrock types, excluding the Rio Chama drainage basin, are Precambrian gneiss and granite and Quaternary lava and unconsolidated gravel, sand, and silt (Dane and Bachman, 1965).

Streamflow at site 9 is seasonal; high flows occur in late spring and early summer. High flows at this site may result from high flows on the main stem Rio Grande, on the Rio Chama, or may be the summation of smaller flows on both. During the high-intensity sampling phase, streamflow at site 9 was the summation of flow at sites 7 and 8; the high spring flow at site 7 , however, occurred from 1 to 6 weeks later than the high flow at site 8 . The annual mean discharge at site 9 for WY's 1910 to 1995 was $1,600 \mathrm{ft}^{3} / \mathrm{s}$ (Ortiz and Lange, 1996). The annual mean discharge for WY 1993 was $1,950 \mathrm{ft}^{3} / \mathrm{s}$ (Cruz and others, 1994); for WY 1994 was $1,902 \mathrm{ft}^{3} / \mathrm{s}$ (Borland and Ong, 1995); and for WY 1995 was $2,234 \mathrm{ft}^{3} / \mathrm{s}$ (Ortiz and Lange, 1996).

The water sampled at site 9 for the most part was a well-oxygenated, calcium bicarbonate type. The median specific-conductance value was 307 , the median $\mathrm{pH}$ value was 8.1 , and the median DO percent of saturation was 95. DS and the major constituents were in the middle group. Because the DS and majorconstituent concentrations in the main stem (site 7) and the Rio Chama (site 8 ) were about the same, the river with the higher streamflow was usually the major contributor to the DS and major-constituent loads at site 9. Streamflow showed moderate negative correlations with specific conductance $(-0.49)$, DS $(-0.40)$, and most major constituents $(-0.32$ to -0.62$)$. Potassium (-0.19) showed no correlation with streamflow.

$\mathrm{NO}_{2}+\mathrm{NO}_{3}$, dissolved ammonia, and total phosphorus were in the low group; dissolved phosphorus and orthophosphate were in the middle group. The median concentrations of $\mathrm{NO}_{2}$ and dissolved ammonia plus organic nitrogen were below their respective MDL's. Most nutrients (0.39 to 0.51) showed a moderate positive correlation to streamflow, whereas $\mathrm{NO}_{2}, \mathrm{NO}_{2}+\mathrm{NO}_{3}$, and total phosphorus showed no correlation to streamflow. Dissolved-iron and dissolved-manganese concentrations were in the middle group. Dissolved-iron concentrations, however, were larger than expected for well-oxygenated surface waters (Hem, 1985), possibly due to particulates and/or colloids that passed through a 0.45 -micron filter (Kennedy and others, 1974). Summary statistics for field-property and chemical-analyte data for site 9 are presented in table 21 . Regression equations that relate selected water-quality data to selected field properties and time are presented in table 22.

\section{Site 10 - Rito de los Frijoles in Bandelier National Monument, N. Mex.}

Site 10 is an indicator site for a small forested basin on a tributary stream draining an $18-\mathrm{mi}^{2}$ basin on the east slope of the Jemez Mountains. The streamflowgaging station for this site is located in Bandelier National Monument about $800 \mathrm{ft}$ downstream from the monument headquarters. During the high-intensity sampling phase, the gage was operated by the USGS; 


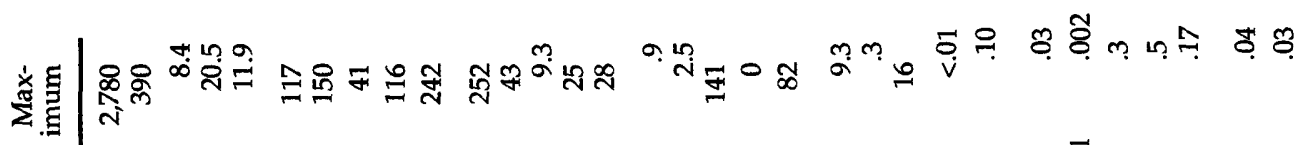

宽宽

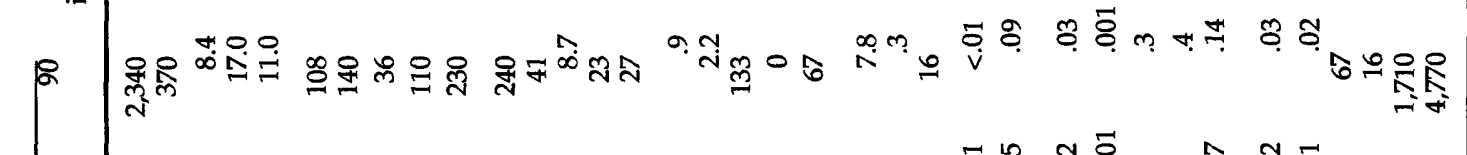

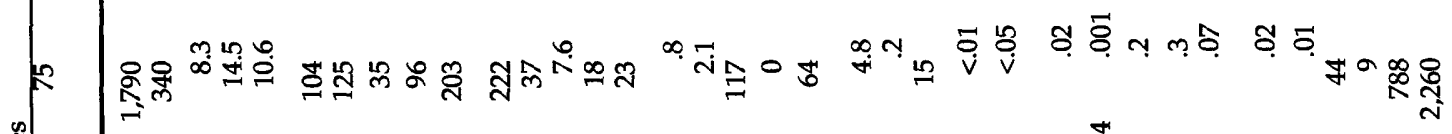

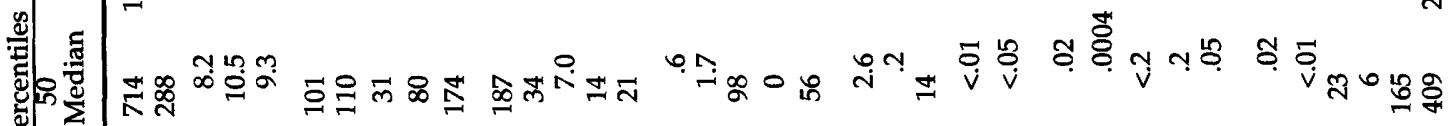
$2^{2}$

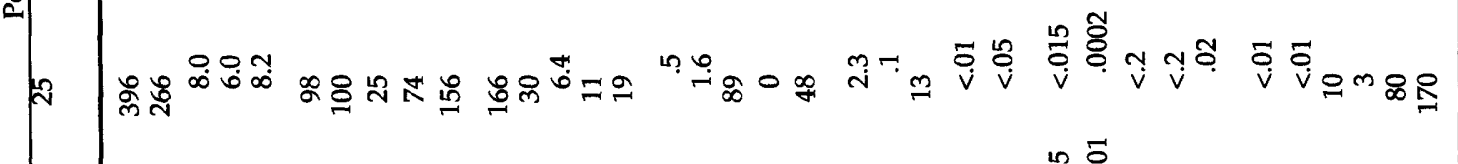

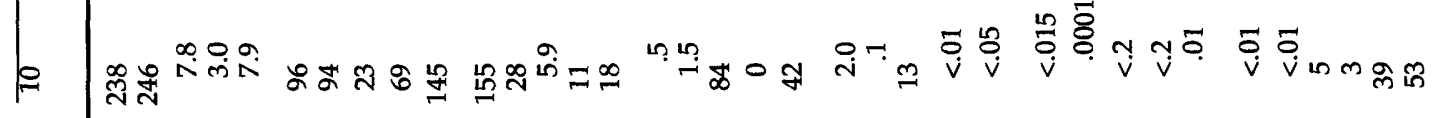
直声

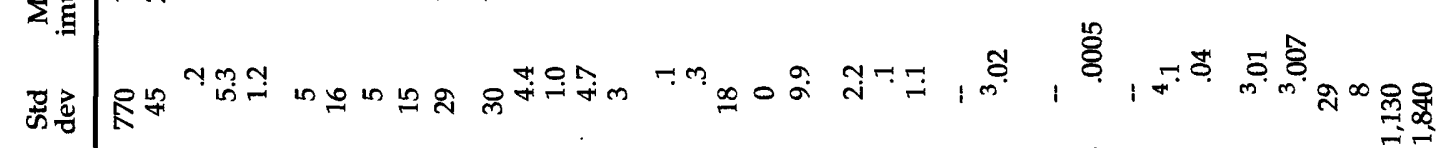
ร

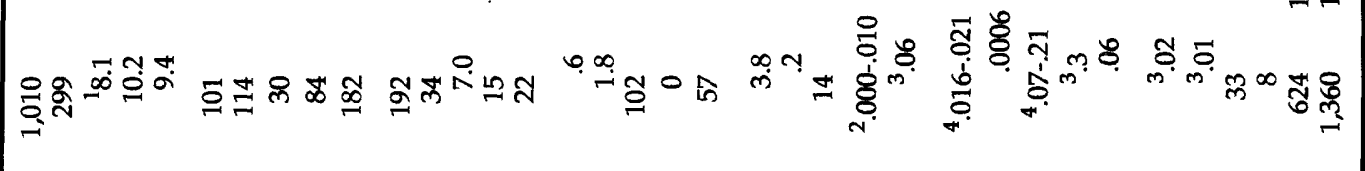

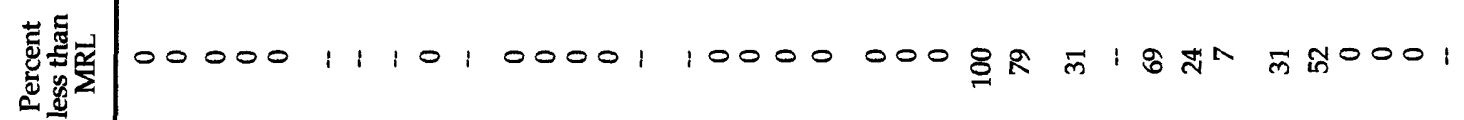

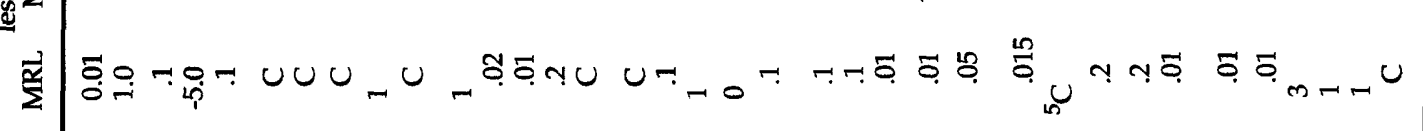

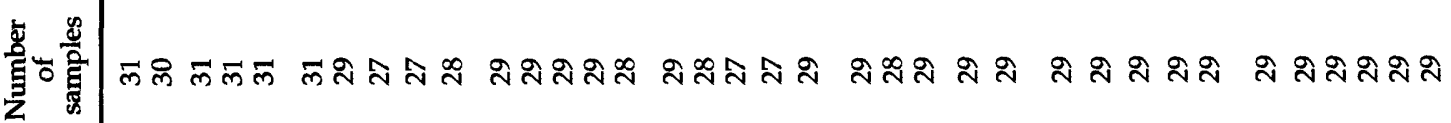

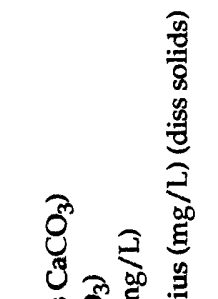
क्ष

产 
Table 20.--Regression equations for selected water-quality analytes with selected field properties and time for site 8 - Rio Chama near Chamita, N. Mex.

[Analyte: ${ }^{\circ} \mathrm{C}$, degrees Celsius; diss, dissolved. Unit: $\mathrm{mg} / \mathrm{L}$, milligrams per liter; $\mu \mathrm{g} / \mathrm{L}$, micrograms per liter. Regression equation: q, streamflow, in cubic feet per second; sc, specific conductance, in microsiemens per centimeter at $25^{\circ} \mathrm{C}$; temp, water temperature, in ${ }^{\circ} \mathrm{C}$; sea ${ }^{1}$, seasonality variable; sclog, base 10 logarithm of specific conductance, in microsiemens per centimeter at $25^{\circ} \mathrm{C} ; \mathrm{qlog}$, base 10 logarithm of streamflow, in cubic feet per second; $\mathrm{pH}$, in standard $\mathrm{pH}$ units; DOlog, base 10 logarithm of dissolved-oxygen concentration, in mg/L. Adj $\mathrm{R}^{2}$, adjusted coefficient of determination (Ott, 1993). Method: MLR, multiple linear regression; KTR, Kendall-Theil robust line. --, not applicable]

\begin{tabular}{|c|c|c|c|c|}
\hline Analyte & Unit & Regression equation & Adj $R^{2}$ & Method \\
\hline $\begin{array}{l}\text { Solids, residue at } 180^{\circ} \mathrm{C} \\
\text { (dissolved solids) }\end{array}$ & $\mathrm{mg} / \mathrm{L}$ & $-23.61+0.009 q+0.671 s c+0.726$ temp -6.950 sea & 0.949 & MLR \\
\hline Calcium & $\mathrm{mg} / \mathrm{L}$ & $10^{(-0.284+0.726 \text { sclog }+0.002 \text { temp }-0.015 \text { sea })}$ & .888 & MLR \\
\hline Magnesium & $\mathrm{mg} / \mathrm{L}$ & $-29.48+0.0008 q-1.339 q \log +14.078 \operatorname{sclog}+0.687 p H$ & .859 & MLR \\
\hline Sodium & $\mathrm{mg} / \mathrm{L}$ & $279.62+0.288 \mathrm{sc}-141 \mathrm{sclog}-0.762 \mathrm{sea}$ & .968 & MLR \\
\hline Potassium & $\mathrm{mg} / \mathrm{L}$ & $0.287+0.005 \mathrm{sc}$ & .577 & MLR \\
\hline Bicarbonate, as $\mathrm{HCO}_{3}$ & $\mathrm{mg} / \mathrm{L}$ & $10^{(0.710-0.076 \mathrm{qlog}+0.620 \mathrm{sclog}-0.002 \text { temp })}$ & .923 & MLR \\
\hline Sulfate, as $\mathrm{SO}_{4}$ & $\mathrm{mg} / \mathrm{L}$ & $10^{(-8.55+0.087 \mathrm{q} \log -0.004 \mathrm{sc}+4.435 \mathrm{sclog})}$ & .899 & MLR \\
\hline Chloride & $\mathrm{mg} / \mathrm{L}$ & $\begin{array}{r}212.6-1.485 \mathrm{q} \log +0.173 \mathrm{sc}-100.48 \mathrm{sclog}-0.868 \mathrm{pH} \\
-0.080 \text { temp }\end{array}$ & .937 & MLR \\
\hline Fluoride & $\mathrm{mg} / \mathrm{L}$ & $-0.203+0.001 s c$ & .703 & MLR \\
\hline Silica, as $\mathrm{SiO}_{2}$ & $\mathrm{mg} / \mathrm{L}$ & $108.9+0.086 \mathrm{sc}-50.720 \mathrm{sclog}+4.847$ DOlog & .661 & MLR \\
\hline Phosphorus, total, as $\mathrm{P}$ & $\mathrm{mg} / \mathrm{L}$ & $10^{(1.69-3.078 \mathrm{DOlog})}$ & -- & KTR \\
\hline Iron, diss & $\mu \mathrm{g} / \mathrm{L}$ & $10^{(6.352+0.0003 \mathrm{q}-0.649 \mathrm{pH})}$ & .468 & MLR \\
\hline Manganese, diss & $\mu \mathrm{g} / \mathrm{L}$ & $10^{(1.257-0.422 \mathrm{qlog}+0.080 \mathrm{DO})}$ & .370 & MLR \\
\hline
\end{tabular}

${ }^{1}$ sea $=\sin (T)+\cos (T)$ where $T$ equals the time, in months, from December 1, 1992, times 0.5236. 


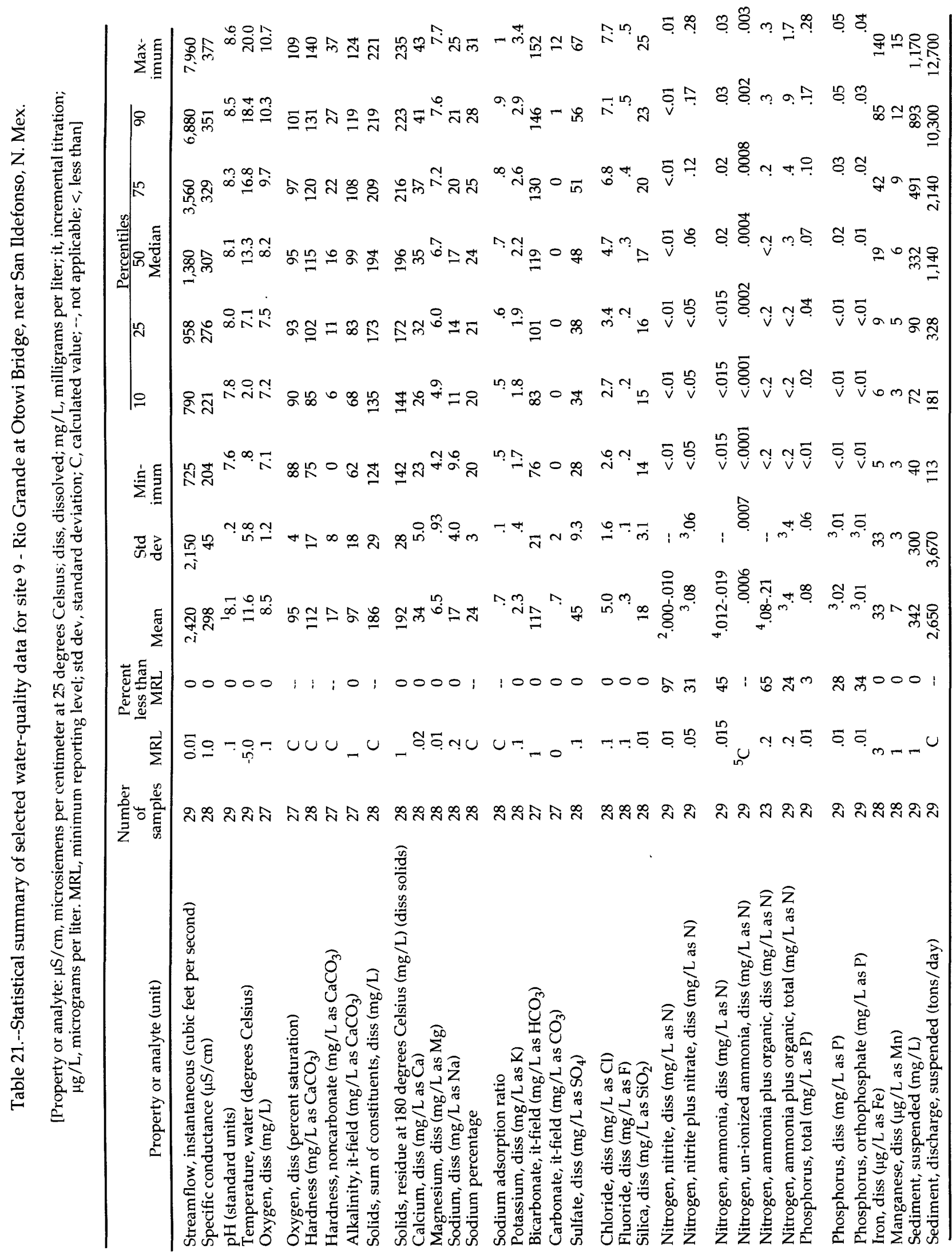

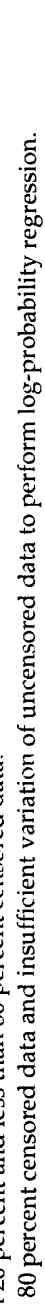
हैं ํㅝㄹ ह 究

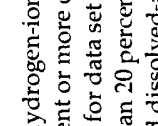
릉 흔

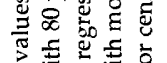

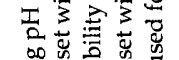

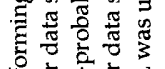
ذ

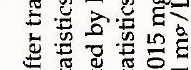

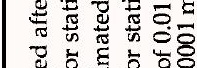
W m . 
Table 22.--Regression equations for selected water-quality analytes with selected field properties and time for site 9 - Rio Grande at Otowi Bridge, near San Ildefonso, N. Mex.

[Analyte: ${ }^{\circ} \mathrm{C}$, degrees Celsius; diss, dissolved. Unit: $\mathrm{mg} / \mathrm{L}$, milligrams per liter; $\mu \mathrm{g} / \mathrm{L}$, micrograms per liter. Regression equation: sc, specific conductance, in microsiemens per centimeter at $25^{\circ} \mathrm{C}$; DOlog, base 10 logarithm of dissolved-oxygen concentration, in $\mathrm{mg} / \mathrm{L}$; qlog, base 10 logarithm of streamflow, in cubic feet per second; sclog, base 10 logarithm of specific conductance, in microsiemens per centimeter at $25^{\circ} \mathrm{C} ; \mathrm{pH}$, in standard $\mathrm{pH}$ units; temp, water temperature, in ${ }^{\circ} \mathrm{C}$; sea ${ }^{1}$, seasonality variable; $\mathrm{q}$, streamflow, in cubic feet per second; DO, dissolved-oxygen concentration, in $\mathrm{mg} / \mathrm{L}$. Adj $\mathrm{R}^{2}$, adjusted coefficient of determination

(Ott, 1993). Method: MLR, multiple linear regression]

\begin{tabular}{|c|c|c|c|c|}
\hline Analyte & Unit & Regression equation & Adj $R^{2}$ & Method \\
\hline $\begin{array}{l}\text { Solids, residue at } 180^{\circ} \mathrm{C} \\
\text { (dissolved solids) }\end{array}$ & $\mathrm{mg} / \mathrm{L}$ & $28.61+0.545 \mathrm{sc}-11.16 \mathrm{pH}+100.18$ DOlog & 0.940 & MLR \\
\hline Calcium & $\mathrm{mg} / \mathrm{L}$ & $10^{(-0.413-0.053 \mathrm{qlog}+0.683 \mathrm{sclog}+0.052 \mathrm{pH})}$ & .891 & MLR \\
\hline Magnesium & $\mathrm{mg} / \mathrm{L}$ & $10^{(-1.990+0.892 \mathrm{sclog}+0.073 \mathrm{pH})}$ & .901 & MLR \\
\hline Sodium & $\mathrm{mg} / \mathrm{L}$ & $10^{(1.343+0.002 \mathrm{sc}-0.761 \text { DOlog }-0.010 \text { temp })}$ & .910 & MLR \\
\hline Potassium & $\mathrm{mg} / \mathrm{L}$ & $6.532+1.025 \mathrm{qlog}+0.011 \mathrm{sc}-10.275$ DOlog -0.102 temp & .275 & MLR \\
\hline Bicarbonate, as $\mathrm{HCO}_{3}$ & $\mathrm{mg} / \mathrm{L}$ & $10^{(2.042-0.085 \mathrm{q} \log +0.001 \mathrm{sc}-0.024 \mathrm{sea})}$ & .941 & MLR \\
\hline Sulfate, as $\mathrm{SO}_{4}$ & $\mathrm{mg} / \mathrm{L}$ & $10^{(-14.77+0.00003 q-0.009 s c+7.695 \text { sclog }+0.042 \text { sea })}$ & .753 & MLR \\
\hline Chloride & $\mathrm{mg} / \mathrm{L}$ & $10^{(0.627+0.003 \mathrm{sc}-0.060 \mathrm{DO}-0.021 \text { temp })}$ & .828 & MLR \\
\hline Fluoride & $\mathrm{mg} / \mathrm{L}$ & $10^{(1.979-0.302 \mathrm{qlog}-0.186 \mathrm{pH}-0.049 \text { sea })}$ & .680 & MLR \\
\hline Silica, as $\mathrm{SiO}_{2}$ & $\mathrm{mg} / \mathrm{L}$ & $10^{(4.332+0.0005 \mathrm{sc}+0.215 \mathrm{DO}-5.252 \mathrm{DOlog}-0.017 \text { temp })}$ & .676 & MLR \\
\hline $\begin{array}{l}\text { Phosphorus, total, as } \mathrm{P} \\
\text { Iron, diss }\end{array}$ & $\begin{array}{l}\mathrm{mg} / \mathrm{L} \\
\mu \mathrm{g} / \mathrm{L}\end{array}$ & $\begin{array}{l}1.06-0.0006 \mathrm{sc}-0.010 \mathrm{pH} \\
1.66+0.014 \mathrm{q}\end{array}$ & $\begin{array}{l}.270 \\
.627\end{array}$ & $\begin{array}{l}\text { MLR } \\
\text { MLR }\end{array}$ \\
\hline Manganese, diss & $\mu \mathrm{g} / \mathrm{L}$ & $10^{(6.16-0.985 \mathrm{sclog}-0.334 \mathrm{pH}-0.018 \text { temp })}$ & .409 & MLR \\
\hline
\end{tabular}

${ }^{1}$ sea $=\sin (T)+\cos (T)$ where $T$ equals the time, in months, from December 1,1992 , times 0.5236. 
for most of the period between 1983 and 1993 , however, the gage was operated by the NPS. All samples were collected by wading near the gage.

The basin drained by the Rito de los Frijoles is mainly forested (U.S. Geological Survey, 1986), and Tertiary tuff is the major rock type (Dane and Bachman, 1965). The parking area and picnic grounds for the monument's visitor center are located upstream from the gage.

Streamflow at site 10 is seasonal; high flows usually result from snowmelt in late spring or early summer. However, storms throughout the year may produce flows greater than those produced by snowmelt. Gaging streamflow at this site started in 1963; because of discontinuous records and the effects of the La Mesa forest fire in mid-June 1977 on runoff from the basin, however, the base period used for this site was 1983 to 1995 . The annual mean discharge at site 10 for WY's 1983 to 1995 was $2.22 \mathrm{ft}^{3} / \mathrm{s}$ (Ortiz and Lange, 1996). The annual mean discharge for WY 1993 was $1.76 \mathrm{ft}^{3} / \mathrm{s}$ (Cruz and others, 1994); for WY 1994 was $1.37 \mathrm{ft}^{3} / \mathrm{s}$ (Borland and Ong, 1995); and for WY 1995 was $2.24 \mathrm{ft}^{3} / \mathrm{s}$ (Ortiz and Lange, 1996).

The water sampled at site 10 for the most part was a well-oxygenated, sodium calcium magnesium bicarbonate type. The median specific-conductance value was 108 , the median $\mathrm{pH}$ value was 7.8 , and the median DO percent of saturation was 98 . DS and most major constituents were in the low group; chloride was in the middle group; and silica was in the high group. The mean sulfate concentration of $2.4 \mathrm{mg} / \mathrm{L}$ was approximately 3.5 times larger than the weighted monthly mean sulfate concentration of $0.704 \mathrm{mg} / \mathrm{L}$ in precipitation during the high-intensity sampling phase for this area (National Atmospheric Deposition

Program, 1996). Silica concentrations were very high, and all measured concentrations were outside the range of what is normally expected in surface waters, 1 to 30 $\mathrm{mg} / \mathrm{L}$ (Hem, 1985). The minimum silica concentration detected at site $10,39 \mathrm{mg} / \mathrm{L}$, was equal to the maximum concentration detected at all other basic-fixed sites combined. These large silica concentrations are probably the result of weathering of volcanic tuff in the drainage basin.

The median concentrations of all nitrogen nutrients were below their respective MDL's. Total phosphorus was in the low group; dissolved phosphorus and orthophosphate were in the middle group. Dissolved iron was in the high group; dissolvediron concentrations were much larger than expected for well-oxygenated surface waters (Hem, 1985), possibly due to particulates and/or colloids that passed through a 0.45-micron filter (Kennedy and others, 1974).

Dissolved manganese was in the middle group. Summary statistics for field-property and chemicalanalyte data for site 10 are presented in table 23 .

Streamflow showed a moderate negative correlation to specific conductance $(-0.48)$, calcium $(-0.31)$, magnesium $(-0.35)$, sodium $(-0.61)$, bicarbonate $(-0.69)$, and fluoride $(-0.53)$, and no correlation to a moderate positive correlation to DS $(0.18)$, sulfate $(0.53)$, chloride $(0.37)$, the nutrients $(-0.05$ to 0.40$)$, dissolved iron (0.66), and dissolved manganese (0.48). Regression equations that relate selected water-quality data to selected field properties and time are presented in table 24 .

\section{Site 11 - Santa Fe River above Cochiti Lake, N. Mex.}

Site 11 is an indicator site for an urban watershed on a tributary that originates in the Sangre de Cristo Range, flows through Santa Fe, New Mexico, and drains to an area behind Cochiti Dam. This area may at times be inundated by Cochiti Lake, although this did not occur during the high-intensity sampling phase. The USGS streamflow-gaging station for this site is located approximately $0.8 \mathrm{mi}$ southeast of La Bajada, New Mexico, and 5.0 mi upstream from Cochiti Dam. All samples were collected by wading near the gage.

Major land uses in the 228- $\mathrm{mi}^{2}$ Santa Fe River Basin are forest and rangeland (U.S. Geological Survey, 1986); a number of abandoned mines are in the basin, including an abandoned uranium mine approximately $1.5 \mathrm{mi}$ upstream from site 11 . Because during most of the year a large percentage of the flow at this site is effluent from the Santa Fe WWTP, the site is classified as an urban land-use site. Major surficial deposits and bedrock types in this basin include Precambrian metamorphic rock and granite and Quaternary unconsolidated gravel, sand, and silt and lava (Dane and Bachman, 1965).

Streamflow at site 11 is seasonal; high flows caused by snowmelt usually occur in early to midspring. Summer storms also can cause flows as high as spring flows. Streamflow at this site is affected by diversions for municipal supply and irrigation. The annual mean discharge at site 11 for WY's 1970 to 1995 was $11.6 \mathrm{ft}^{3} / \mathrm{s}$ (Ortiz and Lange, 1996). The annual mean discharge for WY 1993 was $16.6 \mathrm{ft}^{3} / \mathrm{s}$ (Cruz and others, 1994); for WY 1994 was $11.6 \mathrm{ft}^{3} / \mathrm{s}$ (Borland and Ong, 1995); and for WY 1995 was 15.3 $\mathrm{ft}^{3} / \mathrm{s}$ (Ortiz and Lange, 1996). 


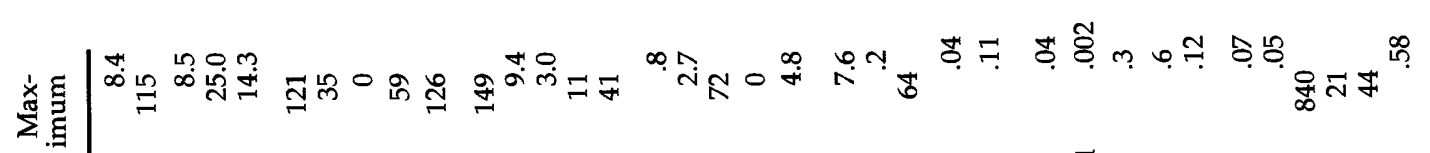


Table 24.--Regression equations for selected water-quality analytes with selected field properties and time for site 10 - Rito de Los Frijoles in Bandelier National Monument, N. Mex.

[Analyte: ${ }^{\circ} \mathrm{C}$, degrees Celsius; diss, dissolved; ortho, orthophosphate. Unit: $\mathrm{mg} / \mathrm{L}$, milligrams per liter; $\mu \mathrm{g} /$ L, micrograms per liter. Regression equation: $q$, streamflow, in cubic feet per second; sclog, base 10 logarithm of specific conductance, in microsiemens per centimeter at $25^{\circ} \mathrm{C}$; $\mathrm{pH}$, in standard $\mathrm{pH}$ units; sc, specific conductance, in microsiemens per centimeter at $25^{\circ} \mathrm{C}$; sea ${ }^{1}$, seasonality variable; temp, water temperature, in ${ }^{\circ} \mathrm{C}$; DO, dissolved-oxygen concentration, in $\mathrm{mg} / \mathrm{L}$; DOlog, base 10 logarithm of dissolvedoxygen concentration, in $\mathrm{mg} / \mathrm{L}$; qlog, base 10 logarithm of streamflow, in cubic feet per second. Adj $\mathrm{R}^{2}$, adjusted coefficient of determination (Ott, 1993). Method: MLR, multiple linear regression; KTR, Kendall-Theil robust line. --, not applicable]

\begin{tabular}{|c|c|c|c|c|}
\hline Analyte & Units & Regression Equation & Adj $R^{2}$ & Method \\
\hline $\begin{array}{l}\text { Solids, residue at } 180^{\circ} \mathrm{C} \\
\text { (dissolved solids) }\end{array}$ & $\mathrm{mg} / \mathrm{L}$ & $-511.83+7.928 q+352.80$ sclog $-12.970 p H$ & 0.614 & MLR \\
\hline Calcium & $\mathrm{mg} / \mathrm{L}$ & $10^{(-1.311+0.004 q+1.093 \text { sclog })}$ & .682 & MLR \\
\hline Magnesium & $\mathrm{mg} / \mathrm{L}$ & $10^{(0.078+0.0033 \mathrm{sc})}$ & .478 & MLR \\
\hline Sodium & $\mathrm{mg} / \mathrm{L}$ & $10^{(-24.24-0.075 \mathrm{qlog}-0.063 \mathrm{sc}+15.740 \mathrm{sclog}-0.014 \mathrm{sea})}$ & .698 & MLR \\
\hline Potassium & $\mathrm{mg} / \mathrm{L}$ & $10^{(0.14+0.022 q+0.008 \text { temp })}$ & .583 & MLR \\
\hline Bicarbonate, as $\mathrm{HCO}_{3}$ & $\mathrm{mg} / \mathrm{L}$ & $10^{(1.237-0.021 q+0.003 \mathrm{sc}+0.032 \mathrm{pH}-0.015 \text { sea })}$ & .829 & MLR \\
\hline Sulfate, as $\mathrm{SO}_{4}$ & $\mathrm{mg} / \mathrm{L}$ & $1.82+0.364 \mathrm{q}$ & .750 & MLR \\
\hline Chloride & $\mathrm{mg} / \mathrm{L}$ & $29.84+0.465 \mathrm{q}+2.692 \mathrm{DO}-53.491 \mathrm{DOlog}+0.571 \mathrm{sea}$ & .481 & MLR \\
\hline Fluoride & $\mathrm{mg} / \mathrm{L}$ & $10^{(-0.238-0.061 \mathrm{q}-0.050 \mathrm{DO}-0.106 \text { sea })}$ & .667 & MLR \\
\hline Silica, as $\mathrm{SiO}_{2}$ & $\mathrm{mg} / \mathrm{L}$ & $10^{(1.330+0.153 q \log -0.027 q+0.004 s c-0.018 \text { sea })}$ & .334 & MLR \\
\hline Phosphorus, total, as $\mathrm{P}$ & $\mathrm{mg} / \mathrm{L}$ & $10^{(-1.443+0.120 \mathrm{sea})}$ & -- & KTR \\
\hline $\begin{array}{l}\text { Phosphorus, diss, as } \mathrm{P} \\
\text { Phosphorus, ortho, }\end{array}$ & $\mathrm{mg} / \mathrm{L}$ & $10^{(-1.560+0.097 \mathrm{sea})}$ & - & KTR \\
\hline diss, as $P$ & $\mathrm{mg} / \mathrm{L}$ & $10.18+0.004 q+0.027 s c-6.364$ sclog $-0.019 p H+0.003$ sea & .467 & MLR \\
\hline Iron, diss & $\mu \mathrm{g} / \mathrm{L}$ & $10^{(-8.656+0.605 q \log -0.544 \mathrm{DO}+15.898 \mathrm{DO} \log +0.050 \text { temp })}$ & .693 & MLR \\
\hline Manganese, diss & $\mu \mathrm{g} / \mathrm{L}$ & $42.37+1.167 q-3.824 \mathrm{pH}-0.603 \mathrm{DO}-1.332$ sea & .524 & MLR \\
\hline
\end{tabular}

${ }^{1}$ sea $=\sin (T)+\cos (T)$ where $T$ equals the time, in months, from December 1, 1992, times 0.5236 . 
Two different types of water were detected at site 11. During most of the year, the water was a welloxygenated, sodium bicarbonate type. During high flows, however, calcium became the predominant cation and the water was a calcium to a calcium sodium bicarbonate type. This change in chemical type is due mainly to the percentage of effluent. During high flows, runoff upstream from Santa Fe was the major component of streamflow at site 11 , whereas during the remainder of the time, WWTP effluent was the major component of streamflow. The median specificconductance value was 622 , the median $\mathrm{pH}$ value was 8.5 , and the median DO percent of saturation was 102 .

DS and most major constituents were in the high group; calcium, magnesium, silica, and sulfate were in the middle group. The median concentrations of bicarbonate and potassium were the largest for any basic-fixed site. Because of anthropogenic influences, streamflow showed no correlation to moderate negative correlations with DS $(-0.31)$ and the major constituents $(-0.18$ to -0.61$)$. Chloride $(-0.45)$ and fluoride $(-0.61)$ showed the strongest correlations. During the times that WWTP effluent was a major component of flow, median concentrations of DS and major constituents were 1.7 to 4.4 times larger than those during periods of high flows.

Because of urban influences, median concentrations of most dissolved nutrients were larger at site 11 than at any other basic-fixed site. The median dissolved-ammonia concentration was larger at site 12 $(0.20$ to $0.06 \mathrm{mg} / \mathrm{L})$. The median concentrations of total ammonia plus organic nitrogen and total phosphorus at site 11 were the second largest median concentrations at any basic-fixed site. The nutrients showed no correlation to moderate negative correlations with streamflow $(0.13$ to -0.36$)$.

Dissolved iron and dissolved manganese were in the middle group. Dissolved-iron concentrations were larger than expected for well-oxygenated surface waters (Hem, 1985), possibly due to particulates and/or colloids that passed through a 0.45 -micron filter (Kennedy and others, 1974). Summary statistics for field-property and chemical-analyte data for site 11 are presented in table 25 . Regression equations that relate selected water-quality data to selected field properties and time are presented in table 26.

\section{Site 12 - Rio Grande at Isleta, N. Mex.}

Site 12 is an integrator site on the main stem at a bridge on State Highway 47 at Isleta, New Mexico.
Although there was no streamflow-gaging station at this site during the high-intensity sampling phase, daily streamflow records can be estimated for this period from records for the USGS streamflow-gaging station Rio Grande at Rio Bravo Bridge near Albuquerque, New Mexico (08330150), approximately $5 \mathrm{mi}$ upstream from site 12, and from inflow data for drains, arroyos, and the WWTP between the Rio Bravo Bridge and Isleta sites. Low-flow samples were collected by wading upstream from the bridge, and high-flow samples were collected from the upstream side of the bridge.

Because this site is located just downstream from Albuquerque, New Mexico, the dominant land use affecting water quality at the site is urban. Other major land uses in the 3,610- $\mathrm{mi}^{2}$ contributing drainage area between sites 9 and 12 are forest and rangeland (U.S. Geological Survey, 1986). In addition, the Rio Grande flood plain is farmed in the reach between Cochiti Dam, approximately $58 \mathrm{mi}$ upstream from site 12 , and the urban area. Major surficial deposits and bedrock types are Quaternary unconsolidated gravel, sand, and silt; tuff; and lava (Dane and Bachman, 1965).

Streamflow at site 12 is almost completely regulated by controlled releases from Cochiti Lake. High flows occur in late spring and early summer; however, storms in the drainage area downstream from Cochiti Lake can cause high flows at other times during the year. Long-term streamflow records are available for the USGS streamflow-gaging station Rio Grande at Albuquerque, New Mexico (08330000), about $10 \mathrm{mi}$ upstream from site 12. At this station, the annual mean discharge for WY's 1974 to 1995 was $1,485 \mathrm{ft}^{3} / \mathrm{s}$ (Ortiz and Lange, 1996). The annual mean discharge for WY 1993 was $1,893 \mathrm{ft}^{3} / \mathrm{s}$ (Cruz and others, 1994): for $\mathrm{WY}$ 1994 was $1,717 \mathrm{ft}^{3} / \mathrm{s}$ (Borland and Ong, 1995); and for WY 1995 was $2,149 \mathrm{ft}^{3} / \mathrm{s}$ (Ortiz and Lange, 1996).

The water sampled at site 12 for the most part was a well-oxygenated, calcium to calcium sodium bicarbonate type. The median specific-conductance value was 392 , the median $\mathrm{pH}$ value was 8.0 , and the median DO percent of saturation was 89 . Concentrations of DS and most major constituents showed statistically significant increases at the 95percent confidence interval compared with their corresponding concentrations at site 9. If instantaneous loads at the two sites are compared, however, only sodium, potassium, chloride, and fluoride showed 


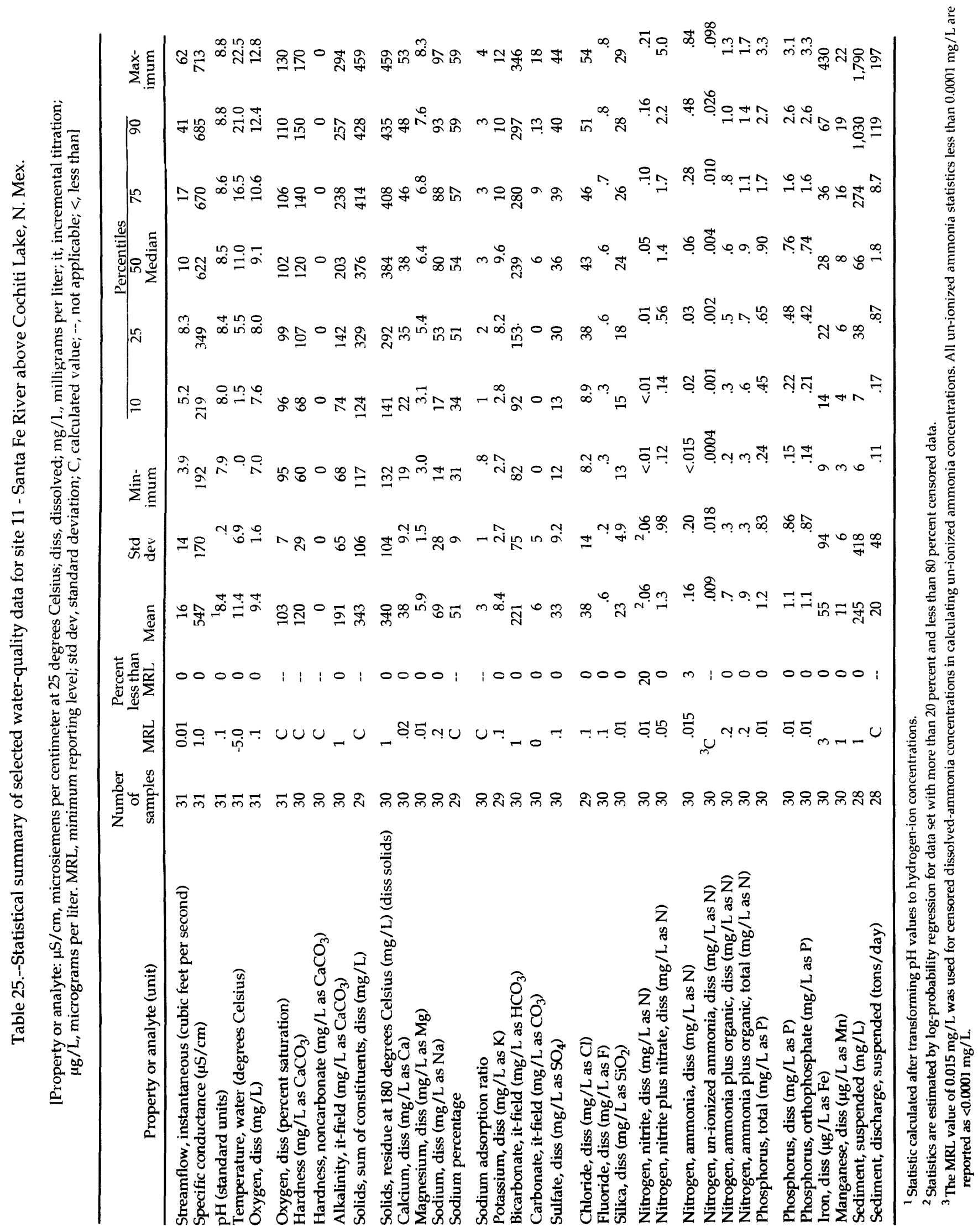


Table 26.--Regression equations for selected water-quality analytes with selected field properties and time for site 11 - Santa Fe River above Cochiti Lake, N. Mex.

[Analyte: ${ }^{\circ} \mathrm{C}$, degrees Celsius: $\mathrm{NO}_{2}$, nitrite: diss, dissolved; $\mathrm{NO}_{2}+\mathrm{NO}_{3}$, nitrite plus nitrate; amm, ammonia; amm + org, ammonia plus organic; ortho, orthophosphate. Unit: $\mathrm{mg} / \mathrm{L}$, milligrams per liter; $\mu \mathrm{g} / \mathrm{L}$. micrograms per liter. Regression equation: sc, specific conductance, in microsiemens per centimeter at $25^{\circ} \mathrm{C}$; sclog, base $10 \operatorname{logarithm}$ of specific conductance, in microsiemens per centimeter at $25^{\circ} \mathrm{C}$; temp, water temperature, in ${ }^{\circ} \mathrm{C} ; \mathrm{pH}$, in standard $\mathrm{pH}$ units; sea ${ }^{1}$, seasonality variable; qlog, base 10 logarithm of streamflow, in cubic feet per second; DOlog, base 10 logarithm of dissolved-oxygen concentration, in $\mathrm{mg} / \mathrm{L}$; DO, dissolved-oxygen concentration in $\mathrm{mg} / \mathrm{L}$. Adj $\mathrm{R}^{2}$, adjusted coefficient of determination (Ott, 1993). Method: MLR, multiple linear regression; KTR, Kendall-Theil robust line. --, not applicable]

\begin{tabular}{|c|c|c|c|c|}
\hline Analyte & Unit & Regression equation & dj $R^{2}$ & Method \\
\hline $\begin{array}{l}\text { Solids, residue at } 180^{\circ} \mathrm{C} \\
\text { (dissolved solids) }\end{array}$ & $\mathrm{mg} / \mathrm{L}$ & $10^{(1.058+0.0006 \mathrm{sc}+0.415 \mathrm{sclog})}$ & 0.987 & MLR \\
\hline Calcium & $\mathrm{mg} / \mathrm{L}$ & $10^{(-0.033+0.610 \text { sclog }-0.005 \text { temp })}$ & .956 & MLR \\
\hline Magnesium & $\mathrm{mg} / \mathrm{L}$ & $10^{(-0.228+0.0007 \mathrm{sc}+0.081 \mathrm{pH}-0.007 \text { temp }+0.021 \mathrm{sea})}$ & .959 & MLR \\
\hline Sodium & $\mathrm{mg} / \mathrm{L}$ & $10^{(-1.953-0.069 \mathrm{qlog}+1.401 \mathrm{sclog})}$ & .987 & MLR \\
\hline Potassium & $\mathrm{mg} / \mathrm{L}$ & $10^{(-1.621-0.086 \mathrm{qlog}+0.991 \mathrm{sclog}-0.010 \mathrm{DO})}$ & .963 & MLR \\
\hline Bicarbonate, as $\mathrm{HCO}_{3}$ & $\mathrm{mg} / \mathrm{L}$ & $10^{(4.907+0.001 \mathrm{sc}+0.184 \mathrm{DO}-4.916 \mathrm{DO} \log -0.012 \mathrm{temp})}$ & .978 & MLR \\
\hline Sulfate, as $\mathrm{SO}_{4}$ & $\mathrm{mg} / \mathrm{L}$ & $10^{(-4.176-0.0008 \mathrm{sc}+1.701 \mathrm{sclog}-0.098 \mathrm{DO}+2.496 \mathrm{DOlog}+0.025 \mathrm{sea})}$ & .969 & MLR \\
\hline Chloride & $\mathrm{mg} / \mathrm{L}$ & $10^{(-1.490-0.180 \mathrm{q} \log +1.176 \mathrm{sclog})}$ & .971 & MLR \\
\hline Fluoride & $\mathrm{mg} / \mathrm{L}$ & $10^{(-4.486-0.155 q \log +0.470 \mathrm{sclog}-0.214 \mathrm{DO}+5.236 \mathrm{DOlog}+0.007 \text { temp })}$ & .903 & MLR \\
\hline Silica, as $\mathrm{SiO}_{2}$ & $\mathrm{mg} / \mathrm{L}$ & $10^{(3.645+0.001 \mathrm{sc}-0.736 \mathrm{sclog}+0.079 \mathrm{pH}+0.138 \mathrm{DO}-3.066 \text { DOlog }-0.017 \mathrm{sea})}$ & .935 & MLR \\
\hline $\begin{array}{l}\text { Nitrogen, } \mathrm{NO}_{2} \text {, diss, as } \mathrm{N} \\
\text { Nitrogen, } \mathrm{NO}_{2}+\mathrm{NO}_{3}\end{array}$ & $\mathrm{mg} / \mathrm{L}$ & $-2.111+0.089 \mathrm{DO}$ & -- & KTR \\
\hline $\begin{array}{l}\text { diss, as } \mathrm{N} \\
\text { Nitrogen, amm, diss, }\end{array}$ & $\mathrm{mg} / \mathrm{L}$ & $10^{(-5.00 b+1.838 s c l o g)}$ & .652 & MLR \\
\hline $\begin{array}{l}\text { as } \mathrm{N} \\
\text { Nitrogen, amm + org, }\end{array}$ & $\mathrm{mg} / \mathrm{L}$ & $10^{(-1.262+1.278 \mathrm{qlog}-0.0065 \mathrm{sc}+7.559 \mathrm{sclog}+1.746 \mathrm{DO}-35.698 \mathrm{DOlog})}$ & .495 & MLR \\
\hline $\begin{array}{l}\text { diss, as } \mathrm{N} \\
\text { Nitrogen, amm + org, }\end{array}$ & $\mathrm{mg} / \mathrm{L}$ & $10^{(-9.407-0.0033 \mathrm{sc}+3.761 \mathrm{sclog}+0.819 \mathrm{DOlog})}$ & .633 & MLR \\
\hline total, as $\mathrm{N}$ & $\mathrm{mg} / \mathrm{L}$ & $\left.10^{(-12.45 t+0.013 q-0.005 s c+6.325 s c l o g}-0.233 p H\right)$ & .267 & MLR \\
\hline Phosphorus, total, as $\mathrm{P}$ & $\mathrm{mg} / \mathrm{L}$ & $\begin{aligned} 5.414+1.780 \mathrm{qlog} & +0.0175 \mathrm{sc}-11.028 \text { sclog } \\
& +12.303 \text { DOlog }+0.202 \text { temp }\end{aligned}$ & .579 & MLR \\
\hline $\begin{array}{l}\text { Phosphorus, diss, as } \mathrm{P} \\
\text { Phosphorus, ortho, }\end{array}$ & $\mathrm{mg} / \mathrm{L}$ & $10^{(6.145+0.008 s c-6.386 s c l o g}+0.536 \mathrm{pH}+0.163 \mathrm{DO}+0.049$ temp) & .647 & MLR \\
\hline diss, as $\mathrm{P}$ & $\mathrm{mg} / \mathrm{L}$ & $10^{(6.483+0.008 s c-6.498 s c l o g+0.518 p H+0.166 \mathrm{DO}+0.050 \text { temp })}$ & .625 & MLR \\
\hline Iron, diss & $\mu \mathrm{g} / \mathrm{L}$ & $6401.4-4.157 q+2.232 s c-2,769.6$ sclog & .629 & MLR \\
\hline Manganese, diss & $\mu \mathrm{g} / \mathrm{L}$ & $-23.196+3.498 \mathrm{DO}+2.602 \mathrm{sea}$ & .531 & MLR \\
\hline
\end{tabular}

${ }^{1}$ sea $=\sin (T)+\cos (T)$ where $T$ equals the time, in months, from December I, 1992, times 0.5236 . 
statistically significant increases. The significant increase in concentrations were due to a combination of increased loads and evapotranspiration of water between the sites. The significant increases in sodium, chloride, and possibly potassium and fluoride loads were the result of anthropogenic activities, such as discharges from WWTP's and irrigation-return flows. DS and all major constituents were in the middle group.

Nutrient concentrations at site 12 also were large as a result of anthropogenic activities; all nutrients were in the high group. The median dissolvedammonia concentration and the instantaneous loads of dissolved nutrients were the largest detected at any basic-fixed site. Concentrations of all nutrients were smallest during high spring flow and largest during low flow in late summer.

Dissolved iron and dissolved manganese were in the middle group. Summary statistics for field-property and chemical-analyte data for site 12 are presented in table 27. Regression equations that relate selected water-quality data to selected field properties and time are presented in table 28 .

\section{Site 13 - Rio Puerco near Bernardo, N. Mex.}

Site 13 is an integrator site near the mouth of an ephemeral tributary. The USGS streamflow-gaging station for this site was located on a bridge on former U.S. Highway 25 approximately $1.2 \mathrm{mi}$ southwest of Bernardo, New Mexico. A new gaging station, located about $400 \mathrm{ft}$ upstream from the bridge, was established after the high-intensity sampling phase. Low-flow samples were collected by wading. High-flow samples were collected from a cableway about $300 \mathrm{ft}$ downstream from the old gage or from the upstream side of a bridge on the present U.S. Highway 25 about $0.25 \mathrm{mi}$ downstream from the old gage.

Major land-use types in the $6,250-\mathrm{mi}^{2}$ contributing drainage basin include forest in the headwater areas and rangeland in the lower basin (U.S. Geological Survey, 1986). A large uranium mining area is located along the upper reaches of the Rio San Jose, the major tributary to the Rio Puerco (Ellis and others, 1993). Major bedrock types and surficial deposits include Triassic lava and sedimentary rock, Cretaceous sandstone and shale, and Quaternary lava and alluvium (Dane and Bachman, 1965).

Streamflow at site 13 usually results from snowmelt during the spring and storms during the remainder of the year; no flow is present for more than
50 percent of the year. During the high-intensity sampling phase, the highest annual instantaneous flows resulted from summer thunderstorms. The annual mean discharge at this site for WY's 1940 to 1995 was 43.3 $\mathrm{ft}^{3} / \mathrm{s}$ (Ortiz and Lange, 1996). The annual mean discharge for WY 1993 was $35.8 \mathrm{ft}^{3} / \mathrm{s}$ (Cruz and others. 1994); for WY 1994 was $23.6 \mathrm{ft}^{3} / \mathrm{s}$ (Borland and Ong, 1995); and for WY 1995 was $20.7 \mathrm{ft}^{3} / \mathrm{s}$ (Ortiz and Lange, 1996).

The water sampled at site 13 varied from a sodium sulfate type to a calcium sulfate type. Generally, the water was well oxygenated and had a median specific-conductance value of 1,680. a median $\mathrm{pH}$ value of 8.1, and a median DO percent of saturation of 100 . The calcium sulfate-type water was detected in runoff from late summer thunderstorms: however, the runoff from some thunderstorms was a sodium sulfate type. Because of the variation in bedrock and surficial deposits throughout the basin, the location of a storm appears to have had an influence on the predominant cation in storm runoff.

The median concentrations of DS and most major constituents detected at site 13 were the largest detected at any basic-fixed site during the highintensity sampling phase. Of the other major constituents, potassium and chloride were in the high group; bicarbonate was in the middle group; and the median silica concentration was the smallest detected at any site. The large DS and major-constituent concentrations may be caused by either of two processes. Suspended-sediment concentrations in the Rio Puerco are large and may result from channel bank erosion or overland flow erosion of the river terraces (Allen Gellis, U.S. Geological Survey, written commun., 1996). This erosion continually exposes fresh surfaces containing soluble materials as the finegrained insoluble detritus is mechanically washed away (Hem, 1985). In addition, in semiarid areas such as the lower part of the RIOG study unit, DS in precipitation and in ground water, brought to the surface by capillary action, are concentrated by evaporation or other mechanisms. These concentrated solids may then be deposited on the surface as a crust to be available for redissolution during the next precipitation event.

The three largest DS concentrations were detected during the winter months and coincided with the three smallest discharges sampled at site 13. The large concentrations in these samples were probably 


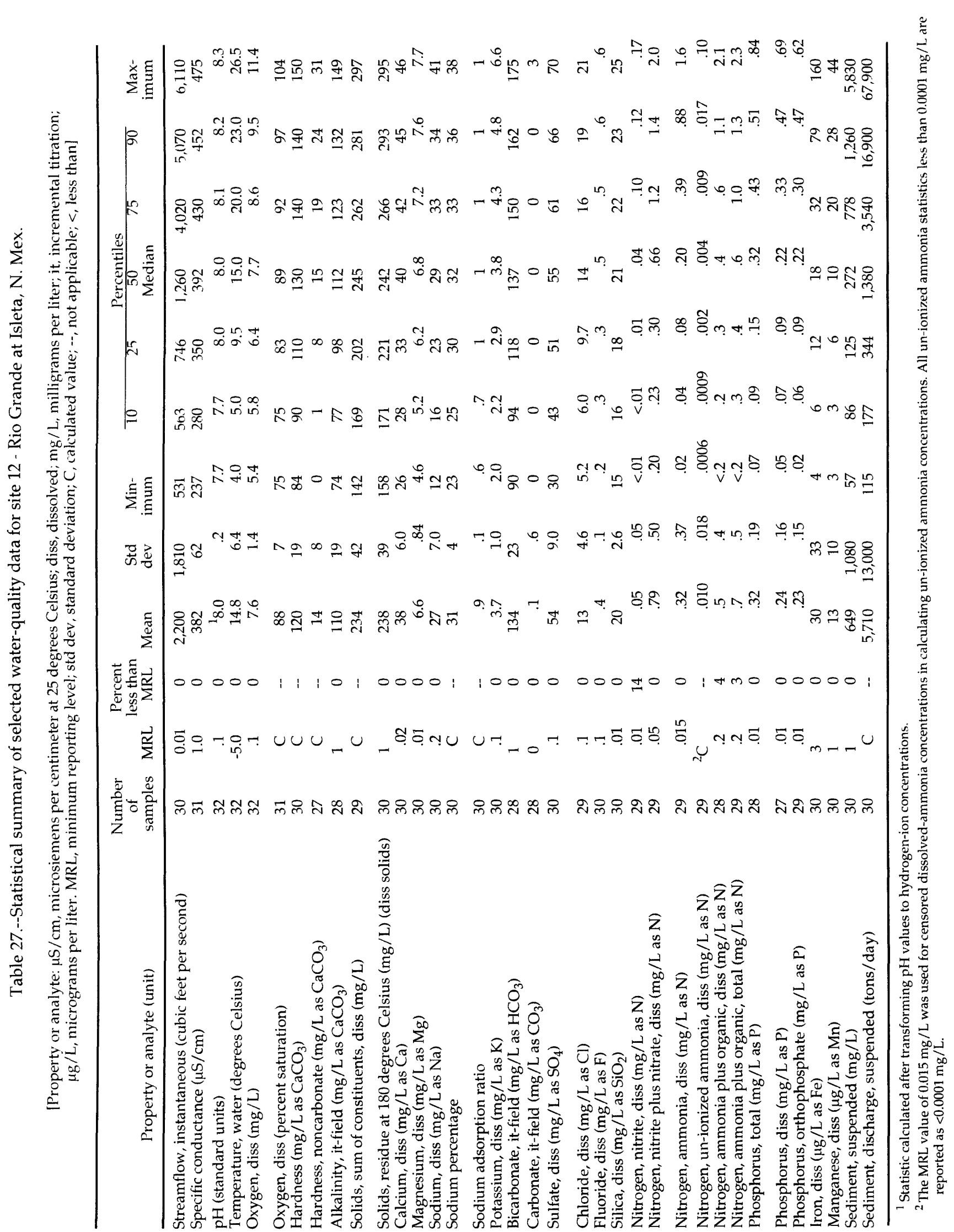


Table 28.--Regression equations for selected water-quality analytes with selected field properties and time for site 12 - Rio Grande at Isleta, N. Mex.

[Analyte: ${ }^{\circ} \mathrm{C}$, degrees Celsius; $\mathrm{NO}_{2}$, nitrite; diss, dissolved; $\mathrm{NO}_{2}+\mathrm{NO}_{3}$, nitrite plus nitrate: amm, ammonia; amm + org, ammonia plus organic; ortho, orthophosphate. Unit: $\mathrm{mg} / \mathrm{L}$, milligrams per liter; $\mu \mathrm{g} /$ $\mathrm{L}$, micrograms per liter. Regression equation: sc, specific conductance, in microsiemens per centimeter at $25{ }^{\circ} \mathrm{C}$; temp, water temperature, in ${ }^{\circ} \mathrm{C}$; sclog, base 10 logarithm of specific conductance, in microsiemens per centimeter at $25^{\circ} \mathrm{C}$; DOlog, base 10 logarithm of dissolved-oxygen concentration, in mg/L; sea ${ }^{1}$, seasonality variable; $\mathrm{pH}$, in standard $\mathrm{pH}$ units; qlog, base 10 logarithm of streamflow, in cubic feet per second; q, streamflow, in cubic feet per second; DO, dissolved-oxygen concentration, in mg/L. Adj $R^{2}$, adjusted coefficient of determination (Ott, 1993). Method: MLR, multiple linear regression;

KTR, Kendall-Theil robust line. --, not applicable]

\begin{tabular}{|c|c|c|c|c|}
\hline Analyte & Unit & Regression equation & Adj $R^{2}$ & Method \\
\hline $\begin{array}{l}\text { Solids, residue at } 180^{\circ} \mathrm{C} \\
\text { (dissolved solids) }\end{array}$ & $\mathrm{mg} / \mathrm{L}$ & $32.47+0.572 \mathrm{sc}-0.808$ temp & 0.924 & MLR \\
\hline Calcium & $\mathrm{mg} / \mathrm{L}$ & $-85.68+53.412$ sclog -14.776 DOlog - 2.279 sea & .896 & MLR \\
\hline Magnesium & $\mathrm{mg} / \mathrm{L}$ & $10^{(-3.879-0.0017 \mathrm{sc}+1.924 \mathrm{sclog}+0.048 \mathrm{pH}-0.014 \text { sea })}$ & .865 & MLR \\
\hline Sodium & $\mathrm{mg} / \mathrm{L}$ & $10^{(-2.763+1.625 \mathrm{sclog})}$ & .926 & MLR \\
\hline Potassium & $\mathrm{mg} / \mathrm{L}$ & $10^{(-2.132+1.045 \mathrm{sclog})}$ & .481 & MLR \\
\hline Bicarbonate, as $\mathrm{HCO}_{3}$ & $\mathrm{mg} / \mathrm{L}$ & $10^{(0.658+0.613 \text { sclog }-0.125 \text { DOlog }-0.040 \text { sea })}$ & .936 & MLR \\
\hline Sulfate, as $\mathrm{SO}_{4}$ & $\mathrm{mg} / \mathrm{L}$ & $10^{(-2.380+0.074 \mathrm{qlog}+1.236 \mathrm{sclog}+0.086 \mathrm{pH})}$ & .875 & MLR \\
\hline Chloride & $\mathrm{mg} / \mathrm{L}$ & $10(0.002+0.003 \mathrm{sc}-0.010$ temp +0.078 sea $)$ & .901 & MLR \\
\hline Fluoride & $\mathrm{mg} / \mathrm{L}$ & $10^{(0.654-0.00003 q+0.001 s c-0.167 p H)}$ & .756 & MLR \\
\hline Silica, as $\mathrm{SiO}_{2}$ & $\mathrm{mg} / \mathrm{L}$ & $10^{(0.907-0.00001 q+0.363 \operatorname{sclog}-0.063 \mathrm{pH})}$ & .776 & MLR \\
\hline \multicolumn{2}{|c|}{$\begin{array}{l}\text { Nitrogen, } \mathrm{NO}_{2} \text {, diss, as } \mathrm{N} \mathrm{mg/L} \\
\text { Nitrogen, } \mathrm{NO}_{2}+\mathrm{NO}_{3}\end{array}$} & $10^{(-1.900-1.055 \mathrm{qlog})}$ & -- & KTR \\
\hline $\begin{array}{l}\text { diss, as } \mathrm{N} \\
\text { Nitrogen, amm, diss, }\end{array}$ & $\mathrm{mg} / \mathrm{L}$ & $10^{(-3.502-0.0001 q+1.368 \text { sclog })}$ & .782 & MLR \\
\hline as $\mathrm{N}$ & $\mathrm{mg} / \mathrm{L}$ & $\begin{array}{c}10^{(-27.329+0.0002 q-1.961 q \log -0.0227 s c+18.04 \mathrm{sclog}} \\
-4.966 \text { DOlog }-0.073 \text { temp })\end{array}$ & .755 & MLR \\
\hline $\begin{array}{l}\text { Nitrogen, amm + org, } \\
\text { diss, as } \mathrm{N}\end{array}$ & $\mathrm{mg} / \mathrm{L}$ & $10^{(-15.836+0.0002 q-1.837 q \log -0.015 \mathrm{sc}+10.091 \mathrm{sclog}+0.595 \mathrm{pH}}$ & & \\
\hline $\begin{array}{l}\text { Nitrogen, amm + org, } \\
\text { total, as } \mathrm{N}\end{array}$ & $\mathrm{mg} / \mathrm{L}$ & $\begin{array}{c}17.565+0.0002 \mathrm{q}-1.687 \mathrm{qlog}+0.810 \mathrm{DO}-19.754 \text { DOlog } \\
-0.059 \text { temp }\end{array}$ & .643 & MLR \\
\hline Phosphorus, total, as $\mathrm{P}$ & $\mathrm{mg} / \mathrm{L}$ & $10^{(1.777-0.740 \mathrm{qlog})}$ & .804 & MLR \\
\hline $\begin{array}{l}\text { Phosphorus, diss, as P } \\
\text { Phosphorus, ortho, }\end{array}$ & $\mathrm{mg} / \mathrm{L}$ & $10^{(2.424-0.821 \text { qlog }-0.606 \text { DOlog })}$ & .898 & MLR \\
\hline diss, as $\mathrm{P}$ & $\mathrm{mg} / \mathrm{L}$ & $10^{(-21.364-0.357 \mathrm{q} \log -0.012 \mathrm{sc}+11.194 \mathrm{sclog}-0.368 \mathrm{pH}}$ & & \\
\hline Jro & $r / I$ & $10(0.035+0.0003 q-1.783 q$ log -2.431 sclog $-1.433 \mathrm{DO}+26.815$ DOlog $)$ & .885 & MLR \\
\hline Manganese, diss & $\mu \mathrm{g} / \mathrm{L}$ & $\begin{array}{l}10^{(0.033+0.0003 q-1 . / 83 \mathrm{q} \log -2.431 \mathrm{sclog}-1.433 \mathrm{DU}+26.813 \mathrm{DUlog})} \\
10^{(2.883-0.461 \mathrm{q} \log -0.028 \text { temp })}\end{array}$ & .560 & MLR \\
\hline
\end{tabular}

${ }^{1}$ sea $=\sin (T)+\cos (T)$ where $T$ equals the time, in months, from December 1, 1992, times 0.5236. 
caused by the redissolution of the solids concentrated by freezing. The sample with the fourth largest DS concentration was runoff from a summer storm.

The median concentrations of total ammonia plus organic nitrogen and total phosphorus at site 13 were the largest and the median concentration of $\mathrm{NO}_{2}$ $+\mathrm{NO}_{3}$ was the second largest detected at any basicfixed site. These three nutrients showed no correlation to moderate positive correlation to streamflow $(0.27$ to $0.58)$. The large difference in median concentrations between total $(14 \mathrm{mg} / \mathrm{L})$ and dissolved ammonia plus organic nitrogen $(0.3 \mathrm{mg} / \mathrm{L})$ and between total $(2.7 \mathrm{mg} / \mathrm{L})$ and dissolved phosphorus $(0.02 \mathrm{mg} / \mathrm{L})$ indicates that most of the nitrogen and phosphorus are in the particulate phase. The larger concentrations of total ammonia plus organic nitrogen and total phosphorus showed a dual relation to suspendedsediment concentration. Most samples had a linear relation between the concentrations; about one-third of the samples, however, appear to have no relation. Most of these samples were collected in the spring of 1993 and the summer of 1995 . The reason for these different relations could not be explained from the available data.

The larger $\mathrm{NO}_{2}+\mathrm{NO}_{3}$ concentrations were detected in samples of runoff from summer storms. These larger concentrations are probably the result of dissolution of nitrates deposited in the basin by atmospheric deposition and animal manure (Anderholm and others, 1995). Most dissolvednitrogen nutrients were in the high group; dissolved phosphorus was in the low group. The median concentrations of $\mathrm{NO}_{2}$ and orthophosphate were below their respective MDL's.

Dissolved iron and dissolved manganese were in the low group. Summary statistics for field-property and chemical-analyte data for site 13 are presented in table 29. Regression equations that relate selected water-quality data to selected field properties and time are presented in table 30 .

\section{Site 14 - Rio Grande Conveyance Channel at San Marcial, N. Mex.}

Site 14 is at the USGS streamflow-gaging station on the Rio Grande Conveyance Channel about $1 \mathrm{mi}$ downstream from the former site of San Marcial, New Mexico. Low-flow samples were collected by wading near the gage, and high-flow samples were collected from a cableway downstream from the gage.
Because of the anthropogenic origins of the conveyance channel, site 14 is not considered to have a drainage basin. However, the conveyance channel discharges water to and receives water from the system of irrigation canals and drains that serve the agricultural fields and Bosque del Apache National Wildlife Refuge between San Acacia, New Mexico, and Elephant Butte Reservoir.

The conveyance channel was designed to carry the entire flow of the Rio Grande when river streamflow is below $2,000 \mathrm{ft}^{3} / \mathrm{s}$ (Bureau of Reclamation, 1977). Because of sedimentation problems in the lowest reaches of the channel due to high flows, however, diversions to the conveyance channel from the Rio Grande were suspended in March 1985 (Bureau of Reclamation, 1997). During the highintensity sampling phase, all flow in the conveyance channel was from ground-water inflow or return flows from irrigation canals and drains. High flows were in late spring and early summer and coincided with the largest diversions from the Rio Grande to the irrigation-canal system. From November through February, during each winter of the high-intensity sampling phase, water was not diverted for irrigation, and streamflow at site 14 was mostly ground-water inflow to the conveyance channel or irrigation drains. All irrigation canals and drains west of the Rio Grande in this reach eventually discharge to the conveyance channel south of the wildlife refuge, upstream from site 14. The annual mean discharge at site 14 for WY's 1986 to 1995 was $313 \mathrm{ft}^{3} / \mathrm{s}$. The annual mean discharge for WY 1993 was $329 \mathrm{ft}^{3} / \mathrm{s}$ (Cruz and others, 1994); for WY 1994 was $345 \mathrm{ft}^{3} / \mathrm{s}$ (Borland and Ong, 1995); and for WY 1995 was $354 \mathrm{ft}^{3} / \mathrm{s}$ (Ortiz and Lange, 1996).

The water sampled at site 14 for the most part was a well-oxygenated, sodium to sodium calcium bicarbonate sulfate chloride type. The median specificconductance value was 867 , the median $\mathrm{pH}$ value was 8.1 and the median DO percent of saturation was 93 . DS and most major constituents were in the high group; fluoride and silica were in the middle group. Specific conductance $(-0.45)$, DS $(-0.41)$, and most major constituents $(-0.38$ to -0.60$)$ showed moderate negative correlations with streamflow; chloride (0.27) and fluoride $(-0.21)$ showed no correlation to streamflow. The largest concentrations of DS and most major constituents were detected during low flow in the winter months, and the smallest concentrations were detected during mid- to late summer. 


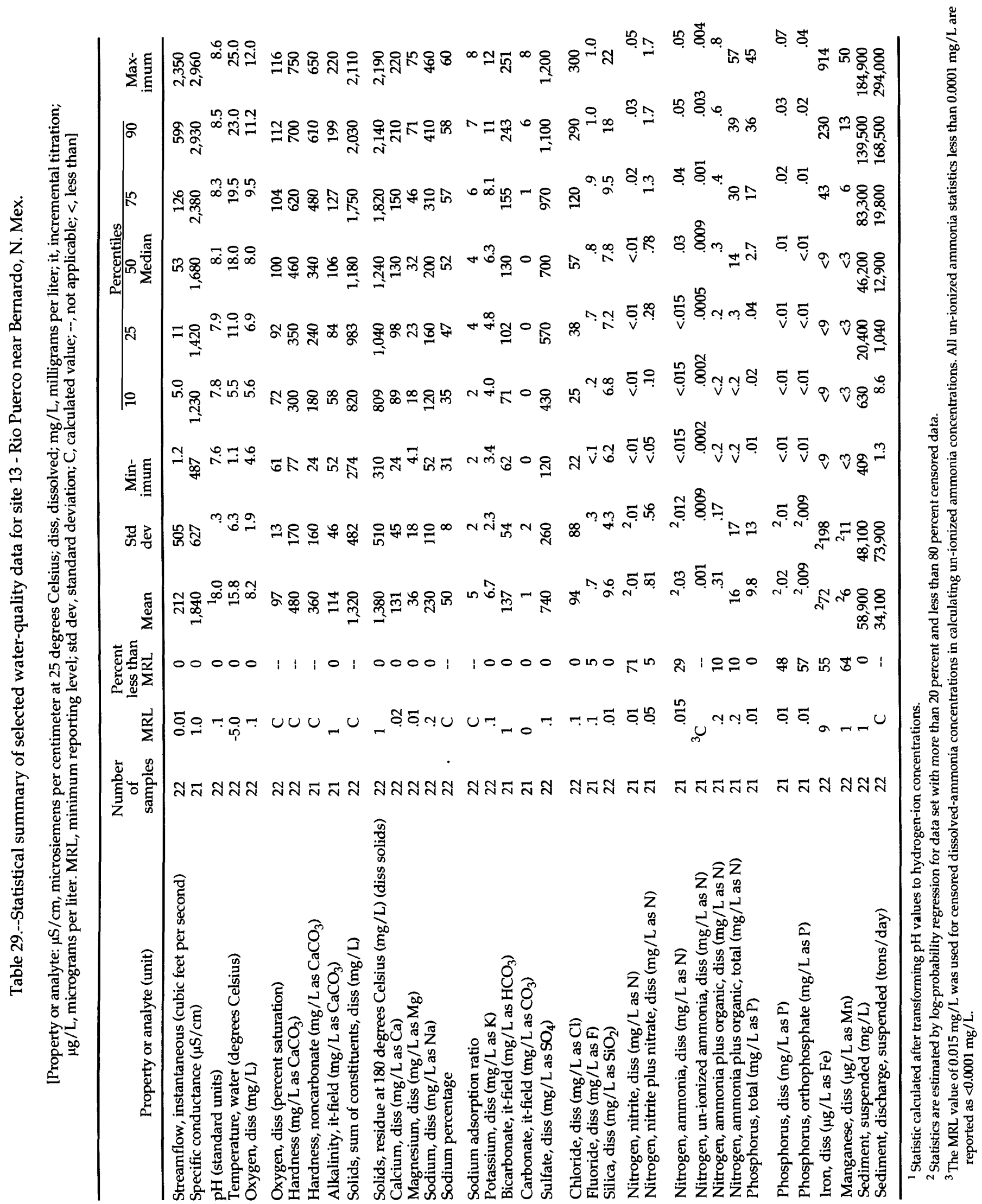


Table 30.--Regression equations for selected water-quality analytes with selected field properties and time for site 13 - Rio Puerco near Bernardo, N. Mex.

[Analyte: ${ }^{\circ} \mathrm{C}$, degrees Celsius; $\mathrm{NO}_{2}+\mathrm{NO}_{3}$, nitrite plus nitrate; diss, dissolved; amm + org, ammonia plus organic. Unit: $\mathrm{mg} / \mathrm{L}$, milligrams per liter. Regression equation: sclog, base 10 logarithm of specific conductance. in microsiemens per centimeter as $25^{\circ} \mathrm{C}$; sc, specific conductance, in microsiemens per centimeter at $25^{\circ} \mathrm{C}$; $\mathrm{pH}$, in standard $\mathrm{pH}$ units; $\mathrm{DO}$, dissolved-oxygen concentration, in $\mathrm{mg} / \mathrm{L}$; DOlog, base

10 logarithm of dissolved-oxygen concentration, in $\mathrm{mg} / \mathrm{L}$; sea ${ }^{1}$, seasonality variable; q, streamflow, in cubic feet per second; temp, water temperature, in ${ }^{\circ} \mathrm{C}$; qlog, base 10 logarithm of streamflow, in cubic feet per second. Adj $\mathrm{R}^{2}$, adjusted coefficient of determination (Ott, 1993). Method: MLR, multiple linear regression; KTR, Kendall-Theil robust line. --, not applicable]

\begin{tabular}{|c|c|c|c|c|}
\hline Analyte & Unit & Regression equation & Adj $R^{2}$ & Method \\
\hline $\begin{array}{l}\text { Solids, residue at } 180^{\circ} \mathrm{C} \\
\text { (dissolved solids) }\end{array}$ & $\mathrm{mg} / \mathrm{L}$ & $10^{(-0.564+1.132 \mathrm{sclog})}$ & 0.978 & MLR \\
\hline Calcium & $\mathrm{mg} / \mathrm{L}$ & $10^{(-1.924+1.215 \mathrm{sclog}-0.223 \mathrm{pH}-0.247 \mathrm{DO}+4.332 \mathrm{DOlog})}$ & .921 & MLR \\
\hline Magnesium & $\mathrm{mg} / \mathrm{L}$ & $10^{(-3.745+1.510 \mathrm{sclog}-0.360 \text { DOlog }+0.046 \mathrm{sea})}$ & .960 & MLR \\
\hline Sodium & $\mathrm{mg} / \mathrm{L}$ & $-17.64+0.132 \mathrm{sc}+63.725 \mathrm{pH}+71.916 \mathrm{DO}-1,223.86$ DOlog & .914 & MLR \\
\hline Potassium & $\mathrm{mg} / \mathrm{L}$ & $10^{(2.138+0.00016 \mathrm{sc}-0.2004 \mathrm{pH})}$ & .414 & MLR \\
\hline Bicarbonate, as $\mathrm{HCO}_{3}$ & $\mathrm{mg} / \mathrm{L}$ & $110.4+100.47 \mathrm{sclog}+42.494 \mathrm{pH}+98.34 \mathrm{DO}-1,607.17 \mathrm{DOlog})$ & 5) .856 & MLR \\
\hline Sulfate, as $\mathrm{SO}_{4}$ & $\mathrm{mg} / \mathrm{L}$ & $10^{(-3.457+0.00005 q+1.444 \text { sclog }-0.229 \mathrm{DO}+3.843 \text { DOlog })}$ & .973 & MLR \\
\hline Chloride & $\mathrm{mg} / \mathrm{L}$ & $1,744.18-0.0657 q+242.78 \mathrm{DO}-4,021.52$ DOlog & .852 & MLR \\
\hline Fluoride & $\mathrm{mg} / \mathrm{L}$ & $10^{(-12.259-0.0004 q-0.001 s c+4.332 s c l o g}-0.007$ temp $)$ & .944 & MLR \\
\hline Silica, as $\mathrm{SiO}_{2}$ & $\mathrm{mg} / \mathrm{L}$ & $10^{(1.122-0.103 \mathrm{q} \log )}$ & .226 & MLR \\
\hline $\begin{array}{l}\text { Nitrogen, } \mathrm{NO}_{2}+\mathrm{NO}_{3}, \\
\text { diss as } \mathrm{N} \\
\text { Nitrogen, amm + org, }\end{array}$ & $\mathrm{mg} / \mathrm{L}$ & $-0.189+0.565 q \log$ & -- & KTR \\
\hline $\begin{array}{l}\text { diss, as } \mathrm{N} \\
\text { Nitrogen, amm + org, }\end{array}$ & $\mathrm{mg} / \mathrm{L}$ & $10^{(-0.689+0.097 \mathrm{q} \log )}$ & -- & KTR \\
\hline total, as $\mathrm{N}$ & $\mathrm{mg} / \mathrm{L}$ & $10^{(0.301+0.492 \mathrm{q} \log )}$ & -- & KTR \\
\hline Phosphorus, total, as $\mathrm{P}$ & $\mathrm{mg} / \mathrm{L}$ & $10^{(24.074-2.932 \mathrm{pH})}$ & .302 & MLR \\
\hline
\end{tabular}

${ }^{1}$ sea $=\sin (T)+\cos (T)$ where $T$ equals the time, in months, from December 1, 1992, times 0.5236. 
Most nitrogen nutrients and total phosphorus were in the middle group; dissolved phosphorus and orthophosphate were in the high group. The median concentrations of $\mathrm{NO}_{2}$ and dissolved ammonia plus organic nitrogen were below their respective MDL's. Dissolved nutrients ( 0 to 0.15 ) showed no correlation to streamflow, whereas total nutrients $(0.31$ and 0.37$)$ showed moderate positive correlations.

Dissolved iron and dissolved manganese were in the low group. Summary statistics for the fieldproperty and chemical-analyte data for site 14 are presented in table 31 . Regression equations that relate selected water-quality data to selected field properties and time are presented in table 32 .

\section{Site 15 - Rio Grande Floodway at San Marcial, N. Mex.}

Site 15 is an integrator site on the main stem approximately $1.1 \mathrm{mi}$ downstream from the former site of San Marcial, New Mexico. The USGS streamflowgaging station for this site is located on a pier of the railroad bridge crossing the river at this location. Lowflow samples were collected by wading in the vicinity of the gage, and high-flow samples were collected from a cableway about $400 \mathrm{ft}$ upstream from the gage.

The contributing drainage area between sites 12 and 15 is $10,200 \mathrm{mi}^{2}$, of which approximately 61 percent is in the Rio Puerco Basin. Major land use in this area, excluding the Rio Puerco Basin, is rangeland (U.S. Geological Survey, 1986). In the Rio Grande flood plain, however, agricultural land use is predominant, and some small areas of urban land use are along the river in the upper part of this reach. Major surficial deposits and bedrock types in this area excluding the Rio Puerco drainage basin are Quaternary unconsolidated gravel, sand, and silt and lava (Dane and Bachman, 1965).

Streamflow at site 15 is controlled by releases from reservoirs and diversions for irrigation upstream except during high flow on ephemeral tributaries. The Rio Grande Floodway is the stabilized natural river channel designed to carry only the portion of streamflow that exceeds the $2,000-\mathrm{ft}^{3} / \mathrm{s}$ capacity of the conveyance channel; since March 1985, however, the floodway carries most of the streamflow that is not diverted for irrigation (Bureau of Reclamation, 1997). Sustained high flows were in late spring and early summer, whereas there was no flow at this site during part of July 1994 and August 1995. The annual mean discharge at this site for WY's I986 to 1995 was 1,099 $\mathrm{ft}^{3} / \mathrm{s}$. The annual mean discharge for WY 1993 was I,404 $\mathrm{ft}^{3} / \mathrm{s}$ (Cruz and others, 1994); for WY 1994 was $1,279 \mathrm{ft}^{3} / \mathrm{s}$ (Borland and Ong, 1995); and for WY 1995 was $1,560 \mathrm{ft}^{3} / \mathrm{s}$ (Ortiz and Lange, 1996). The annual mean discharge for the sum of streamflows in the conveyance channel and floodway for WY's 1986 to 1995 was $1,412 \mathrm{ft}^{3} / \mathrm{s}$. The annual mean discharge for WY I 993 was 1,733 $\mathrm{ft}^{3} / \mathrm{s}$ (Cruz and others, 1994); for WY 1994 was $1,624 \mathrm{ft}^{3} / \mathrm{s}$ (Borland and Ong, 1995); and for WY 1995 was $1,914 \mathrm{ft}^{3} / \mathrm{s}$ (Ortiz and Lange, I996).

The water sampled at site 15 was well oxygenated and mainly a calcium sodium bicarbonate type; the composition. however, ranged from a calcium bicarbonate to a calcium sodium sulfate type. The calcium bicarbonate water occurred during high spring flows, whereas the calcium sodium sulfate water was associated with storms on tributaries during the late summer. The median specific-conductance value was 482 , the median $\mathrm{pH}$ value was 8.2 , and the median DO percent of saturation was 98 .

DS and most major constituents were in the middle group; calcium was in the high group. The largest concentrations of DS and most major constituents were detected in samples associated with storms on tributaries. These samples also contained the largest instantaneous loads, although most of the annual DS load originated in the main stem upstream from site 12. Specific conductance (-0.52), DS (-0.48), and the major constituents $(-0.30$ to -0.59$)$ showed moderate negative correlations with streamflow.

Most nutrients were in the high group; dissolved ammonia was in the middle group. The median concentrations of $\mathrm{NO}_{2}$ and dissolved ammonia plus organic nitrogen were below their respective MDL's. Most nutrients showed no correlation with streamflow, whereas $\mathrm{NO}_{2}+\mathrm{NO}_{3}(-0.33)$ and orthophosphate $(-0.30)$ showed moderate negative correlations to streamflow. $\mathrm{NO}_{2}+\mathrm{NO}_{3}$ concentrations were largest during low flow, whereas the largest concentrations of total ammonia plus organic nitrogen, $23 \mathrm{mg} / \mathrm{L}$, and total phosphorus, $9.5 \mathrm{mg} / \mathrm{L}$, resulted from a storm in the Rio Puerco drainage basin.

Dissolved iron and dissolved manganese were in the low group. The median dissolved-manganese concentration was the smallest for any basic-fixed site. Summary statistics for the field-property and chemicalanalyte data for site 15 are presented in table 33 . Regression equations that relate selected water-quality data to selected field properties and time are presented in table 34. 


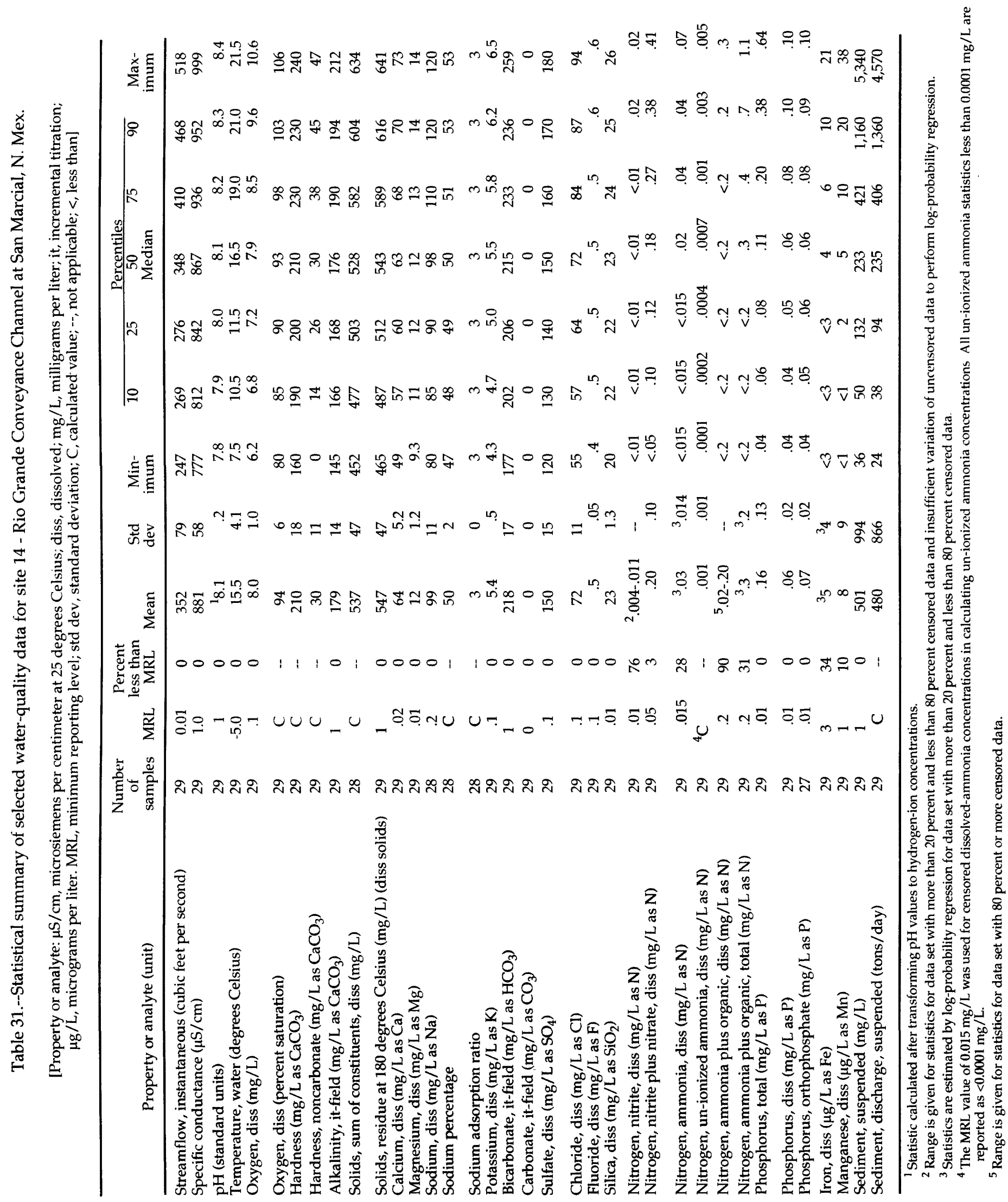


Table 32.--Regression equations for selected water-quality analytes with selected field properties and time for site 14 - Rio Grande Conveyance Channel at San Marcial, N. Mex.

[Analyte: ${ }^{\circ} \mathrm{C}$, degrees Celsius; $\mathrm{NO}_{2}+\mathrm{NO}_{3}$, nitrite plus nitrate; diss, dissolved; ortho, orthophosphate. Unit: $\mathrm{mg} / \mathrm{L}$, milligrams per liter; $\mu \mathrm{g} / \mathrm{L}$, micrograms per liter. Regression equation: sc, specific conductance, in microsiemens per centimeter at $25^{\circ} \mathrm{C}$; q, streamflow, in cubic feet per second; sclog, base 10 logarithm of specific conductance, in microsiemens per centimeter at $25^{\circ} \mathrm{C} ; \mathrm{pH}$, in standard $\mathrm{pH}$ units; sea ${ }^{\mathrm{I}}$, seasonality variable; temp, water temperature, in ${ }^{\circ} \mathrm{C}$; qlog, base 10 logarithm of streamflow, in cubic feet per second;

DO, dissolved-oxygen concentration, in $\mathrm{mg} / \mathrm{L}$; DOlog, base 10 logarithm of dissolved-oxygen concentration, in mg/L. Adj $\mathrm{R}^{2}$, adjusted coefficient of determination (Ott, 1993). Method: MLR, multiple linear regression; KTR, Kendall-Theil robust line. --, not applicable]

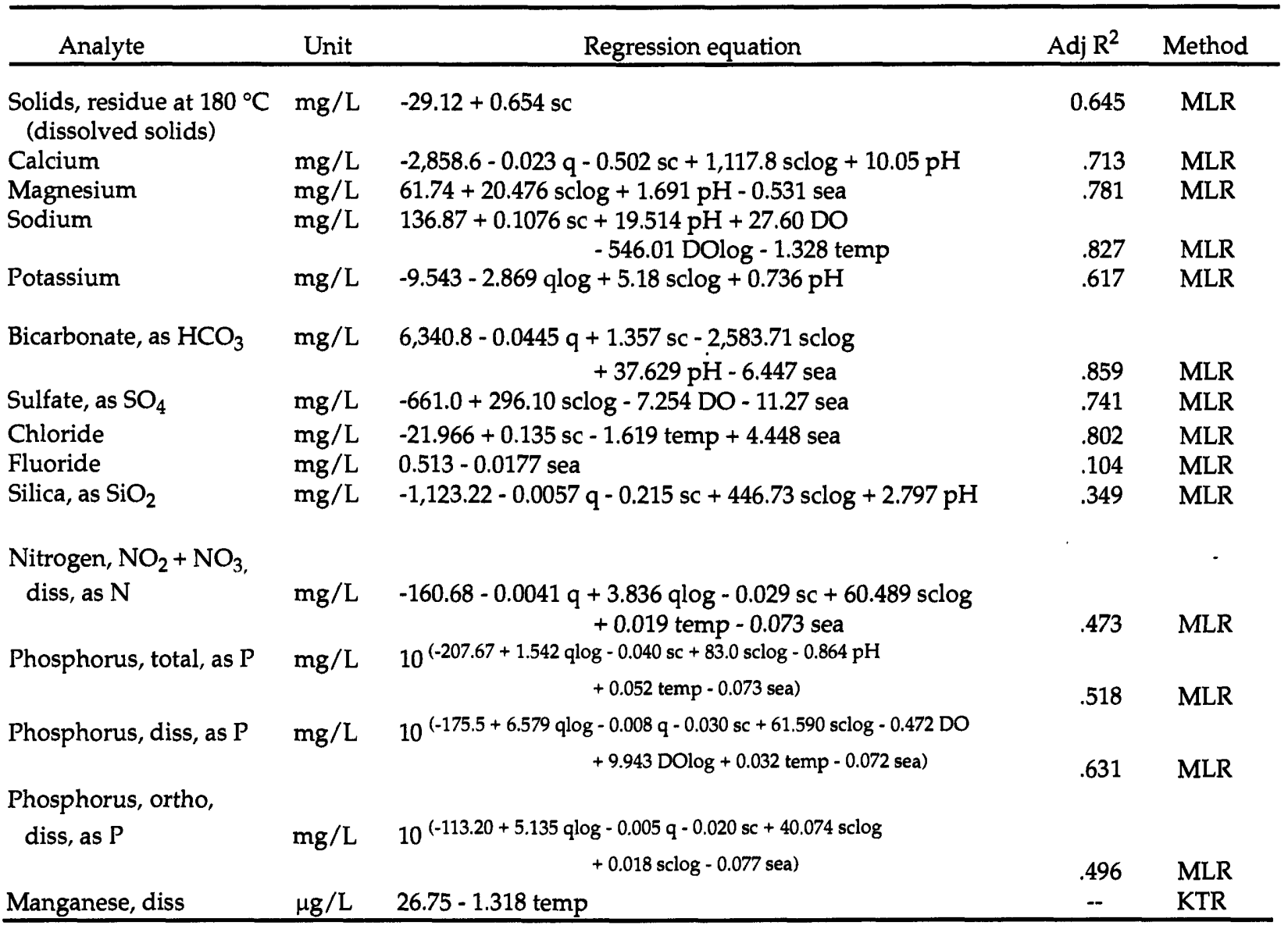

${ }^{1} \operatorname{sea}=\sin (T)+\cos (T)$ where $T$ equals the time, in months, from December 1,1992 , times 0.5236. 


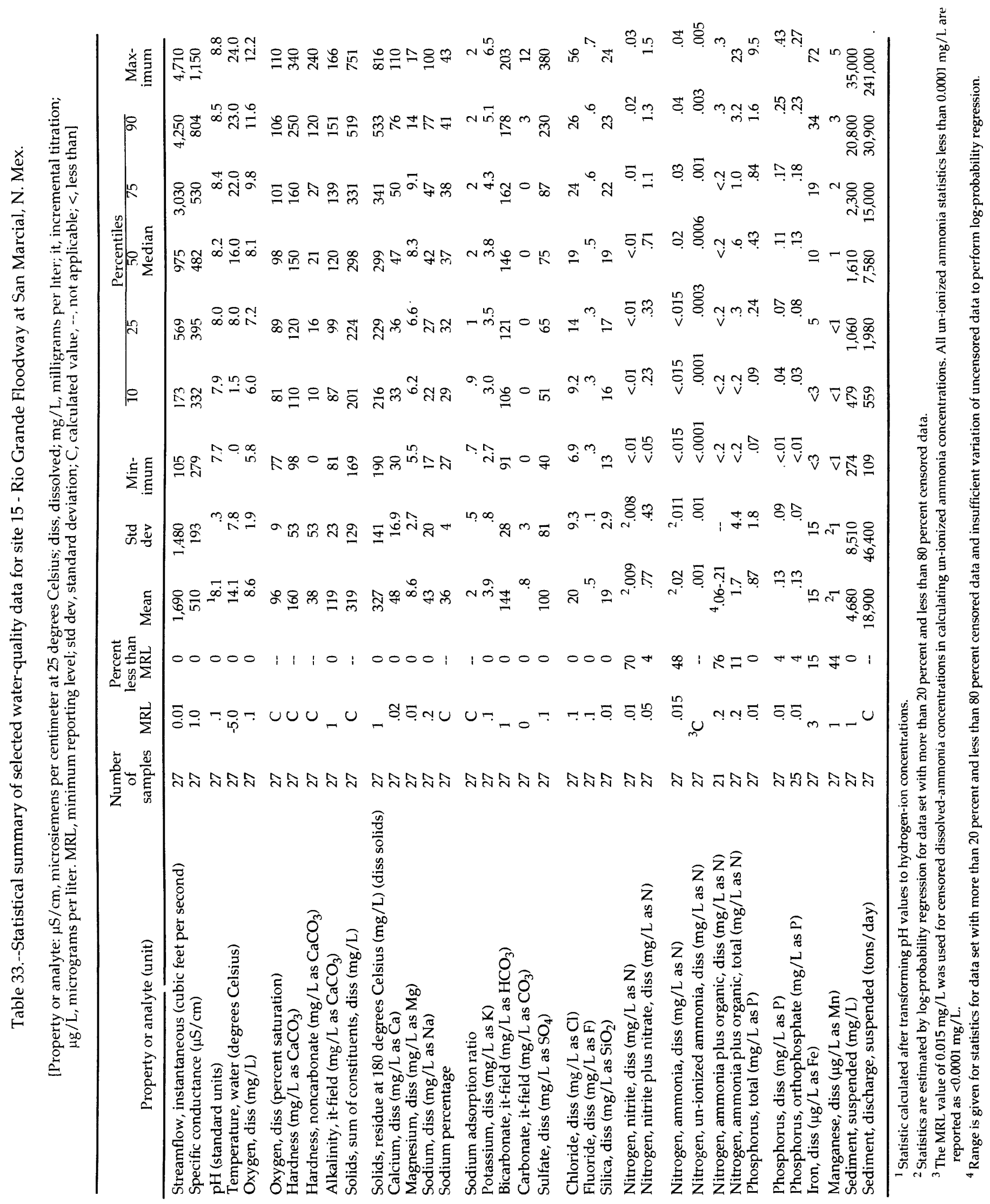


Table 34.--Regression equations for selected water-quality analytes with selected field properties and time for site 15 - Rio Grande Floodway at San Marcial, N. Mex.

[Analyte: ${ }^{\circ} \mathrm{C}$, degrees Celsius; $\mathrm{NO}_{2}+\mathrm{NO}_{3}$, nitrite plus nitrate; diss, dissolved; amm + org, ammonia plus organic; ortho, orthophosphate. Unit: $\mathrm{mg} / \mathrm{L}$, milligrams per liter; $\mu \mathrm{g} / \mathrm{L}$, micrograms per liter. Regression equation: qlog, base 10 logarithm of streamflow, in cubic feet per second; sc, specific conductance, in microsiemens per centimeter at $25^{\circ} \mathrm{C} ; \mathrm{pH}$, in standard $\mathrm{pH}$ units; sea ${ }^{l}$, seasonality variable; sclog, base 10 logarithm of specific conductance, in microsiemens per centimeter at $25^{\circ} \mathrm{C}$; q, streamflow, in cubic feet per second; temp, water temperature, in ${ }^{\circ} \mathrm{C}$; DOlog, base 10 logarithm of dissolved-oxygen concentration, in $\mathrm{mg} / \mathrm{L}$; $\mathrm{DO}$, dissolved-oxygen concentration, in $\mathrm{mg} / \mathrm{L}$. Adj $\mathrm{R}^{2}$, adjusted coefficient of determination (Ott, 1993). Method: MLR, multiple linear regression; KTR, Kendall-Theil robust line. --, not applicable]

\begin{tabular}{|c|c|c|c|c|}
\hline Analyte & Unit & Regression equation & Adj $R^{2}$ & Method \\
\hline $\begin{array}{l}\text { Solids, residue at } 180^{\circ} \mathrm{C} \\
\text { (dissolved solids) }\end{array}$ & $\mathrm{mg} / \mathrm{L}$ & $419.34-14.592 \mathrm{qlog}+0.733 \mathrm{sc}-51.598 \mathrm{pH}+9.575 \mathrm{sea}$ & 0.994 & MLR \\
\hline Calcium & $\mathrm{mg} / \mathrm{L}$ & $44.5+0.0870 \mathrm{sc}-4.950 \mathrm{pH}$ & .965 & MLR \\
\hline Magnesium & $\mathrm{mg} / \mathrm{L}$ & $10^{(-1.116+0.859 \mathrm{sclog}-0.033 \mathrm{pH})}$ & .985 & MLR \\
\hline Sodium & $\mathrm{mg} / \mathrm{L}$ & $-2.62-0.0019 q+0.095 s c$ & .988 & MLR \\
\hline Potassium & $\mathrm{mg} / \mathrm{L}$ & $2.23-0.00008 q+0.0036 s c$ & .876 & MLR \\
\hline Bicarbonate, as $\mathrm{HCO}_{3}$ & $\mathrm{mg} / \mathrm{L}$ & $10^{(-1.050-0.0008 \mathrm{sc}+1.372 \mathrm{sclog}-0.005 \text { temp })}$ & .752 & MLR \\
\hline Sulfate, as $\mathrm{SO}_{4}$ & $\mathrm{mg} / \mathrm{L}$ & $774.97+0.627 \mathrm{sc}-334.97 \mathrm{sclog}-103.41 \mathrm{DOlog}$ & .988 & MLR \\
\hline Chloride & $\mathrm{mg} / \mathrm{L}$ & $10^{(-1.684-0.083 \mathrm{qlog}+1.265 \mathrm{sclog}-0.015 \text { temp }+0.066 \mathrm{sea})}$ & .873 & MLR \\
\hline Fluoride & $\mathrm{mg} / \mathrm{L}$ & $10^{(-3.731-0.00003 q-0.0007 s c+1.421 \mathrm{sclog})}$ & .724 & MLR \\
\hline Silica, as $\mathrm{SiO}_{2}$ & $\mathrm{mg} / \mathrm{L}$ & $10^{(-0.606-0.0006 \mathrm{sc}+0.766 \mathrm{sclog}+0.018 \mathrm{DO})}$ & .707 & MLR \\
\hline $\begin{array}{l}\text { Nitrogen, } \mathrm{NO}_{2}+\mathrm{NO}_{3} \text {, } \\
\text { diss, as } \mathrm{N} \\
\text { Nitrogen, amm + org, }\end{array}$ & $\mathrm{mg} / \mathrm{L}$ & $-4.725+0.217$ qlog +1.814 sclog -0.281 sea & .841 & MLR \\
\hline total, as $\mathrm{N}$ & $\mathrm{mg} / \mathrm{L}$ & $-1.328+0.004 s c$ & -- & KTR \\
\hline Phosphorus, total, as $\mathrm{P}$ & $\mathrm{mg} / \mathrm{L}$ & $10^{(-6.389+2.237 \mathrm{sclog})}$ & .382 & MLR \\
\hline $\begin{array}{l}\text { Phosphorus, diss, as } \mathrm{P} \\
\text { Phosphorus, ortho, }\end{array}$ & $\mathrm{mg} / \mathrm{L}$ & $10^{(-8.080+0.00009} q-0.518 \mathrm{DO}+12.333$ DOlog $\left.-0.190 \mathrm{sea}\right)$ & .685 & MLR \\
\hline diss, as $\mathrm{P}$ & $\mathrm{mg} / \mathrm{L}$ & $-0.454+0.628$ DOlog & .727 & MLR \\
\hline Iron, diss & $\mu \mathrm{g} / \mathrm{L}$ & $10^{(7.676-2.488 \mathrm{sclog})}$ & -- & KTR \\
\hline
\end{tabular}

${ }^{1} \operatorname{sea}=\sin (T)+\cos (T)$ where $T$ equals the time, in months, from December 1, 1992, times 0.5236 . 


\section{Site 16 - Rio Grande below Leasburg Dam, near Las Cruces, N. Mex.}

Site 16 is an integrator site on the main stem approximately $1.5 \mathrm{mi}$ southeast of Radium Springs, New Mexico. The streamflow-gaging station for this site is operated by the Elephant Butte Irrigation District. The gage is located approximately $1.5 \mathrm{mi}$ downstream from Leasburg Dam, a low head diversion dam used to divert water from the Rio Grande to irrigation-supply canals for the Mesilla Valley. Lowflow samples were collected by wading, and high-flow samples were collected from a cableway at the gaging station.

Major land use in the 4,260- $\mathrm{mi}^{2}$ contributing drainage basin between sites 15 and 16 is rangeland (U.S. Geological Survey, 1986); however, water quality at site 16 probably is more affected by Elephant Butte and Caballo Reservoirs, which store irrigation water between sites 15 and 16, and the small area of intense agricultural activity in the Rincon Valley upstream from this site (Scott Anderholm, U.S. Geological Survey, written commun., 1996). Major surficial deposits and bedrock types are Tertiary volcanic rock and Quaternary unconsolidated gravel, sand, and silt (Dane and Bachman, 1965).

The streamflow at this station is almost completely controlled by releases from Caballo Reservoir. Releases begin in January or February and end in September or October. High flows are in late spring and early summer. During the period when water is not released from Caballo Reservoir, streamflow at site 16 is mainly ground-water inflow to the main stem. The annual mean discharge at site 16 for WY's 1938 to 1995 was $693 \mathrm{ft}^{3} / \mathrm{s}$. The annual mean discharge for WY 1993 was $859 \mathrm{ft}^{3} / \mathrm{s}$ (Cruz and others, 1994); for WY 1994 was $883 \mathrm{ft}^{3} / \mathrm{s}$ (Borland and Ong, 1995); and for WY 1995 was $1,163 \mathrm{ft}^{3} / \mathrm{s}$ (Ortiz and Lange, 1996).

The water sampled at site 16 for the most part was a well-oxygenated, calcium sodium sulfate bicarbonate chloride type. Of the anions, sulfate had the largest percentage of total anion milliequivalents per liter during low flow and bicarbonate had the largest during high flows. The median specificconductance value was 740 , the median $\mathrm{pH}$ value was 8.3, and the median DO percent of saturation was 98 . DS and most major constituents were in the high group; silica was in the low group. Silica appeared to have been effectively removed from the water in the two reservoirs, probably due to biological activity. Streamflow showed moderate negative correlations with specific conductance (-0.62), DS (-0.58), and most major constituents $(-0.32$ to -0.69$)$; chloride $(-0.70)$ showed a strong negative correlation with streamflow; and silica $(-0.18)$ showed no correlation with streamflow. The largest concentrations of DS and most major constituents were during low flow.

Most nutrients were in the middle group; dissolved phosphorus was in the low group. The median concentrations of $\mathrm{NO}_{2}$ and orthophosphate were below their respective MDL's. The two reservoirs appear to have effectively removed most of the nutrient load from the Rio Grande through sediment trapping and biological activities. During high flow, groundwater inflow and irrigation-drain discharges in the Rincon Valley did not measurably affect nutrient concentrations in the main stem Rio Grande. During low flow, because of the difference in magnitude of flows in the main stem and irrigation drains, groundwater inflow to the main stem, derived from the irrigated fields, appears to be the major source of nutrients in the main stem at site 16 (Scott Anderholm, U.S. Geological Survey, oral commun., 1996).

Dissolved iron and dissolved manganese were in the low group. Site 16 was one of two sites that had the smallest median dissolved-iron concentration.

Summary statistics for the field-property and chemicalanalyte data for site 16 are presented in table 35 .

Regression equations that relate selected water-quality data to selected field properties and time are presented in table 36.

\section{Site 17 - Rio Grande at EI Paso, Tex.}

Site 17 is an integrator site on the main stem approximately $1 \mathrm{mi}$ southeast of Sunland Park, New Mexico. The streamflow-gaging station for this site is operated by the International Boundary and Water Commission and is located at the Courchesne Bridge on Texas State Highway 273. Low-flow samples were collected by wading upstream from the bridge, and high-flow samples were collected on the upstream side of the bridge or by boat.

The major land-use type in the $1,080-\mathrm{mi}^{2}$ contributing drainage area between sites 16 and 17 is rangeland (U.S. Geological Survey, 1986); water quality at site 17 , however, is more affected by the areas of agricultural and urban land use in the Mesilla Valley just upstream from this site (Healy, 1996). Major surficial deposits in this drainage area are Quaternary unconsolidated gravel, sand, and silt (Dane and Bachman, 1965). 


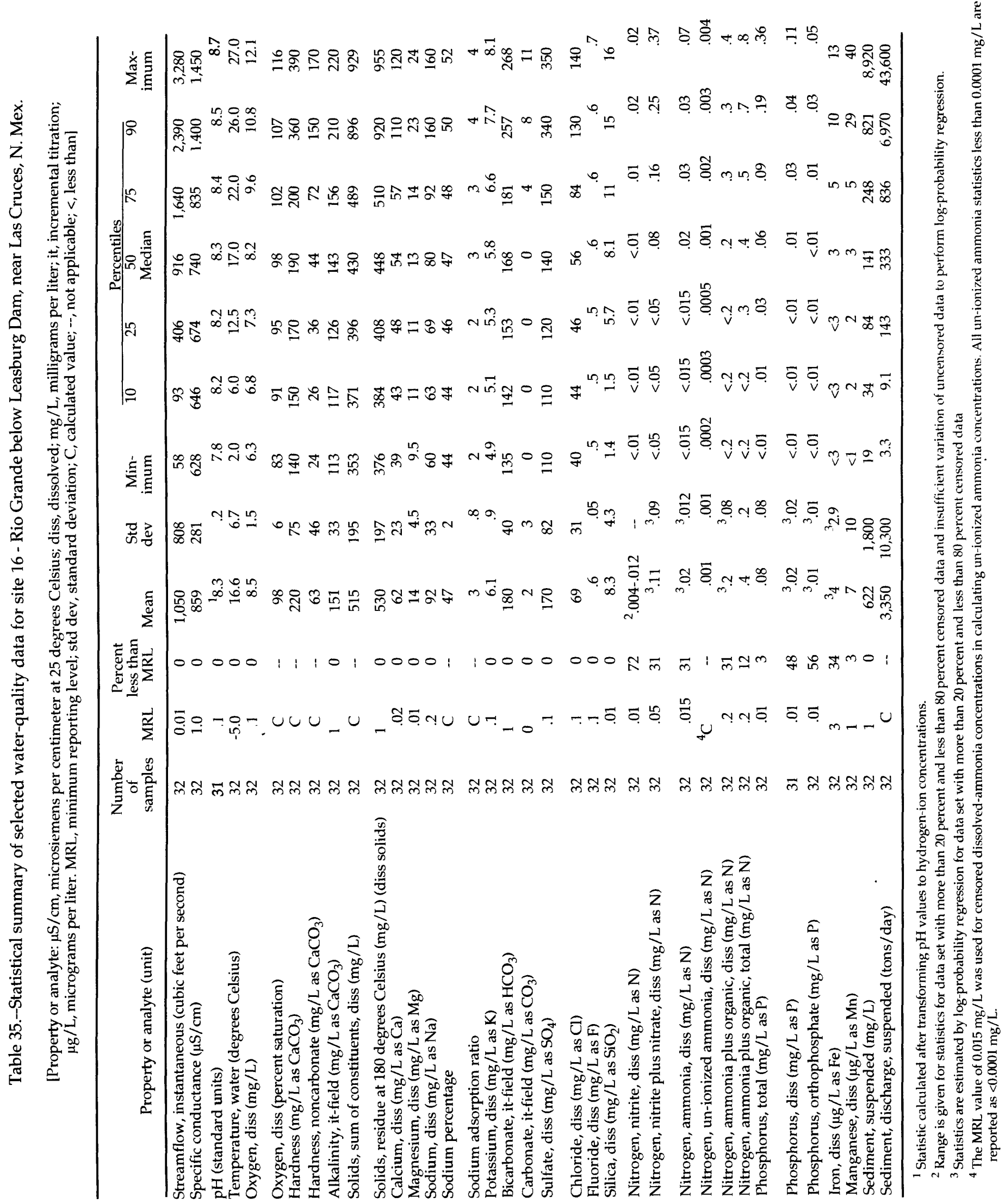


Table 36.--Regression equations for selected water-quality analytes with selected field properties and time for site 16 - Rio Grande below Leasburg Dam, near Las Cruces, N. Mex.

[Analyte: ${ }^{\circ} \mathrm{C}$, degrees Celsius; amm + org, ammonia plus organic; diss, dissolved. Unit: $\mathrm{mg} / \mathrm{L}$, milligrams per liter; $\mu \mathrm{g} / \mathrm{L}$, micrograms per liter. Regression equation: sc, specific conductance, in microsiemens per centimeter at $25^{\circ} \mathrm{C}$; q, streamflow, in cubic feet per second; qlog, base 10 logarithm of streamflow, in cubic feet per second; sclog, base 10 logarithm of specific conductance, in microsiemens per centimeter at

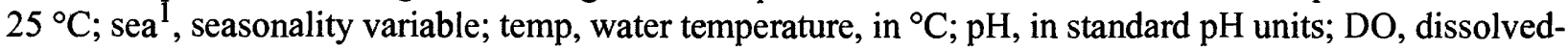
oxygen concentration, in $\mathrm{mg} / \mathrm{L}$; DOlog, base 10 logarithm of dissolved-oxygen concentration, in $\mathrm{mg} / \mathrm{L}$. Adj $R^{2}$, adjusted coefficient of determination (Ott, 1993). Method: MLR, multiple linear regression; KTR, Kendall-Theil robust line. --, not applicable]

\begin{tabular}{|c|c|c|c|c|}
\hline Analyte & Unit & Regression equation & Adj $R^{2}$ & Method \\
\hline $\begin{array}{l}\text { Solids, residue at } 180^{\circ} \mathrm{C} \\
\text { (dissolved solids) }\end{array}$ & $\mathrm{mg} / \mathrm{L}$ & $3,241.7+1.288 \mathrm{sc}-1,430.26 \mathrm{sclog}+339.4$ DOlog +2.319 temp & 0.988 & MLR \\
\hline Calcium & $\mathrm{mg} / \mathrm{L}$ & $-258.33+0.008 q-32.389 q \log +138.24$ sclog +4.887 sea & .977 & MLR \\
\hline Magnesium & $\mathrm{mg} / \mathrm{L}$ & $-66.50+0.0007 q-3.222 q \log +30.314$ sclog +0.057 temp & .984 & MLR \\
\hline Sodium & $\mathrm{mg} / \mathrm{L}$ & $-449.13+0.004 q-22.969 q \log +206.414$ sclog & .990 & MLR \\
\hline Potassium & $\mathrm{mg} / \mathrm{L}$ & $-16.946+7.794$ sclog +0.019 temp & .852 & MLR \\
\hline Bicarbonate, as $\mathrm{HCO}_{3}$ & $\mathrm{mg} / \mathrm{L}$ & $44.274+0.157 \mathrm{sc}+7.555 \mathrm{sea}$ & .902 & MLR \\
\hline Sulfate, as $\mathrm{SO}_{4}$ & $\mathrm{mg} / \mathrm{L}$ & $2,024.6-24.20 \mathrm{qlog}+0.611 \mathrm{sc}-828.22 \mathrm{sclog}+8.136 \mathrm{DO}$ & .986 & MLR \\
\hline Chloride & $\mathrm{mg} / \mathrm{L}$ & $\begin{array}{c}-600.3878+20.5163 \mathrm{qlog}+233.1403 \mathrm{sclog}-13.0577 \mathrm{pH} \\
+4.933 \mathrm{DO}-7.1014 \mathrm{sea}\end{array}$ & 977 & MLR \\
\hline Fluoride & $\mathrm{mg} / \mathrm{L}$ & $10^{(-2.395-0.191 \mathrm{DO}+4.086 \mathrm{DOlog})}$ & .551 & MLR \\
\hline Silica, as $\mathrm{SiO}_{2}$ & $\mathrm{mg} / \mathrm{L}$ & $-7.99+0.0028 q+0.016 s c+0.241$ temp -2.880 sea & .627 & MLR \\
\hline $\begin{array}{l}\text { Nitrogen, amm +org, } \\
\text { total, as } \mathrm{N}\end{array}$ & $\mathrm{mg} / \mathrm{L}$ & $10^{(-0.026-0.0006 \mathrm{sc})}$ & -- & KTR \\
\hline Phosphorus, total, as $\mathbf{P}$ & $\mathrm{mg} / \mathrm{L}$ & $10^{(14.056-2.474 \mathrm{sclog}-7.636 \text { DOlog - } 0.062 \text { temp - } 0.235 \mathrm{sea})}$ & .532 & MLR \\
\hline Manganese, diss & $\mu \mathrm{g} / \mathrm{L}$ & $10^{(16.03+0.004 \mathrm{sc}-6.513 \text { sclog }-0.298 \mathrm{pH}+2.766 \mathrm{DOlog}+0.106 \mathrm{sea})}$ & .879 & MLR \\
\hline
\end{tabular}

${ }^{1}$ sea $=\sin (T)+\cos (T)$ where $T$ equals the time, in months, from December I, 1992, times 0.5236. 
Streamflow at site 17 is controlled by releases from Caballo Reservoir and has the same general pattern of low flows and high flows as site 16. During low flows, however, streamflow at site 17 generally is higher than that at site 16 , whereas during high flows streamflow at site 17 generally is lower than that at site 16. Because site 17 is located near the discharge point for an alluvial basin, the gain in streamflow during low flow is probably the result of ground water discharging to the Rio Grande (Ellis and others, 1993). At other times, the loss of water to evapotranspiration and to seepage of irrigation water to the ground-water system exceeds this gain. The annual mean discharge at site 17 for WY's 1938 to 1995 was $557 \mathrm{ft}^{3} / \mathrm{s}$. The annual mean discharge for WY 1993 was $714 \mathrm{ft}^{3} / \mathrm{s}$ (Cruz and others, 1994); for WY 1994 was $670 \mathrm{ft}^{3} / \mathrm{s}$ (Borland and Ong, 1995); and for WY 1995 was $974 \mathrm{ft}^{3} / \mathrm{s}$ (Ortiz and Lange, 1996).

The water sampled at site 17 for the most part was a well-oxygenated. sodium sulfate bicarbonate chloride type. The larger concentrations of DS and major constituents were detected during low flow. Of the anions, sulfate had the largest percentage of total milliequivalents per liter and bicarbonate had the second largest. During low flow, however, chloride exceeded bicarbonate as the anion with the second largest percentage of total anion milliequivalents per liter. This may be due to the larger percentage of ground water and WWTP effluent in the streamflow during this period. The median specific-conductance value was 1,070 , the median $\mathrm{pH}$ value was 8.3 , and the median DO percent of saturation was 95 . DS and most major constituents were in the high group; silica was in the low group. The median chloride concentration was the largest detected at any basic-fixed site. Streamflow showed strong negative correlations with specific conductance $(-0.80)$ and DS $(-0.77)$ and moderate to strong negative correlations with the major constituents $(-0.56$ to -0.86$)$ except silica $(-0.27)$, which showed no correlation to streamflow.

Most nutrients were in the high group; total ammonia plus organic nitrogen, dissolved phosphorus, and orthophosphate were in the middle group. All median nutrient concentrations increased between sites 16 and 17 due mainly to a combination of agricultural and urban discharges in the Mesilla Valley (Healy, 1996).

Dissolved iron and dissolved manganese were in the low group. Site 17 was one of two sites that had the smallest median dissolved-iron concentration.
Summary statistics for the field-property and chemical-analyte data for site 17 are presented in table 37. Regression equations that relate selected waterquality data to selected field properties and time are presented in table 38 .

\section{WATER-QUALITY DATA FOR SUPPLEMENTAL SAMPLES}

The supplemental trace-element (table 3) and pesticide (table 4) data analyzed in this section were collected mainly during monthly sampling in addition to collection of the regular monthly samples. Dissolved organic carbon (DOC) (table 3 ) and suspended organic carbon (table 3 ) also were collected as part of monthly sampling during WY 1993; however, they were collected at basic-fixed sites as additions to regular sampling or as part of a synoptic study during WY's 1994 and 1995. Total organic carbon (TOC) (table 3) samples were collected at the sites in conjunction with total recoverable trace-element sampling or as part of a cooperative program.

\section{Trace Elements and Organic Carbon}

Trace elements were collected as part of basicfixed-site sampling during only the spring and summer of 1995. A single sample for total recoverable trace elements and a single sample for dissolved trace elements were collected at each site. In addition. trace elements were collected at basic-fixed sites as part of NASQAN, cooperative programs, and RIOG synoptic studies.

Table 39 summarizes trace-element data for these four sources. Data in this table are only for samples collected using NAWQA protocols and analyzed at the NWQL. Table 39 presents for each trace element the number of samples; minimum, median, and maximum concentrations; the site at which the maximum concentration was detected; the MRL; and the number of samples with censored data for their respective MRL's. Some trace elements have multiple MRL's because of different analytical procedures used for NAWQA samples and NASQAN and cooperator samples or because of qualityassurance testing at the time of analysis. Only the MRL's at which data were censored are presented in table 39. 


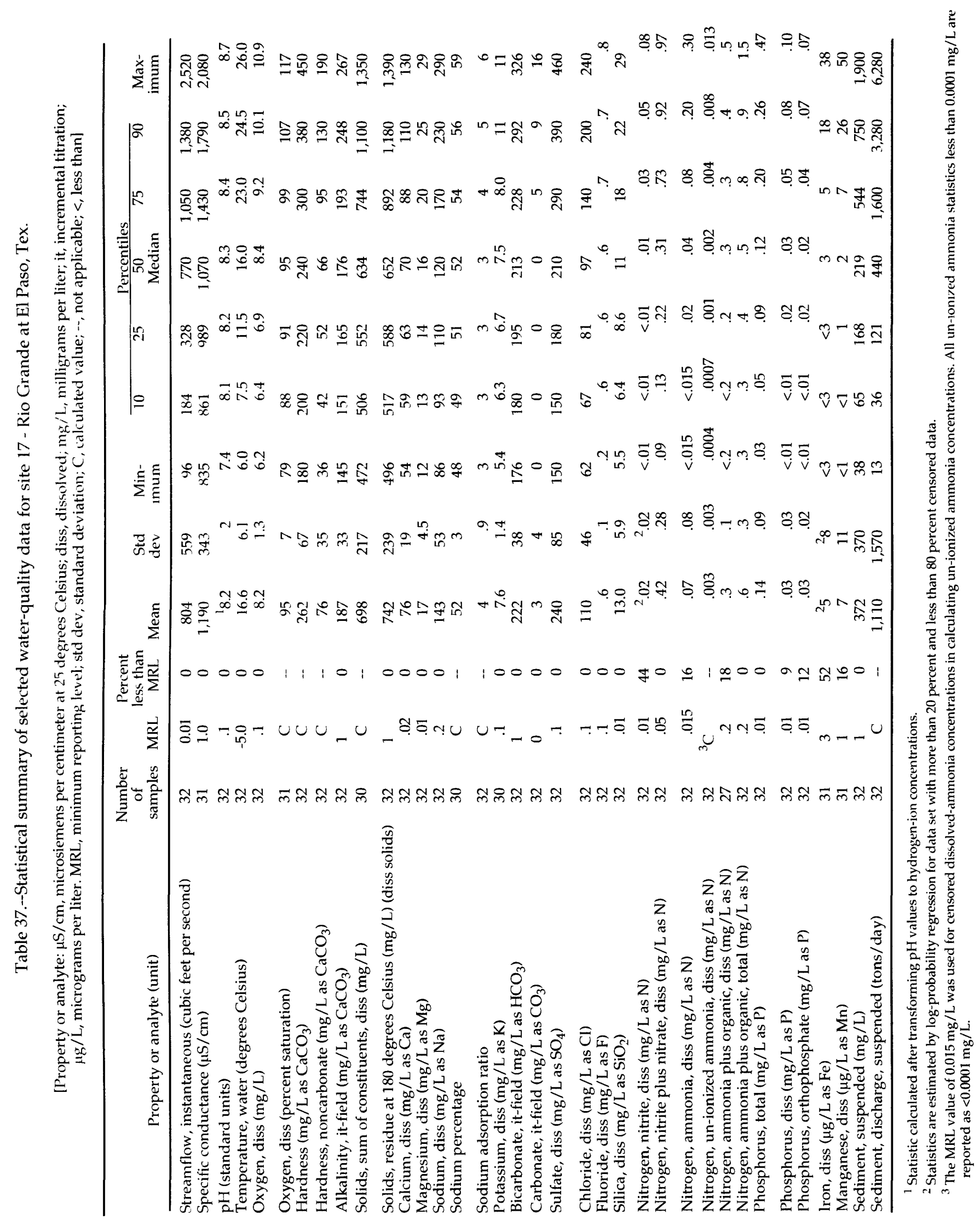


Table 38.--Regression equations for selected water-quality analytes with selected field properties and time for site 17 - Rio Grande at El Paso, Tex.

[Analyte: ${ }^{\circ} \mathrm{C}$, degrees Celsius; $\mathrm{NO}_{2}+\mathrm{NO}_{3}$, nitrite plus nitrate; diss, dissolved; amm, ammonia; amm + org, ammonia plus organic; ortho, orthophosphate. Unit: $\mathrm{mg} / \mathrm{L}$, milligrams per liter; $\mu \mathrm{g} / \mathrm{L}$, micrograms per liter.

Regression equation: sc, specific conductance, in microsiemens per centimeter at $25^{\circ} \mathrm{C}$; sclog, base 10 logarithm of specific conductance, in microsiemens per centimeter at $25^{\circ} \mathrm{C}$; temp, water temperature, in

${ }^{\circ} \mathrm{C}$; qlog, base 10 logarithm of streamflow, in cubic feet per second; DOlog, base 10 logarithm of dissolved-oxygen concentration, in $\mathrm{mg} / \mathrm{L}$; DO, dissolved-oxygen concentration, in $\mathrm{mg} / \mathrm{L}$; sea ${ }^{\mathrm{l}}$. seasonality variable; q, streamflow, in cubic feet per second. Adj $R^{2}$, adjusted coefficient of determination (Ott. 1993). Method: MLR, multiple linear regression; KTR, Kendall-Theil robust line. --, not applicable]

\begin{tabular}{|c|c|c|c|c|}
\hline Analyte & Unit & Regression equation & Adj $R^{2}$ & Method \\
\hline $\begin{array}{l}\text { Solids, residue at } 180^{\circ} \mathrm{C} \\
\text { (dissolved solids) }\end{array}$ & $\mathrm{mg} / \mathrm{L}$ & $-80.2+0.695 \mathrm{sc}$ & 0.980 & MLR \\
\hline Calcium & $\mathrm{mg} / \mathrm{L}$ & $3.72+0.059 \mathrm{sc}+0.221$ temp & .971 & MLR \\
\hline Magnesium & $\mathrm{mg} / \mathrm{L}$ & $-43.19+0.00077 \mathrm{sc}+16.879 \mathrm{sclog}$ & .972 & MLR \\
\hline Sodium & $\mathrm{mg} / \mathrm{L}$ & $832.06-42.028 \mathrm{qlog}+0.202 \mathrm{sc}-248.22 \mathrm{sclog}-57.23$ DOlog & .989 & MLR \\
\hline Potassium & $\mathrm{mg} / \mathrm{L}$ & $2.91+0.0041 \mathrm{sc}$ & .864 & MLR \\
\hline Bicarbonate, as $\mathrm{HCO}_{3}$ & $\mathrm{mg} / \mathrm{L}$ & $10^{(-0.664+0.781 \mathrm{sclog}-0.086 \mathrm{DO}+1.451 \mathrm{DO} \log +0.014 \mathrm{sea})}$ & .887 & MLR \\
\hline Sulfate, as $\mathrm{SO}_{4}$ & $\mathrm{mg} / \mathrm{L}$ & $-55.6+0.249 \mathrm{sc}$ & .981 & MLR \\
\hline Chloride & $\mathrm{mg} / \mathrm{L}$ & $-24.557+0.117 \mathrm{sc}-6.438$ sea & .970 & MLR \\
\hline Fluoride & $\mathrm{mg} / \mathrm{L}$ & $-0.568+0.398$ sclog & .420 & MLR \\
\hline Silica & $\mathrm{mg} / \mathrm{L}$ & $\begin{array}{r}133.23+6.775 \mathrm{qlog}+0.036 \mathrm{sc}-61.262 \mathrm{sclog} \\
+0.396 \text { temp }-4.315 \text { sea }\end{array}$ & .913 & MLR \\
\hline $\begin{array}{l}\text { Nitrogen, } \mathrm{NO}_{2}+\mathrm{NO}_{3}, \\
\text { diss, as } \mathrm{N}\end{array}$ & $\mathrm{mg} / \mathrm{L}$ & $2.378-0.751 q \log +0.0002 q-0.096$ sea & .856 & MLR \\
\hline Nitrogen, amm, diss, as & $\mathrm{Jmg} / \mathrm{L}$ & $0.396-0.123$ qlog & -- & KTR \\
\hline $\begin{array}{l}\text { Nitrogen, amm + org, } \\
\text { diss, as } \mathrm{N} \\
\text { Nitrogen amm + org }\end{array}$ & $\mathrm{mg} / \mathrm{L}$ & $-1.501+0.594$ sclog & -- & KTR \\
\hline $\begin{array}{l}\text { Nitrogen, amm + org, } \\
\text { totaI, as } \mathrm{N}\end{array}$ & $\mathrm{mg} / \mathrm{L}$ & $33.629-0.976 \mathrm{q} \log +0.002 \mathrm{sc}-10.783 \mathrm{sclog}-0.132$ sea & .294 & MLR \\
\hline Phosphorus, total, as $\mathrm{P}$ & $\mathrm{mg} / \mathrm{L}$ & $10^{(47.64-1.325 \mathrm{qlog}+0.003 \mathrm{sc}-14.527 \mathrm{sclog}-4.364 \text { DOlog - } 0.034 \text { temp })}$ & .360 & MLR \\
\hline Phosphorus, diss, as $\mathrm{P}$ & $\mathrm{mg} / \mathrm{L}$ & $-0.229+0.085 \mathrm{sclog}$ & - & KTR \\
\hline $\begin{array}{l}\text { Phosphorus, ortho, } \\
\text { diss, as } \mathrm{P} \\
\text { Manganese, diss }\end{array}$ & $\begin{array}{l}\mathrm{mg} / \mathrm{L} \\
\mu \mathrm{g} / \mathrm{L}\end{array}$ & $\begin{array}{l}-0.104+0.041 \mathrm{sclog} \\
-13.588+0.015 \mathrm{sc}\end{array}$ & -- & $\begin{array}{l}\text { KTR } \\
\text { KTR }\end{array}$ \\
\hline
\end{tabular}

$\mathrm{I}_{\text {sea }}=\sin (T)+\cos (\mathrm{T})$ where $T$ equals the time, in months, from December 1, 1992, times 0.5236 . 
[Some analytes have multiple minimum reporting levels (MRL's) because of different analytical procedures used or because of quality-assurance testing at the time of analysis. Only the MRL's at which data were censored are presented in this table. Analyte: ww rec, whole water recoverable--because of incomplete digestion, determination represents a value less than the total amount (less than 95 percent) of the analyte present in the dissolved and suspended phases (Timme, 1995); dissolved, analytes in a representative water sample passed through a 0.45 -micron filter membrane for inorganic analysis or a 0.7 -micron glass-fiber filter for organic analysis (Timme, 1995). $\mu \mathrm{g} / \mathrm{L}$. micrograms per liter; --, not applicable; <, less than]

\begin{tabular}{|c|c|c|c|c|c|c|c|}
\hline \multirow[b]{3}{*}{ Analyte } & \multirow{3}{*}{$\begin{array}{c}\text { Number } \\
\text { of } \\
\text { samples }\end{array}$} & \multirow{2}{*}{\multicolumn{3}{|c|}{ Concentration }} & \multirow{3}{*}{$\begin{array}{c}\text { Site(s) of } \\
\text { maximum } \\
\text { concentration } \\
\text { (table 1) }\end{array}$} & \multicolumn{2}{|c|}{ Censored data } \\
\hline & & & & & & \multirow[b]{2}{*}{$\begin{array}{c}\text { MRL } \\
(\mu \mathrm{g} / \mathrm{L})\end{array}$} & \multirow{2}{*}{$\begin{array}{l}\text { Number } \\
\text { less than } \\
\text { MRL }\end{array}$} \\
\hline & & $\begin{array}{c}\text { Minimum } \\
(\mu \mathrm{g} / \mathrm{L})\end{array}$ & $\begin{array}{c}\text { Median } \\
(\mu \mathrm{g} / \mathrm{L})\end{array}$ & $\begin{array}{l}\text { Maximum } \\
(\mu \mathrm{g} / \mathrm{L})\end{array}$ & & & \\
\hline Aluminum. ww rec & 18 & 190 & 1.850 & 210,000 & 13 & -- & -- \\
\hline \multirow[t]{2}{*}{ Alumınum. dissolved } & 50 & $<1$ & 11.5 & 430 & 15 & 1 & 1 \\
\hline & & & & & & 10 & 17 \\
\hline Antimony, ww rec & 17 & $<1$ & $<1$ & 12 & 13 & 1 & 15 \\
\hline Antimony, dissolved & 19 & $<1$ & $<1$ & $<1$ & -- & 1 & 19 \\
\hline Arsenic, ww rec & 37 & $<1$ & 2 & 6 & 12.14 & 1 & 4 \\
\hline Arsenic, dissolved & 41 & $<1$ & 2 & 5 & 11,12 & 1 & 6 \\
\hline Barium, ww rec & 17 & $<100$ & $<100$ & 1,900 & 13 & 100 & 10 \\
\hline Barium, dissolved & 49 & 14 & 56 & 101 & 16 & -- & -- \\
\hline Beryllium, ww rec & 17 & $<10$ & $<10$ & 30 & 13 & 10 & 16 \\
\hline Beryllium, dissolved & 19 & $<1$ & $<1$ & $<1$ & -- & 1 & 19 \\
\hline Boron, ww rec & 17 & $<10$ & 40 & 200 & 13 & 10 & 5 \\
\hline Boron, dissolved & 46 & $<10$ & 50 & 450 & 12 & 10 & 8 \\
\hline Cadmium, ww rec & 36 & $<1$ & $<1$ & 8 & 13 & 1 & 32 \\
\hline Cadmium. dissolved & 41 & $<1$ & $<1$ & $<1$ & -- & 1 & 41 \\
\hline Chromium, ww rec & 36 & $<1$ & 1.6 & 160 & 13 & 1 & 12 \\
\hline Chromium, dissolved & 41 & $<1$ & $<1$ & 7 & 17 & 1 & 35 \\
\hline Cobalt, ww rec & 17 & $<1$ & 1 & 270 & 13 & 1 & 6 \\
\hline \multirow[t]{2}{*}{ Cobalt. dissolved } & 51 & $<1$ & $<3$ & 3 & 12 & 1 & 19 \\
\hline & & & & & & 3 & 31 \\
\hline Copper, ww rec & 36 & $<1$ & 3.5 & 880 & 13 & 1 & 5 \\
\hline Copper. dissolved & 41 & $<1$ & 2 & 6 & 11 & 1 & 10 \\
\hline Cyanide. ww rec & 23 & $<10$ & $<10$ & 40 & 9 & 10 & 22 \\
\hline Cyanide dissolved & 2 & $<10$ & - & $<10$ & -- & 10 & 2 \\
\hline Iron, ww rec & 17 & 220 & 1,900 & 220,000 & 13 & -- & -- \\
\hline Lead, ww rec & 36 & $<1$ & 3 & 500 & 13 & 1 & 6 \\
\hline Lead. dissolved & 41 & $<1$ & $<1$ & 3 & 11 & 1 & 37 \\
\hline Lithium, ww rec & 17 & $<10$ & 20 & 800 & 13 & 10 & 6 \\
\hline Lithium, dissolved & 45 & $<4$ & 35 & 220 & 17 & 4 & 4 \\
\hline Manganese, ww rec & 17 & 10 & 120 & 13,000 & 13 & -- & -- \\
\hline Mercury, ww rec & 35 & $<.1$ & $<.1$ & 3.3 & 13 & .1 & 31 \\
\hline Mercury, dissolved & 37 & $<.1$ & $<.1$ & $<.1$ & -- & .1 & 37 \\
\hline Molybdenum, ww rec & 17 & $<1$ & 1.8 & 6.7 & 17 & 1 & 8 \\
\hline \multirow{2}{*}{ Molybdenum, dissolved } & 59 & $<1$ & 10 & 20 & 15,17 & 1 & 4 \\
\hline & & & & & & 10 & 17 \\
\hline
\end{tabular}


Table 39.--Summary statistics for supplemental trace-element analytes--Concluded

\begin{tabular}{|c|c|c|c|c|c|c|c|}
\hline \multirow[b]{3}{*}{ Analyte } & \multirow{3}{*}{$\begin{array}{c}\text { Number } \\
\text { of } \\
\text { samples }\end{array}$} & \multirow{2}{*}{\multicolumn{3}{|c|}{ Concentration }} & \multirow{3}{*}{$\begin{array}{l}\text { Site(s) of } \\
\text { maximum } \\
\text { concentration } \\
(\text { table } 1)\end{array}$} & \multicolumn{2}{|c|}{ Censored data } \\
\hline & & & & & & \multirow[b]{2}{*}{$\begin{array}{c}\text { MRL } \\
(\mu \mathrm{g} / \mathrm{L})\end{array}$} & \multirow{2}{*}{$\begin{array}{l}\text { Number } \\
\text { less than } \\
\text { MRL }\end{array}$} \\
\hline & & $\begin{array}{c}\text { Minimum } \\
(\mu \mathrm{g} / \mathrm{L})\end{array}$ & $\begin{array}{c}\text { Median } \\
(\mu \mathrm{g} / \mathrm{L})\end{array}$ & $\begin{array}{c}\text { Maximum } \\
(\mu \mathrm{g} / \mathrm{L})\end{array}$ & & & \\
\hline Nickel, ww rec & 17 & $<1$ & 3 & 380 & 13 & 1 & 5 \\
\hline Nickel, dissolved & 50 & $<1$ & 1 & 9 & 13 & 1 & 23 \\
\hline Selenium, ww rec & 36 & $<1$ & $<1$ & 38 & 13 & $\begin{array}{r}1 \\
25\end{array}$ & 31 \\
\hline Selenium, dissolved & 70 & $<1$ & $<1$ & 3 & 13 & $\begin{array}{l}1 \\
2\end{array}$ & $\begin{array}{r}61 \\
3\end{array}$ \\
\hline Silver, ww rec & 18 & $<1$ & $<1$ & 5 & 13 & 1 & 17 \\
\hline Silver, dissolved & 51 & $<1$ & $<1$ & $<1$ & -- & 1 & 51 \\
\hline Strontium, ww rec & 17 & 40 & 250 & 7,500 & 13 & -- & -- \\
\hline Strontium, dissolved & 60 & 43 & 320 & 2,100 & 13 & -- & -- \\
\hline Uranium, dissolved & 38 & $<1$ & 2.4 & 13 & 13 & 1 & 8 \\
\hline Vanadium. dissolved & 46 & $<6$ & $<6$ & 9 & 5,7 & 6 & 40 \\
\hline Zinc. ww rec & 36 & $<10$ & 15 & 1,300 & 13 & 10) & 9 \\
\hline Zinc. dissolved & 41 & $<1$ & $<10$ & 51 & 11 & 1 & 1 \\
\hline & & & & & & 10 & 19 \\
\hline
\end{tabular}


Because of the small number of samples, a detailed examination of the spatial variation of trace elements at the basic-fixed sites is not warranted. However, some general observations can be made. The maximum concentrations of most total recoverable trace elements were detected at site 13. This was due to the large suspended-sediment concentrations at this site; trace-element concentrations on a gram-to-gram basis in the suspended sediment at this site are similar to comparative concentrations at other basic-fixed sites. Concentrations of dissolved antimony, beryllium. cadmium, mercury, and silver were smaller than their respective MRL's in all samples. Concentrations of dissolved chromium, cobalt, lead, selenium, and vanadium were smaller than their respective MRL's in more than 80 percent of the samples; concentrations of these trace elements detected in the remaining samples were within the range of natural waters (Hem, 1985). Concentrations of dissolved arsenic, copper, and nickel were near or smaller than their respective MRL's in more than 50 percent of the samples. Concentrations of dissolved barium, boron, lithium, molybdenum, strontium, and uranium increased in a downstream direction, although the largest concentrations of boron, strontium, and uranium were detected at site 13 . The two relatively large dissolved-aluminum concentrations at sites 9 and 15 probably were due to particulate or colloids that were less than 0.45 micron, whereas the relatively large dissolved-zinc concentrations at sites 1 and 11 may have had anthropogenic sources.

Table 40 summarizes organic carbon sampling at the basic-fixed sites. The maximum TOC concentration was detected at site 13 . The maximum DOC concentrations at sites $7,8,9,12$, and 15 are significantly larger than the maximum DOC concentrations detected at the other basic-fixed sites or any other DOC concentration from those five sites; all are from the June 1993 sampling.

\section{Pesticides}

A total of 58 samples from nine basic-fixed sites were analyzed for dissolved-pesticide concentrations. Forty-four of the samples were collected during monthly sampling in the spring and summer of 1995 , 13 samples were collected during the Mesilla Valley synoptic study, and 1 sample was collected as part of the survey sample at site 12 in August 1994. All 58 samples were analyzed by the $\mathrm{C}-18$ solid-phase extraction method (Zaugg and others, 1995). The 13 samples collected during the Mesilla Valley synoptic and the single survey sample also were analyzed by the Carbopak-B solid-phase extraction method (Werner and others, 1996). Table 41 lists the sampling sites, number of samples, time period of samples, and the study for which the samples were collected.

There was a total of 152 detections of 17 pesticides from 3,278 analyses of 88 pesticide analytes (table 3). Simazine was detected in the most samples, 31 of 58 , and at the most sampling sites, eight of nine. Prometon was detected in 29 of 58 samples; all prometon detections were at sites 11 to 17 . The diazinon concentration of $0.21 \mu \mathrm{g} / \mathrm{L}$ at site 11 in September 1995 was the largest concentration of any pesticide detected at a basic-fixed site. The second largest concentration was an estimated $0.068 \mu \mathrm{g} / \mathrm{L}$ of carbofuran detected at site 15 in April 1995. Of the 152 detections, 91 were uncensored values at or above their corresponding MDL's, 47 were estimated values below their corresponding MDL's, and the 9 carbofuran and 5 carbaryl detections were estimated values because of the poor performance record of these two pesticides analyzed with the C-18 method (Zaugg and others, 1995). Table 42 gives summary statistics for the pesticide analytes detected.

On an individual site basis, pesticides were detected at all nine basic-fixed sites that were sampled. The number of detections ranged from 1 detection out of 188 analyses at site 3 to 39 detections out of 797 analyses at site 17 . The number of analytes detected ranged from 1 at site 3 to 10 at sites 16 and 17 . In comparing the samples collected during the summer of 1995 , the number of analytes detected increased from the upper part of the basin, one at site 3, to the lower part of the basin, eight at site 16 . The number of detections also generally increased from the upper to the lower part of the basin except at site 11, which had the second highest number of detections during this time period. Table 43 summarizes pesticide analyses and detections at the nine sites sampled, and table 44 lists the uncensored and estimated concentrations for all detections at these sites. 
Table 40. --Summary statistics for organic carbon analytes

[All concentrations are in milligrams per liter. Num, number of samples; min, minimum; med, median; max, maximum. --, not applicable]

\begin{tabular}{|c|c|c|c|c|c|c|c|c|c|c|c|c|}
\hline \multirow{2}{*}{$\begin{array}{c}\text { Site } \\
\text { number } \\
\text { (table 1) }\end{array}$} & \multicolumn{4}{|c|}{ Total } & \multicolumn{4}{|c|}{ Dissolved } & \multicolumn{4}{|c|}{ Suspended } \\
\hline & Num & Min & Med & $\operatorname{Max}$ & Num & Min & Med & Max & Num & Min & Med & Max \\
\hline 1 & 1 & -- & 4.4 & -- & 7 & 1.8 & 2.4 & 4.8 & 6 & 0.3 & 0.45 & 3.5 \\
\hline 2 & 1 & -- & 4.5 & -- & 6 & 2.2 & 2.95 & 13 & 6 & .5 & 1.3 & 2.1 \\
\hline 3 & 1 & -- & 5.9 & -- & 6 & 1.9 & 2.5 & 5.2 & 6 & .2 & .6 & 1.2 \\
\hline 4 & 1 & -- & 8.0 & -- & 6 & 3.2 & 4.75 & 9.0 & 6 & .7 & .7 & 2.3 \\
\hline 5 & 1 & -- & 6.3 & -- & 6 & 1.4 & 2.0 & 9.7 & 7 & .4 & .6 & 1.8 \\
\hline 6 & 1 & -- & 9.8 & -- & 7 & 3.0 & 5.5 & 8.0 & 6 & .4 & 1.0 & 2.7 \\
\hline 7 & 10 & 2.2 & 4.4 & 11 & 6 & 1.8 & 2.85 & 20 & 6 & .3 & 1.1 & 3.0 \\
\hline 8 & 1 & -- & 7.4 & -- & 6 & 3.8 & 4.65 & 22 & 6 & .5 & .6 & .7 \\
\hline 9 & 1 & -- & 8.1 & -- & 6 & 2.8 & 4.45 & 20 & 6 & .5 & .8 & 1.1 \\
\hline 10 & 1 & -- & 4.9 & -- & 6 & 2.2 & 2.95 & 7.9 & 5 & .4 & .5 & 1.5 \\
\hline II & 2 & 7.2 & -- & 12 & 8 & 5.6 & 6.65 & 9.4 & 6 & .3 & .65 & 5.0 \\
\hline 12 & 11 & 4.4 & 6.5 & 25 & 7 & 3.3 & 4.1 & 25 & 6 & 1.0 & 1.5 & 5.5 \\
\hline 13 & 1 & -- & 260 & -- & 2 & 6.6 & -- & 7.5 & 0 & -- & -- & -- \\
\hline 14 & 1 & -- & 9.7 & -- & 6 & 3.1 & 3.35 & 6.2 & 4 & 1.2 & 2.3 & 4.1 \\
\hline 15 & 2 & 6.5 & -- & 11 & 3 & 4.7 & 5.3 & 26 & 2 & 3.6 & 4.2 & 4.8 \\
\hline 16 & 2 & 4.1 & -- & 7.4 & 12 & 3.1 & 4.2 & 7.5 & 11 & .2 & .9 & 1.5 \\
\hline 17 & 2 & 5.0 & -- & 7.3 & 11 & 3.2 & 3.8 & 5.7 & 11 & .7 & 1.7 & 2.9 \\
\hline
\end{tabular}


Table 41.--Basic-fixed sites at which pesticide samples were collected

\begin{tabular}{|c|c|c|c|}
\hline $\begin{array}{c}\text { Site } \\
\text { number } \\
\text { (table 1) } \\
\end{array}$ & $\begin{array}{c}\text { Number } \\
\text { of } \\
\text { samples }\end{array}$ & $\begin{array}{c}\text { Time } \\
\text { period }\end{array}$ & Study ${ }^{1}$ \\
\hline 3 & 4 & June-September 1995 & Network sampling \\
\hline 6 & 6 & May-September 1995 & Network sampling \\
\hline 9 & 5 & April-August 1995 & Network sampling \\
\hline 11 & 4 & June-September 1995 & Network sampling \\
\hline 12 & $\begin{array}{l}1 \\
6\end{array}$ & $\begin{array}{c}\text { August } 1994 \\
\text { April-September } 1995\end{array}$ & $\begin{array}{l}\text { Survey sample } \\
\text { Network sampling }\end{array}$ \\
\hline 14 & 5 & April-August 1995 & Network sampling \\
\hline 15 & 5 & April-August 1995 & Network sampling \\
\hline \multirow[t]{2}{*}{16} & 6 & $\begin{array}{l}\text { April-May } 1994 \\
\text { January } 1995\end{array}$ & $\begin{array}{l}\text { Mesilla Valley } \\
\text { synoptic }\end{array}$ \\
\hline & 5 & April-August 1995 & Network sampling \\
\hline \multirow[t]{2}{*}{17} & 7 & $\begin{array}{l}\text { April-May } 1994 \\
\text { January } 1995\end{array}$ & $\begin{array}{l}\text { Mesilla Valley } \\
\text { synoptic }\end{array}$ \\
\hline & 4 & April-August 1995 & Network sampling \\
\hline
\end{tabular}

'All samples were analyzed by the C-18 solid-phase extraction method. The survey sample at site 12 and Mesilla Valley synoptic samples also were analyzed by the Carbopak-B solid-phase extraction method. 


\section{Table 42.--Summary of pesticide analytes detected at basic-fixed sites}

[U.S. Geological Survey's Water-Data Storage and Retrieval System (WATSTORE) parameter code: D, C18 solid-phase extraction method; A, Carbopak-B solid-phase extraction method. All concentrations are in micrograms per liter. E, estimated value; --, not applicable]

\begin{tabular}{|c|c|c|c|c|c|c|c|c|c|}
\hline \multirow{2}{*}{$\frac{\text { Analyte }}{\text { Atrazine }}$} & \multirow{2}{*}{$\begin{array}{c}\begin{array}{c}\text { Parameter } \\
\text { code }\end{array} \\
39632 \mathrm{D}\end{array}$} & \multirow{2}{*}{$\begin{array}{c}\begin{array}{c}\text { Method } \\
\text { detection } \\
\text { limit }\end{array} \\
0.001\end{array}$} & \multirow{2}{*}{$\begin{array}{c}\begin{array}{c}\text { Number } \\
\text { of } \\
\text { analyses }\end{array} \\
58\end{array}$} & \multicolumn{2}{|c|}{$\begin{array}{c}\begin{array}{c}\text { Number of } \\
\text { detections }\end{array} \\
\text { Uncensored Estimated }\end{array}$} & \multirow{2}{*}{$\begin{array}{c}\begin{array}{c}\text { Number } \\
\text { of } \\
\text { sites }\end{array} \\
3\end{array}$} & \multicolumn{3}{|c|}{$\frac{\text { Concentration }}{\text { Minimum Median Maximum }}$} \\
\hline & & & & 5 & 0 & & 0.003 & 0.004 & 0.006 \\
\hline Carbaryl $^{2}$ & $82680 \mathrm{D}$ & .003 & 58 & 0 & 5 & 3 & E.002 & E.026 & E. 044 \\
\hline Carbofuran ${ }^{2}$ & $82674 \mathrm{D}$ & .003 & 58 & 0 & 9 & 4 & E.006 & E.016 & E.068 \\
\hline Chlorpyrifos & $38933 \mathrm{D}$ & .004 & 58 & 5 & 0 & 2 & .005 & .006 & .008 \\
\hline DCPA & $82682 \mathrm{D}$ & .002 & 58 & 13 & 4 & 3 & E.001 & .005 & .021 \\
\hline$p, p{ }^{\prime} D D E$ & $34653 \mathrm{D}$ & .006 & 58 & 0 & 3 & 3 & E.001 & E.002 & E.002 \\
\hline Diazinon & 39572D & .002 & 58 & 14 & 0 & 6 & .003 & .0085 & .21 \\
\hline Diuron & $49300 \mathrm{~A}$ & .020 & 14 & 0 & 1 & 1 & -- & E.001 & -- \\
\hline ЕРТC & $82668 \mathrm{D}$ & .002 & 58 & 2 & 1 & 2 & E.001 & .004 & .010 \\
\hline Lindane & $39341 \mathrm{D}$ & .004 & 58 & 3 & 0 & 1 & .009 & .011 & .040 \\
\hline Malathion & $39532 \mathrm{D}$ & .005 & 58 & 2 & 1 & 3 & E.003 & .007 & .009 \\
\hline Metolachlor & $39415 \mathrm{D}$ & .002 & 58 & 13 & 0 & 4 & .002 & .003 & .008 \\
\hline Prometon & 04037D & .018 & 58 & 2 & 27 & 6 & E.003 & E.007 & .039 \\
\hline Propargite & $82685 \mathrm{D}$ & .004 & 58 & 1 & 0 & 1 & -- & .055 & -- \\
\hline Simazine & 04035D & .005 & 58 & 28 & 3 & 8 & E.002 & .009 & .059 \\
\hline Tebuthiuron & $82670 \mathrm{D}$ & .010 & 58 & 2 & 7 & 6 & E.004 & E.007 & .018 \\
\hline Trifluralin & $82661 \mathrm{D}$ & .002 & 58 & 1 & 0 & 1 & -- & .010 & -- \\
\hline
\end{tabular}

${ }^{1}$ Uncensored detections are data to which an unqualified value can be assigned. Estimated detections are of two types. Estimated concentrations below the method detection limit lack the statistical confidence that they are not equal to zero. Estimated concentrations at or above the method detection limit result from matrix interference with the analytical procedure or a poor or variable performance record of the analyte with the analytical procedure used.

2 The five carbaryl detections and nine carbofuran detections are estimated values because of poor performance records of these analytes with the $\mathrm{C}$ - 18 solid-phase extraction method. 
Table 43.--Summary of pesticide detections at basic-fixed sites

[SPE, solid-phase extraction; --, not applicable]

\begin{tabular}{|c|c|c|c|c|c|c|c|c|}
\hline \multirow[b]{2}{*}{$\begin{array}{c}\text { Site } \\
\text { number } \\
\text { (table 1) }\end{array}$} & \multicolumn{4}{|c|}{ C-18 SPE method } & \multicolumn{4}{|c|}{ Carbopak-B SPE method } \\
\hline & $\begin{array}{c}\text { Number } \\
\text { of } \\
\text { samples }\end{array}$ & $\begin{array}{c}\text { Number } \\
\text { of } \\
\text { analyses }\end{array}$ & $\begin{array}{c}\text { Number } \\
\text { of } \\
\text { detections }\end{array}$ & $\begin{array}{c}\text { Number } \\
\text { of } \\
\text { analytes } \\
\text { detected }\end{array}$ & $\begin{array}{c}\text { Number } \\
\text { of } \\
\text { samples }\end{array}$ & $\begin{array}{c}\text { Number } \\
\text { of } \\
\text { analyses }\end{array}$ & $\begin{array}{c}\text { Number } \\
\text { of } \\
\text { detections }\end{array}$ & $\begin{array}{c}\text { Number } \\
\text { of } \\
\text { analytes } \\
\text { detected }\end{array}$ \\
\hline 3 & 4 & 188 & 1 & 1 & 0 & -- & -- & -- \\
\hline 6 & 6 & 282 & 5 & 4 & 0 & -- & -- & -- \\
\hline 9 & 5 & 235 & 5 & 5 & 0 & -- & -- & -- \\
\hline 11 & 4 & 188 & 15 & 5 & 0 & -- & -- & -- \\
\hline 12 & 7 & 328 & 18 & 7 & 1 & 41 & 0 & 0 \\
\hline 14 & 5 & 235 & 14 & 7 & 0 & -- & -- & -- \\
\hline 15 & 5 & 235 & 19 & 8 & 0 & -- & -- & -- \\
\hline 16 & 11 & 512 & 36 & 10 & 6 & 237 & 1 & 1 \\
\hline 17 & 11 & 511 & 39 & 10 & 7 & 286 & 0 & 0 \\
\hline All sites & 58 & 2,714 & 152 & 17 & 14 & 564 & 1 & 1 \\
\hline
\end{tabular}


Table 44.--Pesticide detections at basic-fixed sites

[All concentrations in micrograms per liter. $\mathrm{C}$, censored data; $\mathrm{E}$, estimated data ${ }^{\mathrm{C}}$ ]

\begin{tabular}{|c|c|c|c|c|c|c|c|c|c|}
\hline $\begin{array}{c}\text { Site } \\
\text { number } \\
\text { (table 1) }\end{array}$ & Date & $\begin{array}{l}\text { Atra- } \\
\text { zine }\end{array}$ & $\begin{array}{l}\text { Car- } \\
\text { baryl }\end{array}$ & $\begin{array}{l}\text { Carbo- } \\
\text { furan }\end{array}$ & $\begin{array}{l}\text { Chlor- } \\
\text { pyrifos }\end{array}$ & DCPA & p,p'DDE & $\begin{array}{l}\text { Dia- } \\
\text { zinon }\end{array}$ & Diuron \\
\hline 3 & $09 / 06 / 95$ & C & C & C & C & C & E 0.001 & C & C \\
\hline \multirow[t]{3}{*}{6} & $06 / 13 / 95$ & C & C & C & C & C & C & C & C \\
\hline & $07 / 19 / 95$ & C & C & C & C & C & C & C & C \\
\hline & $09 / 05 / 95$ & C & C & C & C & C & C & 0.008 & C \\
\hline \multirow[t]{4}{*}{9} & $04 / 18 / 95$ & C & C & C & $\mathrm{C}$ & C & C & C & C \\
\hline & $05 / 16 / 95$ & C & C & C & C & C & C & .008 & C \\
\hline & $06 / 21 / 95$ & C & C & C & C & C & C & C & C \\
\hline & $07 / 26 / 95$ & C & C & C & C & C & C & C & C \\
\hline \multirow[t]{4}{*}{11} & $06 / 07 / 95$ & C & C & C & C & $\mathrm{C}$ & C & .009 & C \\
\hline & $07 / 06 / 95$ & C & E0.026 & C & C & C & C & .023 & C \\
\hline & $08 / 02 / 95$ & C & E.036 & C & C & $\mathrm{C}$ & C & .022 & C \\
\hline & $09 / 06 / 95$ & c & C & $\mathrm{C}$ & $\mathrm{C}$ & $\mathrm{C}$ & C & .21 & $\mathrm{C}$ \\
\hline \multirow{6}{*}{12} & $(08 / 31 / 94$ & C & E.044 & C & 0.006 & C & C & .025 & $\mathrm{C}$ \\
\hline & $04 / 27 / 95$ & C & C & C & C & C & C & C & C \\
\hline & $05 / 31 / 95$ & $\mathrm{C}$ & $\mathrm{C}$ & C & C & C & C & .003 & C \\
\hline & $06 / 23 / 95$ & C & C & C & C & C & C & C & C \\
\hline & $07 / 12 / 95$ & C & E.002 & $\mathrm{C}$ & C & C & C & C & C \\
\hline & $09 / 05 / 95$ & C & $\mathrm{C}$ & C & .006 & $\mathrm{C}$ & $\mathrm{C}$ & .025 & C \\
\hline \multirow[t]{5}{*}{14} & $04 / 20 / 95$ & C & C & $\mathrm{E} 0.031$ & C & $\mathrm{C}$ & C & $\mathrm{C}$ & $\mathrm{C}$ \\
\hline & $05 / 24 / 95$ & C & C & $C$ & $\mathrm{C}$ & C & C & C & C \\
\hline & $06 / 28 / 95$ & C & E. 012 & C & C & C & C & C & C \\
\hline & $07 / 26 / 95$ & $\mathrm{C}$ & C & C & C & C & C & C & C \\
\hline & $08 / 30 / 95$ & C & C & C & C & C & C & .004 & C \\
\hline \multirow[t]{5}{*}{15} & $04 / 19 / 95$ & 0.004 & C & E.068 & C & C & C & .005 & C \\
\hline & $05 / 24 / 95$ & C & C & C & C & C & C & .003 & C \\
\hline & $06 / 28 / 95$ & C & $\mathrm{C}$ & $C$ & C & $\mathrm{C}$ & C & .004 & C \\
\hline & $07 / 26 / 95$ & C & $C$ & C & C & C & C & C & $\mathrm{C}$ \\
\hline & $08 / 30 / 95$ & C & C & C & $\mathrm{C}$ & E0.001 & C & .009 & C \\
\hline \multirow[t]{11}{*}{16} & $04 / 13 / 94$ & $\mathrm{C}$ & C & E. 016 & C & .005 & C & C & C \\
\hline & $04 / 18 / 94$ & C & C & C & $\mathrm{C}$ & .004 & E. 002 & C & C \\
\hline & $04 / 26 / 94$ & C & $\mathrm{C}$ & E.006 & C & $\mathrm{C}$ & $\mathrm{C}$ & C & C \\
\hline & $05 / 04 / 94$ & C & C & $\mathrm{C}$ & C & .003 & C & $\mathrm{C}$ & C \\
\hline & $05 / 10 / 94$ & C & $\mathrm{C}$ & C & C & C & C & C & C \\
\hline & $01 / 04 / 95$ & C & $\mathrm{C}$ & $\mathrm{C}$ & $\mathrm{C}$ & .003 & $\mathrm{C}$ & C & E0.001 \\
\hline & $04 / 18 / 95$ & $\mathrm{C}$ & C & E.029 & C & .006 & $\mathrm{C}$ & C & C \\
\hline & $05 / 22 / 95$ & $C$ & C & C & C & .012 & C & C & C \\
\hline & $06 / 26 / 95$ & .004 & C & E. 010 & C & .008 & C & C & C \\
\hline & $07 / 25 / 95$ & C & C & C & C & C & C & C & C \\
\hline & $08 / 29 / 95$ & C & $\mathrm{C}$ & $\mathrm{C}$ & $\mathrm{C}$ & E.001 & C & $\mathrm{C}$ & $\mathrm{C}$ \\
\hline \multirow[t]{11}{*}{17} & $04 / 06 / 94$ & .006 & C & C & .008 & .012 & C & C & C \\
\hline & $04 / 12 / 94$ & C & C & E.013 & C & .006 & C & C & C \\
\hline & $04 / 19 / 94$ & .004 & $\mathrm{C}$ & C & $\mathrm{C}$ & .005 & C & C & C \\
\hline & $04 / 28 / 94$ & C & C & E.022 & $\mathrm{C}$ & $\mathrm{C}$ & C & C & C \\
\hline & $05 / 03 / 94$ & C & $\mathrm{C}$ & 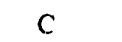 & $\mathrm{C}$ & C & $\mathrm{C}$ & C & C \\
\hline & $05 / 11 / 94$ & $\mathrm{C}$ & $\mathrm{C}$ & $\mathrm{C}$ & $\mathrm{C}$ & $\mathrm{C}$ & C & C & C \\
\hline & $01 / 07 / 95$ & $\mathrm{C}$ & $\mathrm{C}$ & $\mathrm{C}$ & $\mathrm{C}$ & .021 & E.002 & C & C \\
\hline & $04 / 18 / 95$ & $\mathrm{C}$ & $\mathrm{C}$ & E.011 & $\mathrm{C}$ & .009 & $\mathrm{C}$ & C & C \\
\hline & $05 / 23 / 95$ & C & C & C & .005 & .008 & C & C & C \\
\hline & $06 / 27 / 95$ & .003 & $\mathrm{C}$ & C & C & E.001 & C & $\mathrm{C}$ & C \\
\hline & $08 / 29 / 95$ & $\mathrm{C}$ & C & C & .008 & E.001 & C & $\mathrm{C}$ & C \\
\hline
\end{tabular}


Table 44.--Pesticide detections at basic-fixed sites--Concluded

\begin{tabular}{|c|c|c|c|c|c|c|c|c|c|c|}
\hline $\begin{array}{c}\text { Site } \\
\text { number } \\
\text { (table 1) }\end{array}$ & Date & EPTC & Lindane & $\begin{array}{l}\text { Mala- } \\
\text { thion }\end{array}$ & $\begin{array}{l}\text { Meto- } \\
\text { lachlor }\end{array}$ & $\begin{array}{c}\text { Pro- } \\
\text { meton }\end{array}$ & $\begin{array}{l}\text { Propar- } \\
\text { gite }\end{array}$ & $\begin{array}{c}\text { Sima- } \\
\text { zine }\end{array}$ & $\begin{array}{l}\text { Tebu- } \\
\text { thiuron }\end{array}$ & $\begin{array}{c}\text { Triffu- } \\
\text { ralin }\end{array}$ \\
\hline 3 & $09 / 06 / 95$ & C & C & $\mathrm{C}$ & C & C & C & C & C & C \\
\hline \multirow[t]{3}{*}{6} & $06 / 13 / 95$ & 0.010 & $\mathrm{C}$ & C & $\mathrm{C}$ & $\mathrm{C}$ & C & C & $\mathrm{C}$ & $\mathrm{C}$ \\
\hline & $07 / 19 / 95$ & E.001 & $\mathrm{C}$ & 0.009 & C & $\mathrm{C}$ & C & E0.002 & C & C \\
\hline & $09 / 05 / 95$ & C & C & C & C & C & C & $\mathrm{C}$ & C & C \\
\hline \multirow[t]{4}{*}{9} & $04 / 18 / 95$ & C & C & C & $\mathrm{C}$ & C & C & C & 0.010 & C \\
\hline & $05 / 16: 95$ & $\mathrm{C}$ & C & $\mathrm{C}$ & C & C & $\mathrm{C}$ & $\mathrm{C}$ & $\mathrm{C}$ & C \\
\hline & $06 / 21 / 95$ & .004 & C & C & C & C & $\mathrm{C}$ & C & $\mathrm{C}$ & $\mathrm{C}$ \\
\hline & $07 / 26 / 95$ & $\mathrm{C}$ & C & .007 & C & C & C & E.003 & C & C \\
\hline \multirow[t]{4}{*}{11} & $06: 07: 95$ & C & 0.009 & C & $\mathrm{C}$ & E0.005 & C & $\mathrm{C}$ & C & $\mathrm{C}$ \\
\hline & $07 / 06 / 95$ & C & C & C & $\mathrm{C}$ & .039 & $\mathrm{C}$ & $\mathrm{C}$ & C & $\mathrm{C}$ \\
\hline & $08: 0295$ & C & .011 & C & C & E. 009 & C & .006 & C & C \\
\hline & $09 / 06 / 95$ & C & .040 & C & C & E. 012 & C & .006 & C & C \\
\hline \multirow[t]{6}{*}{12} & $0 \times 3194$ & C & $\mathrm{C}$ & C & $\mathrm{C}$ & 0.031 & $\mathrm{C}$ & .059 & C & C \\
\hline & $04: 27105$ & C & $\mathrm{C}$ & C & $\mathrm{C}$ & E.005 & $\mathrm{C}$ & .009 & E.007 & $\mathrm{C}$ \\
\hline & 55/31'41 & c & C & C & C & E.004 & $\mathrm{C}$ & $\mathrm{C}$ & $\mathrm{C}$ & $\mathrm{C}$ \\
\hline & $06 / 23 / 95$ & C & C & $\mathrm{C}$ & C & $\mathrm{C}$ & $\mathrm{C}$ & .016 & C & $\mathrm{C}$ \\
\hline & $07 / 12 / 95$ & C & C & E.003 & $\mathrm{C}$ & C & C & .016 & C & C \\
\hline & $09 ; 05: 95$ & C & C & C & $\mathrm{C}$ & E.005 & $\mathrm{C}$ & .022 & C & C \\
\hline \multirow[t]{5}{*}{14} & $04 / 20 / 95$ & $\mathrm{C}$ & C & C & $\mathrm{C}$ & E.004 & $\mathrm{C}$ & .009 & E.004 & $\mathrm{C}$ \\
\hline & $05 / 24 / 95$ & $\mathrm{C}$ & C & $\mathrm{C}$ & $\mathrm{C}$ & $\mathrm{C}$ & C & .022 & $\mathrm{C}$ & $\mathrm{C}$ \\
\hline & $06 / 28: 95$ & C & $\mathrm{C}$ & C & 0.002 & E.004 & $\mathrm{C}$ & .009 & C & C \\
\hline & $07^{2} 26 / 95$ & $\mathrm{C}$ & C & $\mathrm{C}$ & $\mathrm{C}$ & $\mathrm{C}$ & $\mathrm{C}$ & .007 & $\mathrm{C}$ & $\mathrm{C}$ \\
\hline & $08 / 30 / 95$ & C & C & C & C & E.005 & C & .005 & E.008 & C \\
\hline \multirow[t]{5}{*}{15} & $04 / 19 / 95$ & C & C & C & $\mathrm{C}$ & E. 004 & $\mathrm{C}$ & .018 & E.006 & $\mathrm{C}$ \\
\hline & $05 / 24 / 95$ & $\mathrm{C}$ & $\mathrm{C}$ & $\mathrm{C}$ & $\mathrm{C}$ & $\mathrm{C}$ & $\mathrm{C}$ & .056 & E.005 & C \\
\hline & $06 / 28 / 95$ & $\mathrm{C}$ & C & $\mathrm{C}$ & .002 & E.003 & $\mathrm{C}$ & .022 & C & C \\
\hline & $07 / 26 / 95$ & C & $\mathrm{C}$ & C & C & $\mathrm{C}$ & C & .022 & C & C \\
\hline & 08/30/95 & $\mathrm{CC}$ & C & C & C & E.005 & C & E.004 & .018 & C \\
\hline \multirow[t]{11}{*}{16} & $04 / 13 / 94$ & $\mathrm{C}$ & $\mathrm{C}$ & C & .008 & $\mathrm{C}$ & $\mathrm{C}$ & C & $\mathrm{C}$ & C \\
\hline & $04 / 18 / 94$ & $\mathrm{C}$ & $\mathrm{C}$ & C & $\mathrm{C}$ & E.009 & C & .007 & $\mathrm{C}$ & C \\
\hline & $04 / 26 / 94$ & $\mathrm{C}$ & C & C & $\mathrm{C}$ & E.008 & $\mathrm{C}$ & $\mathrm{C}$ & C & $\mathrm{C}$ \\
\hline & $05 / 04 / 94$ & C & C & C & C & E.009 & C & $\mathrm{C}$ & C & C \\
\hline & $05 / 10 / 94$ & C & C & C & C & C & C & $\mathrm{C}$ & C & C \\
\hline & $01 / 04 / 95$ & C & C & $\mathrm{C}$ & .008 & C & C & C & $\mathrm{C}$ & C \\
\hline & $04 / 18 / 95$ & $\mathrm{C}$ & C & $\mathrm{C}$ & .002 & E.009 & C & .010 & $\mathrm{C}$ & $\mathrm{C}$ \\
\hline & $05 / 22 / 95$ & C & C & $\mathrm{C}$ & C & E.007 & C & .010 & $\mathrm{C}$ & $\mathrm{C}$ \\
\hline & $06 / 26 / 95$ & $\mathrm{C}$ & $\mathrm{C}$ & $\mathrm{C}$ & .005 & E.009 & 0.055 & .009 & $\mathrm{C}$ & C \\
\hline & $07 / 25 / 95$ & $\mathrm{C}$ & $\mathrm{C}$ & $\mathrm{C}$ & $\mathrm{C}$ & E.007 & $\mathrm{C}$ & .013 & C & C \\
\hline & 08/29/95 & C & C & C & .005 & E. 007 & C & .011 & Е.008 & C \\
\hline \multirow{11}{*}{17} & $04 / 06 / 94$ & $\mathrm{C}$ & $\mathrm{C}$ & $\mathrm{C}$ & .003 & $\mathrm{C}$ & $\mathrm{C}$ & .008 & $\mathrm{C}$ & C \\
\hline & $04 / 12 / 94$ & C & C & C & $\mathrm{C}$ & C & C & $\mathrm{C}$ & $\mathrm{C}$ & $\mathrm{C}$ \\
\hline & $04 / 19 / 94$ & C & C & $\mathrm{C}$ & C & E.007 & C & .006 & $\mathrm{C}$ & $\mathrm{C}$ \\
\hline & $04 / 28 / 94$ & C & C & C & C & E.009 & C & C & C & C \\
\hline & $05 / 03 / 94$ & C & C & C & C & E.008 & $\mathrm{C}$ & $\mathrm{C}$ & C & C \\
\hline & $05 / 11 / 94$ & C & C & C & C & C & C & C & C & C \\
\hline & $01 / 07 / 95$ & C & C & $\mathrm{C}$ & .007 & $\mathrm{C}$ & $\mathrm{C}$ & $\mathrm{C}$ & $\mathrm{C}$ & 0.010 \\
\hline & $04 / 18 / 95$ & C & $\mathrm{C}$ & $\mathrm{C}$ & .002 & E.007 & $\mathrm{C}$ & .009 & C & $\mathrm{C}$ \\
\hline & $05 / 23 / 95$ & $\mathrm{C}$ & C & $\mathrm{C}$ & .002 & E.005 & C & .007 & C & $\mathrm{C}$ \\
\hline & $06 / 27 / 95$ & C & $\mathrm{C}$ & $\mathrm{C}$ & .003 & E.008 & $\mathrm{C}$ & .010 & C & $\mathrm{C}$ \\
\hline & $08 / 29 / 95$ & C & $\mathrm{C}$ & $\mathrm{C}$ & .004 & E.007 & $\mathrm{C}$ & .008 & E.006 & $\mathrm{C}$ \\
\hline
\end{tabular}




\section{SUMMARY}

As part of the RIOG NAWQA program, watercolumn samples were collected monthly at a network of 17 basic-fixed sites from April 1993 through September 1995 for the analyses of DS, major constituents, nutrients, selected trace elements, and suspended-sediment concentrations. During selected sampling events, samples also were collected for analysis of additional trace elements, organic carbon, and pesticides.

Instantaneous streamflow was smallest at the indicator sites on the perennial streams draining small basins and was largest at integrator sites 9 and 12 on the main stem. The median instantaneous streamflow at each individual site ranged from $1.4 \mathrm{ft}^{3} / \mathrm{s}$ at site 10 to $1,380 \mathrm{ft}^{3} / \mathrm{s}$ at site 9 . Median specific conductance for each site ranged from $84 \mu \mathrm{S} / \mathrm{cm}$ at site 3 to 1,680 $\mu \mathrm{S} / \mathrm{cm}$ at site 13 , and the median $\mathrm{pH}$ values ranged from 7.8 at sites 1,3 , and 10 to 8.5 at site 11 . The water sampled at the basic-fixed sites was generally well oxygenated and had a median DO percent of saturation ranging from 89 at site 12 to 108 at site 6 .

With the exception of site 4, DS concentrations generally increased in the main stem of the Rio Grande in a downstream direction. This increase is from natural sources, such as ground-water inflow and evapotranspiration, and from anthropogenic sources, such as irrigation-return flows, urban runoff, and WWTP discharges. The smallest median DS concentration was $58 \mathrm{mg} / \mathrm{L}$ at site 3 , and the largest median DS concentration was $1,240 \mathrm{mg} / \mathrm{L}$ at site 13 .

The spatial distribution of calcium, magnesium, sodium, sulfate, chloride, and fluoride was similar to the spatial distribution of DS, although the differences in concentrations among sites varied for different constituents. For potassium, the major difference in spatial distribution was the decrease in median concentration from site 6 to site 9 . For bicarbonate, the largest median concentration was at site 11 , and the median concentration at site 13 was approximately equal to that at site 12 .

Of all cations, calcium and sodium had the largest concentrations at most sites. Calcium was the predominant cation at sites $1-3,5,7-9$, and 12 . Sodium was the predominant cation at sites 11 and 17 . For the remainder of the sites, neither calcium nor sodium was predominant; however, calcium exceeded sodium in percentage of total cation milliequivalents per liter at sites 4,6 , and 15 , they were approximately equal at site 10 , and sodium exceeded calcium at sites 13,14 , and
I6. Site 3 differed from the other basic-fixed sites in that magnesium exceeded sodium.

Of all anions, bicarbonate and sulfate had the largest concentrations at most sites. Bicarbonate was the predominant anion at all sites except 13, 14, 16, and 17. Sulfate was the predominant anion at site 13 . Bicarbonate exceeded sulfate in percentage of total anion milliequivalents per liter at site 14; they were approximately equal at site 16 ; and sulfate exceeded bicarbonate at site 17 . Sites 10 and 11 differed from the other basic-fixed sites in that chloride exceeded sulfate.

Silica had the largest concentration at site 10 , where silica accounted for approximately 50 percent of the DS. Silica also was important at sites 1, 2, and 5 , where it accounted for approximately 30 percent of the DS, and at site 3, where it accounted for approximately 20 percent of the DS. For the remaining sites, silica concentration as a percentage of DS concentration generally decreased downstream as the concentration of DS increased.

The largest concentrations and largest median concentrations for the dissolved-nutrient analytes were detected at sites 11 and 12 . The relatively large dissolved-nutrient concentrations at these sites probably were due to discharges from WWTP's and urban runoff. The second largest median concentration for $\mathrm{NO}_{2}+\mathrm{NO}_{3}$ was at site 13; the larger concentrations of $\mathrm{NO}_{2}+\mathrm{NO}_{3}$ at this site were associated with runoff from summer thunderstorms.

The largest concentrations and largest median concentrations of total ammonia plus organic nitrogen and total phosphorus were detected at site 13. As with $\mathrm{NO}_{2}+\mathrm{NO}_{3}$, the largest concentrations of these nutrients at this site were associated with runoff from summer thunderstorms.

Dissolved-iron concentrations ranged from censored values at sites $13-17$ to $914 \mu \mathrm{g} / \mathrm{L}$ at site 13 . Median concentrations ranged from $3 \mu \mathrm{g} / \mathrm{L}$ at sites 16 and 17 to $160 \mu \mathrm{g} / \mathrm{L}$ at site 2 . Dissolved-manganese concentrations ranged from censored concentrations at sites $13-17$ to $300 \mu \mathrm{g} / \mathrm{L}$ at site 4 . Median concentrations ranged from $1 \mu \mathrm{g} / \mathrm{L}$ at site 15 to $68 \mu \mathrm{g} / \mathrm{L}$ at site 4 .

The maximum concentrations of most total recoverable trace elements were detected at site 13 , due to the large suspended-sediment concentrations at this site. Concentrations of dissolved antimony, beryllium, cadmium, mercury, and silver were smaller than their respective MRL's in all samples. Concentrations of dissolved chromium, cobalt, lead, selenium, and vanadium were smaller than their respective MRL's in 
more than 80 percent of the samples. Concentrations of dissolved arsenic, copper, and nickel were near or smaller than their respective MRL's in more than 50 percent of the samples. Concentrations of dissolved barium, boron, lithium, molybdenum, strontium, and uranium increased in a downstream direction, although the largest concentrations of boron, strontium, and uranium were detected at site 13 .

There was a total of 152 detections of 17 pesticides from 3,278 analyses of 88 pesticide analytes. Simazine was detected in the most samples, 31 of 58 , and at the most sampling sites, eight of nine. Prometon was detected in 29 of 58 samples, all at sites $11-17$. The diazinon concentration of $0.21 \mu \mathrm{g} / \mathrm{L}$ at site 11 in September 1995 was the largest concentration of any pesticide detected at a basic-fixed site. The second largest concentration was an estimated $0.068 \mu \mathrm{g} / \mathrm{L}$ of carbofuran detected at site 15 in April 1995. Of the 152 detections, 91 were uncensored values at or above their respective MDL's, 47 were estimated values below their respective MDL's, and the 9 carbofuran and 5 carbaryl detections were estimated values because of the poor performance record of these two pesticides analyzed with the C-18 method.

On a individual site basis, pesticides were detected at all nine sites that were sampled. The number of detections ranged from 1 detection out of 188 analyses at site 3 to 39 detections out of 797 analyses at site 17 . The number of analytes detected ranged from 1 at site 3 to 10 at sites 16 and 17 . In comparing the samples collected during the summer of 1995, the number of analytes detected increased from the upper part of the basin, one at site 3, to the lower part of the basin. eight at site 16 .

\section{REFERENCES}

Anderholm, S.K., 1996, Water-quality assessment of the Rio Grande Valley study unit, Colorado, New Mexico, and Texas--Shallow ground-water quality of a land-use area in the San Luis Valley, south-central Colorado, 1993: U.S. Geological Survey Water-Resources Investigations Report 96-4144, 94 p.

Anderholm, S.K., Radell, M.J., and Richey, S.F., 1995, Water-quality assessment of the Rio Grande Valley study unit, Colorado, New Mexico, and Texas--Analysis of selected nutrient, suspended-sediment, and pesticide data: U.S. Geological Survey Water-Resources Investigations Report 94-4061, $203 \mathrm{p}$.

Anderson, J.R., Hardy, E.E., Roach, J.T., and Witmer, R.E., 1976, A land use and land cover classification system for use with remote sensor data: U.S. Geological Survey Professional Paper 964, 28 p.

Bexfield, L.M., and Anderholm, S.K., 1997, Water-quality assessment of the Rio Grande Valley study unit, Colorado, New Mexico, and Texas--Ground-water quality in the Rio Grande flood plain, Cochiti Lake, New Mexico, to El Paso, Texas, 1995: U.S. Geological Survey Water-Resources Investigations Report 96-4249. $93 \mathrm{p}$.

Borland, J.P., and Ong, Kim, 1995, Water resources data, New Mexico, water year 1994: U.S. Geological Survey Water-Data Report NM-94-1, 581 p.

Buchanan, T.J., and Somers. W.P., 1969, Discharge measurements at gaging stations: U.S. Geological Survey Techniques of Water-Resources Investigations, book 3, chap. A8, 65 p.

Bureau of Reclamation, 1977, Operation and maintenance program for the Rio Grande, Velarde to Caballo Dam, Rio Grande and Middle Rio Grande projects, New Mexico: Final environmental statement, v. 1, sec. A through $\mathrm{H}, 429 \mathrm{p}$.

1997, High flows and sediment to blame for choking up Rio Grande Low Flow Conveyance Channel, in The Rio Grande Low Flow Conveyance Channel Messenger: Socorro, N. Mex., Bureau of Reclamation, January 1997.

Carter, L.F., 1997, Water-quality assessment of the Rio Grande Valley study unit, Colorado, New Mexico, and Texas--Organic compounds and trace elements in bed sediment and fish tissue, 1992-93: U.S. Geological Survey Water-Resources Investigations Report 97-4002, $23 \mathrm{p}$.

Crowfoot, R.M., Ugland, R.C., Maura, W.S., Steger, R.D., and O'Neill, G.B., 1996, Water resources data, Colorado, water year 1995, Volume 1. Missouri River Basin, Arkansas River Basin, and Rio Grande Basin: U.S. Geological Survey Water-Data Report CO-95-1, $506 \mathrm{p}$. 
Cruz, R.R.. DeWees, R.K.. Funderburg, R.L., Lepp, R.L., Ortiz, David, and Shaull. D.A., 1994. Water resources data, New Mexico, water year 1993: U.S. Geological Survey Water-Data Report NM-93-1, 613 p.

Dane, C.H., and Bachman, G.O., 1965, Geologic map of New Mexico: U.S. Geological Survey, 2 sheets, scale 1:500,000.

Elfrink, L.H., Demlo, R.E., and Parsons, L.F., 1989, San Luis Valley Project, Closed Basin Division, Colorado, in Water in the valley - A 1989 perspective of water supplies, issues, and solutions in the San Luis Valley, Colorado: Colorado Ground Water Association, p. 155164.

Ellis, S.R., Levings, G.W., Carter, L.F., Richey, S.F., and Radell, M.J., 1993, Rio Grande Valley, Colorado, New Mexico, and Texas: Water Resources Bulletin, v. 29, no. 4, p. 617-646.

Faires, L.M., 1993, Methods of analyses by the U.S. Geological Survey National Water Quality Laboratory--Determination of metals in water by inductively coupled plasina--Mass spectrometry: U.S. Geological Survey Open-File Report 92-634, 28 p.

Fenneman, N.M., 1931, Physiography of Western United States: New York, McGraw-Hill Book Co., 534 p.

Ficke, J.F., and Hawkinson, R.D., 1975, The National Stream Quality Accounting Network (NASQAN)-Some questions and answers: U.S. Geological Survey Circular 719.23 p.

Fishman, M.J., and Friedman, L.C., eds., 1989, Methods for the determination of inorganic substances in water and fluvial sediments: U.S. Geological Survey Techniques of Water-Resources Investigations, book 5, chap. Al, $545 \mathrm{p}$.

Gilliom, R.J., Alley, W.M., and Gurtz, M.E., 1995, Design of the National Water-Quality Assessment Program-Occurrence and distribution of water-quality conditions: U.S. Geological Survey Circular 1112,33 p.

Gilliom, R.J., and Helsel, D.R., 1986, Estimation of distributional parameters for trace level water quality data, 1. Estimation techniques: Water Resources Research, v. 22, no. 2, p. 135-146.

Guy, H.P., 1969, Laboratory theory and methods for sediment analysis: U.S. Geological Survey Techniques of Water-Resources Investigations, book 5, chap. $\mathrm{Cl}$, $58 \mathrm{p}$.

Healy, D.F., 1996, Water-quality assessment of the Rio Grande Valley, Colorado, New Mexico, and Texas-Ocurrence and distribution of selected pesticides and nutrients at selected surface-water sites in the Mesilla Valley, 1994-95: U.S. Geological Survey WaterResources Investigations Report 96-4069, 85 p.

Helsel, D.R., and Hirsch, R.M., 1992, Statistical methods in water resources: Amsterdam, The Netherlands, Elsvier Science Publishers, 449 p., 4 app.
Hem, J.D., 1985, Study and interpretation of the chemical characteristics of natural water ( $3 \mathrm{~d}$ ed.): U.S. Geological Survey Water-Supply Paper 2254, $263 \mathrm{p}$.

Kennedy, E.J., 1984, Discharge ratings at gaging stations: U.S. Geological Survey Techniques of Water-Resources Investigations, book 3, chap. A 10,59 p.

Kennedy, V.C., Jones, B.F., and Zellweger, G.W., 1974. Filter pore-size effects on the analysis of $\mathrm{Al}, \mathrm{Fe}, \mathrm{Mn}$. and $\mathrm{Ti}$ in water: Water Resources Research, v. 10, p. 785-790.

Kilpatrick, F.A., and Schneider, V.R., 1983, Use of flumes in measuring discharge: U.S. Geological Survey Techniques of Water-Resources Investigations, book 3. chap. A14, $46 \mathrm{p}$.

Lindley, C.E., Stewart, J.T., and Sandstrom, M.W.. 1996, Determination of low concentrations of acetochlor in water by automated solid-phase extraction and gas chromatography with mass-selective detection: Journal of AOAC International, v. 79, no. 4, p. 962-966.

Livingston. R.K.. 1995, U.S. Geological Survey activities in New Mexico: U.S. Geological Survey Open-File Report 95-314, $21 \mathrm{p}$.

National Atmospheric Deposition Program, 1996, 1sopleth maps: National Atmospheric Deposition Program/National Trends Network home page [URL: http://nadp.nrel.colostate.edu/NADP/home_page.html]

Omernick, J.M., 1987, Aquatic ecoregions of the conterminous United States: Annals of the Association of American Geographers, v. 77, p. 118-125.

Ortiz, David, and Lange, K.M., 1996, Water resources data, New Mexico, water year 1995: U.S. Geological Survey Water-Data Report NM-95-1, 629 p.

Ott, Lyman, 1993, An introduction to statistical methods and data analysis (4th ed.): Belmont, Calif., Duxbury Press. 1051 p., 2 app.

Shelton, L.R., 1994, Field guide for collecting and processing stream-water samples for the National Water-Quality Assessment Program: U.S. Geological Survey Open-File Report 94-455, $42 \mathrm{p}$.

Siebenthal, C.E., 1910, Geology and water resources of the San Luis Valley, Colorado: U.S. Geological Survey WaterSupply Paper 240, $228 \mathrm{p}$.

Timme, P.J., 1995, National Water Quality Laboratory 1995 services catalog: U.S. Geological Survey Open-File Report 95-352, $120 \mathrm{p}$.

Tweto, Ogden, 1979, Geologic map of Colorado: U.S. Geological Survey, I sheet, scale 1:500,000.

Ugland, R.C., Cochran, B.J., Hiner, M.M., and Steger, R.D., 1994, Water resources data, Colorado, water year 1993, Volume 1. Missouri River Basin, Arkansas River Basin, and Rio Grande Basin: U.S. Geological Survey WaterData Report CO-93-1, 518 p. 
Ugland, R.C., Maura. W.S., Steger, R.D., and O'Neill, G.B., 1995. Water resources data. Colorado, water year 1994, Volume 1. Missouri River Basin. Arkansas River Basin. and Rio Grande Basin: U.S. Geological Survey WaterData Report CO-94-1, 418 p.

U.S. Environmental Protection Agency, 1997, STORET [URL: http://www.epa.gov/OWOW/STORET].

U.S. Geological Survey, 1986, Land use and land cover data from 1:250,000- and 1:100,000-scale maps: National Mapping Program, technical instructions, data user's guide 4, $36 \mathrm{p}$.

_ 1995, Programs in New Mexico: U.S. Geological Survey Fact Sheet FS-031-95, 4 p.

1997, Water-Data Storage and Retrieval System (WATSTORE) [URL:

http://water.usgs.gov/public/nawdex/wats/intro.html].

Werner, S.L., Burkhardt, M.R., and DeRusseau, S.N., 1996, Methods of analysis by the U.S. Geological Survey National Water Quality Laboratory--Determination of pesticides in water by Carbopak-B solid-phase extraction and high performance liquid chromatography: U.S. Geological Survey Open-File Report 96-216, $42 \mathrm{p}$.

Wershaw, R.L., Fishman, M.J., Grabbe, R.R., and Lowe, L.E., eds., 1987. Methods for the determination of organic substances in water and fluvial sediments: U.S. Geological Survey Techniques of Water-Resources Investigations, book 5, chap. A3, $80 \mathrm{p}$.

Winograd, I.J., 1959, Ground-water conditions and geology of Sunshine Valley and western Taos County, New Mexico: New Mexico State Engineer Technical Report $12,70 \mathrm{p}$.

Zaugg, S.D., Sandstrom. M.W., Smith, S.G., and Fehlberg, K.M., 1995, Methods of analysis by the U.S.

Geological Survey National Water Quality

Laboratory--Determination of pesticides in water by C-18 solid-phase extraction and capillary-column gas chromatography/mass spectrometry with selected ion monitoring: U.S. Geological Survey Open-File Report 95-181, p. 54. 